\title{
Lusioersily
}

\section{Solar disinfection is an augmentable, in situ-generated photo-Fenton reaction-Part 1: A review of the mechanisms and the fundamental aspects of the process}

Giannakis, S., Polo López, M. I., Spuhler, D., Sánchez Pérez, J. A., Fernandez-lbanez, P., \& Pulgarin, C. (2016). Solar disinfection is an augmentable, in situ-generated photo-Fenton reaction-Part 1: A review of the mechanisms and the fundamental aspects of the process. Applied Catalysis B: Environmental, 199, 199-223. https://doi.org/10.1016/j.apcatb.2016.06.009

Link to publication record in Ulster University Research Portal

Published in:

Applied Catalysis B: Environmental

Publication Status:

Published (in print/issue): 15/12/2016

DOI:

10.1016/j.apcatb.2016.06.009

\section{Document Version}

Author Accepted version

\section{General rights}

Copyright for the publications made accessible via Ulster University's Research Portal is retained by the author(s) and / or other copyright owners and it is a condition of accessing these publications that users recognise and abide by the legal requirements associated with these rights.

\section{Take down policy}

The Research Portal is Ulster University's institutional repository that provides access to Ulster's research outputs. Every effort has been made to ensure that content in the Research Portal does not infringe any person's rights, or applicable UK laws. If you discover content in the Research Portal that you believe breaches copyright or violates any law, please contact pure-support@ulster.ac.uk. 


\section{reaction-Part 1: A review of the mechanisms and the fundamental}

\section{aspects of the process}

4

5 Stefanos Giannakis ${ }^{a}$, María Inmaculada Polo López ${ }^{b, c}$, Dorothee Spuhler ${ }^{a}$, Jose Antonio Sánchez Pérez ${ }^{c}$, Pilar Fernández Ibáñez ${ }^{\mathrm{b}, \mathrm{c}, * *}$, César Pulgarin ${ }^{\mathrm{a}, *}$

7

a Swiss Federal Institute of Technology, Lausanne, Institute of Chemical Sciences and Engineering, 91015 Lausanne, Switzerland

b Plataforma Solar de Almería - CIEMAT, P.O. Box 22, 04200 Tabernas, Almería, Spain

${ }^{c}$ CIESOL, Joint Centre of the University of Almería-CIEMAT, 04120 Almería, Spain

*Corresponding author: Prof. Dr. César Pulgarin, E-mail: cesar.pulgarin@epfl.ch

**Corresponding author: Dr. Pilar Fernández Ibáñez, E-mail: pilar.fernandez@psa.es

Abstract

The present manuscript is a conceptual review concerning the photo-Fenton reaction at near-neutral $\mathrm{pH}$, used for bacterial inactivation. In this first Part, an overview of the mechanisms involved, as well as the fundamental concepts governing the near-neutral photo-Fenton reaction are critically assessed. The two constituents of the process, namely solar light and the Fenton reagents, are dissociated, with their direct and indirect actions thoroughly analyzed. The effects of UVB and UVA on the bacterial cell are firstly discussed, followed by the presentation of the indirect oxidative stress-related inactivation mechanisms initiated into the microorganism, in presence of light. Afterwards, the effect of each Fenton reagent $(\mathrm{H} 2 \mathrm{O} 2$, $\mathrm{Fe})$ is analyzed in a step-wise manner, with $\mathrm{H} 2 \mathrm{O} 2$ and $\mathrm{Fe}$ as enhancements of the solar disinfection mode of action. This approach proves that in fact, the solar photo-Fenton reaction is an enhanced solar disinfection process. Finally, the photo-Fenton reaction is put into context by considering the possible interactions of the separate parts of the combined process with the constituents of the natural environment that can play an important role in the evolution of the bacterial inactivation.

Keywords: solar disinfection; near-neutral photo-Fenton; light-bacteria interaction; mechanisms; photo-chemistry; photo-biology 


\section{Abbreviations}

35 AOP - Advanced Oxidation Process, ATP - Adenosine Triphosphate, CAT - Catalase, CDOM 36 Chromoforic Dissolved Organic Matter, CPC - Compound Parabolic Collector, CPD - Cyclobutane 37 Pyrimidine Dimers, DHAD - Dihydroxyacid Dehydratase, DNA - Deoxyribonucleic Acid, ESR - Electron 38 Spin Resonance, FADH2 - Flavin Adenine Dinucleotide, LMCT - Ligand to Metal Charge Transfer, MDA 39 - Malonaldehyde, NADH - Nicotinamide Adenine Dinucleotide, NER - Nucleotide Excision Repair, 40 NOM - Natural Organic Matter, PET - Polyethylene Tetrapthalate, POM - Particulate Organic Matter, 41 PP - Photoproduct, ROS - Reactive Oxygen Species, SOD - Superoxide Dismutase, SODIS - Solar Disinfection, tRNA - transfer ribonucleic acid, UV - Ultraviolet (light), Vis - Visible (light). 


\section{Table of Contents}

44

Abbreviations 2

Introduction. 5

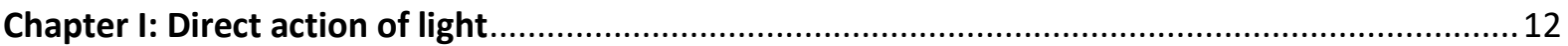

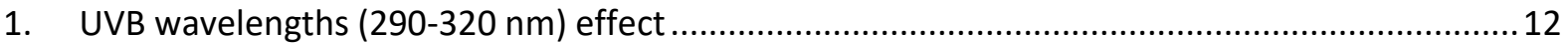

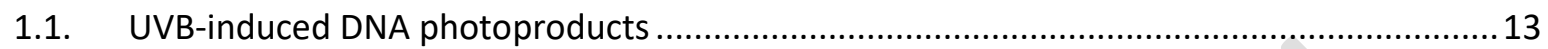

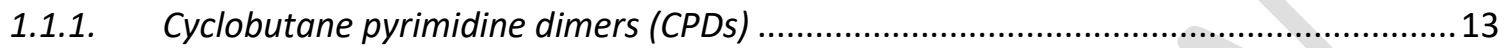

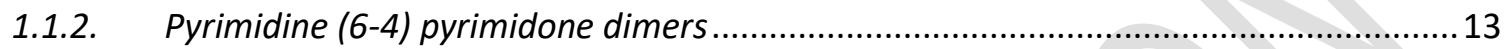

1.1.3. Monomeric pyrimidine (cytosine) photoproducts ...................................................... 13

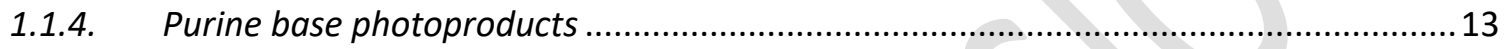

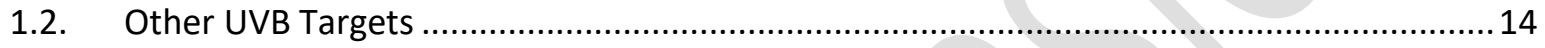

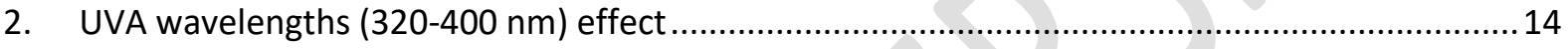

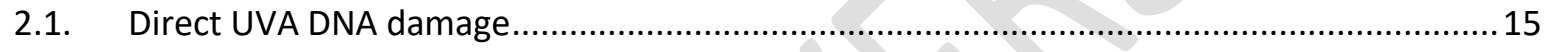

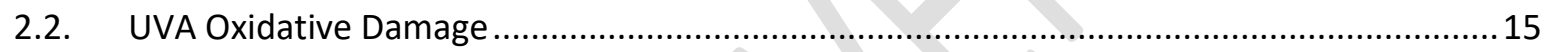

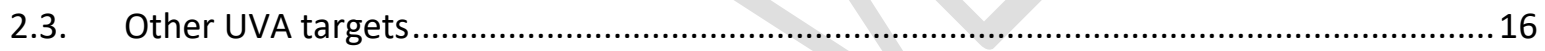

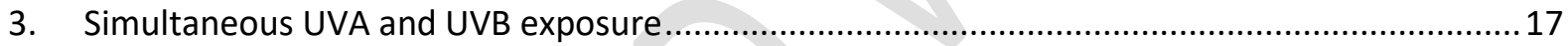

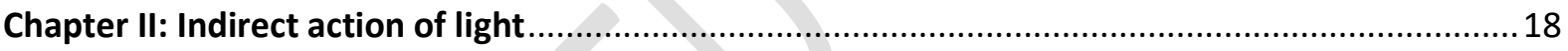

1. Indirect inactivation mechanisms: UVB or UVA-initiated, iron release - ROS generation and

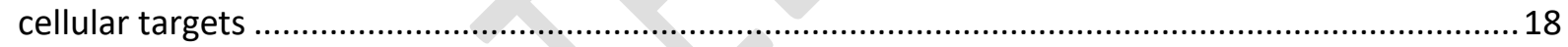

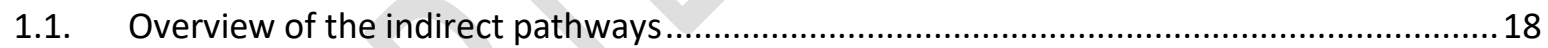

1.2. Reactive Oxygen Species (ROS) as a part of the cell life cycle .............................................20

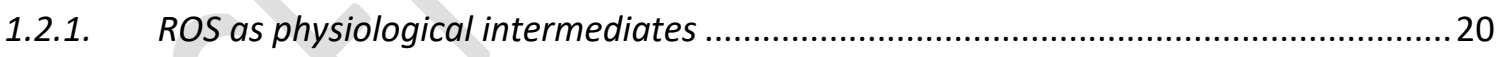

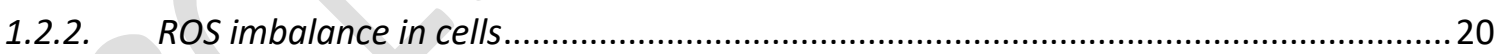

1.3. The significance of the internal Fenton process: iron release and facilitation......................22

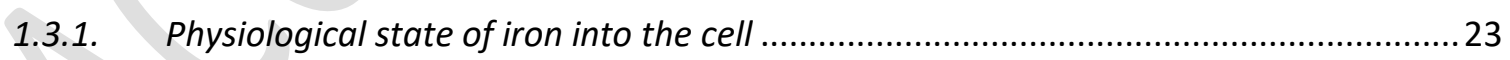

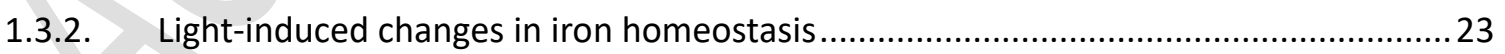

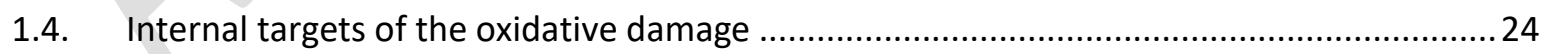

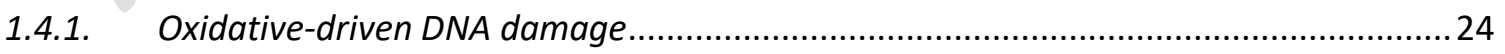

1.4.2. Other cellular targets (proteins, lipids, membranes, Fe/S clusters) ..............................26

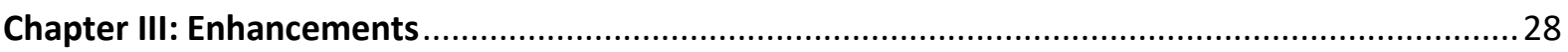

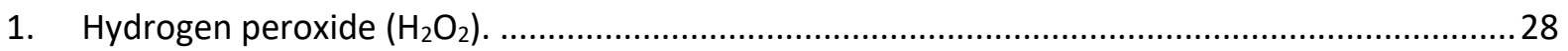

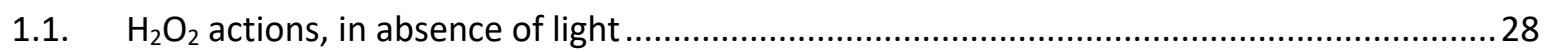

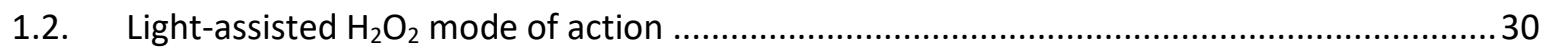

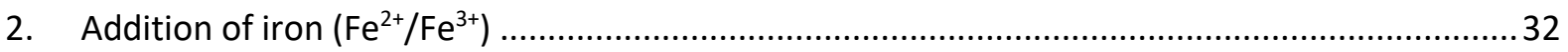


2.1. Iron as the Fenton reaction catalyst.

2.2. Influence of the matrix $\mathrm{pH}$.....

2.3. Iron Oxides: Formation and basic properties

2.4. Iron, light supply and bacterial presence facilitate the photo-Fenton reaction

2.5. Homogeneous and heterogeneous Fenton, photo-Fenton and semiconductor action mode,

1. Influence of natural organic matter on the photo-Fenton reaction.

1.2. DOM functions in natural waters. .50

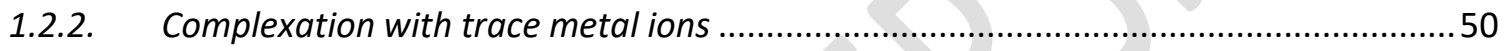


The year 1894 marked a new era in chemistry, with the postulation of the so-called Fenton reaction, named by H.J.H. Fenton himself. Although accidentally, it was found that iron ions, when combined with oxidizing agents, resulted in a solution with higher oxidative capacities than its original counterparts. The first "application" was the mix of hydrogen peroxide, tartaric acid, a base and iron (II) salt [1]. The identification of this finding marked the "Fenton reaction" or "Fenton reagent and the first full publication which he authored indicated the principles of what we refer today as Fenton chemistry [2]:

1) The use of an oxidant,

2) a metal in its reduced form and

3) the involvement of higher oxidation state of the used metal.

Although the initial formulation involved the application of iron (II) and $\mathrm{H}_{2} \mathrm{O}_{2}$ or hypochlorous acid, nowadays, we know that many metals can be used to facilitate the reaction, such as $\mathrm{Cu}, \mathrm{Cr}, \mathrm{V}, \mathrm{Ni}$, and the $\mathrm{H}_{2} \mathrm{O}_{2}$ can be replaced by chlorine water or $\mathrm{CaO}_{2}[1,3-5]$.

Fenton himself continued his research using this reaction for the synthesis of hydroxylated compounds. The years that followed were governed by controversy on the action mode of this reaction, such as Bray and Gorin [6] who proposed the involvement of ferryl species [Fe(IV)O $]^{2+}$ or the proposal of Haber and Weiss [7], who proposed the one-electron oxidation of $\mathrm{H}_{2} \mathrm{O}_{2}$, and other investigators [8] who suggested that the free radical mechanism is not plausible, but other intermediates are involved.

The progress continued with additions (from Baxendale et al. and Barb et al.) [9, 10] and better understanding of the process led to the application of treatment of various effluents from industrial activities. Walling contributed significantly to the understanding of the process against pollutants [11$16]$, but the treatment of microorganisms was still out of question. No one could imagine that the massive wastewater flows could be acidified for disinfection of microorganisms. Nevertheless, investigators such as Irwin Fridovich and James Imlay, have contextualized the Fenton reaction and its significance to biological systems (e.g. Imlay et al.) [17], and the first notions of its importance have been made. 100 years after the discovery, unanimity prevailed over the importance of the Fenton reaction in chemical and biological concepts. 
The final era in photo-Fenton started during the 90 's, when the first trials in higher pH were initiated

130 [18], and the contextualization assays of the photo-Fenton reaction were set-up [19-21]. The first

131

132

133

134

135

136

137

138

139

140

141

142

143

144

145

146

147

148

149 effort to inactivate microorganisms with iron complexes was made by Cho et al., [22] and the first actual near-neutral photo-Fenton reaction for microorganisms' inactivation was performed by Rincon and Pulgarin two years later [23]. The enhancing effect of the photo-Fenton process for E. coli inactivation in drinking water was for the first time reported, opening the way for new research directions; the near-neutral photo-Fenton works targeting various microbiological pollutants are presented in Table 1. These past 10 years, until now, have witnessed numerous works in microcontaminant and microbiological pollutant elimination.

In this review, we present a holistic approach in the (solar) photo-Fenton-driven inactivation of bacteria, and move from the entirely internal processes towards the external events that take place in aqueous media. More specifically, we begin with the direct effects of light on microorganisms, on their vital components, separating the direct (Chapter I) and the indirect actions of light (Chapter II). A conceptual review of the various actions, focusing on the photo-biological aspects is performed. As the photo-Fenton process is a synergetic sum of different parts based on light exposure, it is in fact a solar disinfection which can be enhanced (Chapter III), either by $\mathrm{H}_{2} \mathrm{O}_{2}$, by iron, or both simultaneously; the effects of each process are deeply discussed. The final chapter (Chapter IV), deals with the basic interactions of the aqueous media in which solar photo-Fenton may take place. Critical points and details on the effects that simultaneously occur, and elucidation of the process in a high degree is provided to the reader.

Table 1 - Chronological review of the works on near-neutral photo-Fenton inactivation of microorganisms.

\begin{tabular}{|c|c|c|c|}
\hline Authors & Year & Reference & Topic \\
\hline Cho et al. & 2004 & [22] & $\begin{array}{l}\text { Inactivation of Escherichia coli by photochemical reaction } \\
\text { of ferrioxalate at slightly acidic and near-neutral pHs }\end{array}$ \\
\hline $\begin{array}{l}\text { Rincon and } \\
\text { Pulgarin }\end{array}$ & 2006 & [23] & $\begin{array}{l}\text { Comparative evaluation of } \mathrm{Fe}^{3+} \text { and } \mathrm{TiO}_{2} \text { photoassisted } \\
\text { processes in solar photocatalytic disinfection of water }\end{array}$ \\
\hline $\begin{array}{c}\text { Rincon and } \\
\text { Pulgarin }\end{array}$ & $2007 a$ & [24] & $\begin{array}{c}\text { Absence of E. coli regrowth after } \mathrm{Fe}^{3+} \text { and } \mathrm{TiO}_{2} \text { solar } \\
\text { photoassisted disinfection of water in } \mathrm{CPC} \text { solar } \\
\text { photoreactor }\end{array}$ \\
\hline $\begin{array}{c}\text { Rincon and } \\
\text { Pulgarin }\end{array}$ & $2007 b$ & [25] & $\begin{array}{l}\mathrm{Fe}^{3+} \text { and } \mathrm{TiO}_{2} \text { solar-light-assisted inactivation of } E \text {. coli at } \\
\text { field scale }\end{array}$ \\
\hline
\end{tabular}




\begin{tabular}{|c|c|c|c|}
\hline $\begin{array}{l}\text { Moncayo- } \\
\text { Lasso et al. }\end{array}$ & 2008 & {$[26]$} & $\begin{array}{c}\text { Bacterial inactivation and organic oxidation via } \\
\text { immobilized photo-Fenton reagent on structured silica } \\
\text { surfaces }\end{array}$ \\
\hline $\begin{array}{l}\text { Moncayo- } \\
\text { Lasso et al. }\end{array}$ & 2009 & {$[27]$} & $\begin{array}{l}\text { Simultaneous } E \text {. coli inactivation and NOM degradation in } \\
\text { river water via photo-Fenton process at natural } \mathrm{pH} \text { in solar } \\
\mathrm{CPC} \text { reactor. A new way for enhancing solar disinfection of } \\
\text { natural water }\end{array}$ \\
\hline Kim et al. & 2010 & [28] & Inactivation of MS2 Coliphage by Fenton's reagent \\
\hline $\begin{array}{l}\text { Mazille et } \\
\text { al. }\end{array}$ & 2010 & [29] & $\begin{array}{l}\text { Comparative evaluation of polymer surface } \\
\text { functionalization techniques before iron oxide deposition. } \\
\text { Activity of the iron oxide-coated polymer films in the } \\
\text { photo-assisted degradation of organic pollutants and } \\
\text { inactivation of bacteria }\end{array}$ \\
\hline $\begin{array}{l}\text { Sciacca et } \\
\text { al. }\end{array}$ & 2010 & {$[30]$} & $\begin{array}{l}\text { Dramatic enhancement of solar disinfection (SODIS) of } \\
\text { wild Salmonella sp. in PET bottles by } \mathrm{H}_{2} \mathrm{O}_{2} \text { addition on } \\
\text { natural water of Burkina Faso containing dissolved iron }\end{array}$ \\
\hline $\begin{array}{l}\text { Spuhler et } \\
\text { al. }\end{array}$ & 2010 & {$[31]$} & $\begin{array}{l}\text { The effect of } \mathrm{Fe}^{2+}, \mathrm{Fe}^{3+}, \mathrm{H}_{2} \mathrm{O}_{2} \text { and the photo-Fenton reagent } \\
\text { at near neutral pH on the solar disinfection (SODIS) at low } \\
\text { temperatures of water containing Escherichia coli K12 }\end{array}$ \\
\hline $\begin{array}{l}\text { Nieto-Juarez } \\
\text { et al. }\end{array}$ & 2010 & [32] & $\begin{array}{l}\text { Inactivation of MS2 coliphage in Fenton and Fenton-like } \\
\text { systems: role of transition metals, hydrogen peroxide and } \\
\text { sunlight }\end{array}$ \\
\hline $\begin{array}{l}\text { Sciacca et } \\
\text { al. }\end{array}$ & 2011 & [33] & $\begin{array}{l}\text { Solar disinfection of wild Salmonella sp. in natural water } \\
\text { with a } 18 \mathrm{~L} \text { CPC photoreactor: Detrimental effect of non- } \\
\text { sterile storage of treated water }\end{array}$ \\
\hline $\begin{array}{l}\text { Bandala et } \\
\text { al. }\end{array}$ & 2011 & [34] & $\begin{array}{l}\text { Application of azo dyes as dosimetric indicators for } \\
\text { enhanced photocatalytic solar disinfection (ENPHOSODIS) }\end{array}$ \\
\hline $\begin{array}{l}\text { Bernabeu et } \\
\text { al. }\end{array}$ & 2011 & {$[35]$} & $\begin{array}{c}\text { Exploring the applicability of solar driven photocatalytic } \\
\text { processes to control infestation by zebra mussel }\end{array}$ \\
\hline $\begin{array}{l}\text { Ortega- } \\
\text { Gomez et al. }\end{array}$ & 2012 & {$[36]$} & $\begin{array}{l}\text { Water disinfection using photo-Fenton: Effect of } \\
\text { temperature on Enterococcus faecalis survival }\end{array}$ \\
\hline $\begin{array}{l}\text { Moncayo- } \\
\text { Lasso et al. }\end{array}$ & 2012 & [37] & $\begin{array}{l}\text { The detrimental influence of bacteria (E. coli, Shigella and } \\
\text { Salmonella) on the degradation of organic compounds }\end{array}$ \\
\hline
\end{tabular}




\begin{tabular}{|c|c|c|c|}
\hline & & & $\begin{array}{l}\text { (and vice versa) in } \mathrm{TiO}_{2} \text { photocatalysis and near-neutral } \\
\text { photo-Fenton processes under simulated solar light. }\end{array}$ \\
\hline $\begin{array}{l}\text { Polo-Lopez } \\
\text { et al. }\end{array}$ & 2012 & [38] & $\begin{array}{l}\text { Mild solar photo-Fenton: An effective tool for the removal } \\
\text { of Fusarium from simulated municipal effluents }\end{array}$ \\
\hline $\begin{array}{l}\text { Klamerth et } \\
\text { al. }\end{array}$ & 2012 & [39] & $\begin{array}{l}\text { Treatment of Municipal Wastewater Treatment Plant } \\
\text { Effluents with Modified Photo-Fenton As a Tertiary } \\
\text { Treatment for the Degradation of Micro Pollutants and } \\
\text { Disinfection }\end{array}$ \\
\hline $\begin{array}{l}\text { Garcia- } \\
\text { Fernandez } \\
\text { et al. }\end{array}$ & 2012 & [40] & $\begin{array}{l}\text { Bacteria and fungi inactivation using } \mathrm{Fe}^{3+} / \text { sunlight, } \\
\mathrm{H}_{2} \mathrm{O}_{2} / \text { sunlight and near neutral photo-Fenton: A } \\
\text { comparative study }\end{array}$ \\
\hline $\begin{array}{l}\text { Bandala et } \\
\text { al. }\end{array}$ & 2012 & {$[41]$} & $\begin{array}{c}\text { Inactivation of Ascaris eggs in water using sequential solar } \\
\text { driven photo-Fenton and free chlorine }\end{array}$ \\
\hline $\begin{array}{l}\text { Rodriguez- } \\
\text { Chueca et } \\
\quad \text { al. }\end{array}$ & 2013 & {$[42]$} & $\begin{array}{c}\text { Inactivation of Enterococcus faecalis, Pseudomonas } \\
\text { aeruginosa and Escherichia coli present in treated urban } \\
\text { wastewater by coagulation-flocculation and photo-Fenton } \\
\text { processes }\end{array}$ \\
\hline $\begin{array}{l}\text { Ortega- } \\
\text { Gómez et al. }\end{array}$ & 2013 & {[]$_{3}$} & $\begin{array}{c}\text { Inactivation of Enterococcus faecalis in simulated } \\
\text { wastewater treatment plant effluent by solar photo- } \\
\text { Fenton at initial neutral pH }\end{array}$ \\
\hline $\begin{array}{l}\text { Nieto-Juarez } \\
\text { and Kohn }\end{array}$ & 2013 & [44] & $\begin{array}{l}\text { Virus removal and inactivation by iron (hydr)oxide- } \\
\text { mediated Fenton-like processes under sunlight and in the } \\
\text { dark }\end{array}$ \\
\hline $\begin{array}{l}\text { Ndounla et } \\
\text { al. }\end{array}$ & 2013 & {$[45]$} & $\begin{array}{l}\text { Inactivation by solar photo-Fenton in PET bottles of wild } \\
\text { enteric bacteria of natural well water: Absence of re- } \\
\text { growth after one week of subsequent storage. }\end{array}$ \\
\hline $\begin{array}{l}\text { Agulló- } \\
\text { Barceló et } \\
\text { al. }\end{array}$ & 2013 & {$[46]$} & $\begin{array}{c}\text { Solar Advanced Oxidation Processes as disinfection tertiary } \\
\text { treatments for real wastewater: Implications for water } \\
\text { reclamation }\end{array}$ \\
\hline Rubio et al. & 2013 & [47] & $\begin{array}{l}\text { Comparative effect of simulated solar light, } \mathrm{UV}, \mathrm{UV} / \mathrm{H}_{2} \mathrm{O}_{2} \\
\left.\text { and photo-Fenton treatment (UV-Vis } / \mathrm{H}_{2} \mathrm{O}_{2} / \mathrm{Fe}^{2+},{ }^{+}\right) \text {in the } \\
\text { Escherichia coli inactivation in artificial seawater }\end{array}$ \\
\hline
\end{tabular}




\begin{tabular}{|c|c|c|c|}
\hline $\begin{array}{l}\text { Polo-Lopez } \\
\text { et al. }\end{array}$ & 2013 & [48] & $\begin{array}{l}\text { Benefits of photo-Fenton at low concentrations for solar } \\
\text { disinfection of distilled water. A case study: Phytophthora } \\
\text { capsici }\end{array}$ \\
\hline $\begin{array}{l}\text { Ruales- } \\
\text { Lonfat et al. }\end{array}$ & $2014 a$ & [49] & $\begin{array}{l}\text { Iron-catalyzed low cost solar activated process for drinking } \\
\text { water disinfection in Colombian rural areas }\end{array}$ \\
\hline $\begin{array}{l}\text { Ruales- } \\
\text { Lonfat et al. }\end{array}$ & $2014 b$ & [50] & $\begin{array}{l}\text { Deleterious effect of homogeneous and heterogeneous } \\
\text { near-neutral photo-Fenton system on Escherichia coli. } \\
\text { Comparison with photo-catalytic action of } \mathrm{TiO}_{2} \text { during cell } \\
\text { envelope disruption }\end{array}$ \\
\hline $\begin{array}{l}\text { Ndounla et } \\
\text { al. }\end{array}$ & $2014 a$ & [51] & $\begin{array}{l}\text { Evaluation of the efficiency of the photo Fenton } \\
\text { disinfection of natural drinking water source during the } \\
\text { rainy season in the Sahelian region }\end{array}$ \\
\hline $\begin{array}{l}\text { Ndounla et } \\
\text { al. }\end{array}$ & $2014 b$ & [52] & $\begin{array}{l}\text { Relevant impact of irradiance (vs. dose) and evolution of } \\
\mathrm{pH} \text { and mineral nitrogen compounds during natural water } \\
\text { disinfection by photo-Fenton in a solar CPC reactor. }\end{array}$ \\
\hline $\begin{array}{l}\text { Ortega- } \\
\text { Gómez et al. }\end{array}$ & $2014 a$ & [53] & $\begin{array}{c}\text { Solar photo-Fenton for water disinfection: An investigation } \\
\text { of the competitive role of model organic matter for } \\
\text { oxidative species }\end{array}$ \\
\hline $\begin{array}{l}\text { Ortega- } \\
\text { Gómez et al. }\end{array}$ & $2014 b$ & [54] & $\begin{array}{l}\text { Inactivation of natural enteric bacteria in real municipal } \\
\text { wastewater by solar photo-Fenton at neutral pH }\end{array}$ \\
\hline $\begin{array}{l}\text { Teodoro et } \\
\text { al. }\end{array}$ & 2014 & [55] & $\begin{array}{l}\text { Disinfection of greywater pre-treated by constructed } \\
\text { wetlands using photo-Fenton: Influence of } \mathrm{pH} \text { on the } \\
\text { decay of Pseudomonas aeruginosa }\end{array}$ \\
\hline $\begin{array}{l}\text { Rodríguez- } \\
\text { Chueca et } \\
\text { al. }\end{array}$ & $2014 a$ & [56] & $\begin{array}{l}\text { Disinfection of wastewater effluents with the Fenton-like } \\
\text { process induced by electromagnetic fields }\end{array}$ \\
\hline $\begin{array}{l}\text { Rodríguez- } \\
\text { Chueca et } \\
\text { al. }\end{array}$ & $2014 b$ & [57] & $\begin{array}{l}\text { Disinfection of real and simulated urban wastewater } \\
\text { effluents using a mild solar photo-Fenton }\end{array}$ \\
\hline $\begin{array}{l}\text { Polo-Lopez } \\
\text { et al. }\end{array}$ & 2014 & [58] & $\begin{array}{c}\text { Assessment of solar photo-Fenton, photocatalysis, and } \\
\mathrm{H}_{2} \mathrm{O}_{2} \text { for removal of phytopathogen fungi spores in } \\
\text { synthetic and real effluents of urban wastewater }\end{array}$ \\
\hline
\end{tabular}




\begin{tabular}{|c|c|c|c|}
\hline $\begin{array}{l}\text { Ruales- } \\
\text { Lonfat et al. }\end{array}$ & 2015 & [59] & $\begin{array}{l}\text { Iron oxides semiconductors are efficients for solar water } \\
\text { disinfection: A comparison with photo-Fenton processes at } \\
\text { neutral pH }\end{array}$ \\
\hline $\begin{array}{l}\text { Giannakis et } \\
\text { al. }\end{array}$ & 2015 & {$[60]$} & $\begin{array}{l}\text { Ultrasound enhancement of near-neutral photo-Fenton for } \\
\text { effective E. coli inactivation in wastewater }\end{array}$ \\
\hline $\begin{array}{l}\text { Ortega- } \\
\text { Gómez et al. }\end{array}$ & 2015 & [61] & $\begin{array}{l}\text { Principal parameters affecting virus inactivation by the } \\
\text { solar photo-Fenton process at neutral } \mathrm{pH} \text { and } \mu \mathrm{M} \\
\text { concentrations of } \mathrm{H}_{2} \mathrm{O}_{2} \text { and } \mathrm{Fe}^{2+} \beta^{++} \text {. }\end{array}$ \\
\hline $\begin{array}{l}\text { Barreca et } \\
\qquad \text { al. }\end{array}$ & 2015 & [62] & $\begin{array}{l}\text { Escherichia coli inactivation by neutral solar } \\
\text { heterogeneous photo-Fenton (HPF) over hybrid } \\
\text { iron/montmorillonite/alginate beads }\end{array}$ \\
\hline Pulgarin C. & 2015 & [63] & $\begin{array}{l}\text { Fe vs. } \mathrm{TiO}_{2} \text { photo-assisted processes for enhancing the } \\
\text { solar inactivation of bacteria in water. }\end{array}$ \\
\hline $\begin{array}{l}\text { Ndounla } \\
\text { and Pulgarin }\end{array}$ & 2015 & [64] & $\begin{array}{l}\text { Solar light (hv) and } \mathrm{H}_{2} \mathrm{O}_{2} / \text { hv photo-disinfection of natural } \\
\text { alkaline water ( } \mathrm{pH} 8.6 \text { ) in a compound parabolic collector } \\
\text { at different day periods in Sahelian region }\end{array}$ \\
\hline $\begin{array}{l}\text { Rodríguez- } \\
\text { Chueca et } \\
\text { al. }\end{array}$ & $2015 a$ & [65] & $\begin{array}{l}\text { Kinetic modeling of Escherichia coli and Enterococcus sp. } \\
\text { inactivation in wastewater treatment by photo-Fenton and } \\
\qquad \mathrm{H}_{2} \mathrm{O}_{2} / \mathrm{UV} \text {-vis processes. }\end{array}$ \\
\hline $\begin{array}{l}\text { Rodríguez- } \\
\text { Chueca et } \\
\text { al. }\end{array}$ & $2015 b$ & [66] & $\begin{array}{c}\text { Conventional and Advanced Oxidation Processes Used in } \\
\text { Disinfection of Treated Urban Wastewater }\end{array}$ \\
\hline $\begin{array}{l}\text { Aurioles- } \\
\text { López et al. }\end{array}$ & 2015 & [67] & $\begin{array}{c}\text { Effect of iron salt counter ion in dose-response curves for } \\
\text { inactivation of Fusarium solani in water through solar } \\
\text { driven Fenton-like processes }\end{array}$ \\
\hline $\begin{array}{l}\text { Ruales- } \\
\text { Lonfat et al. }\end{array}$ & 2016 & [68] & $\begin{array}{l}\text { Bacterial inactivation with iron citrate complex: A new } \\
\text { source of dissolved iron in solar photo-Fenton process at } \\
\text { near-neutral and alkaline } \mathrm{pH}\end{array}$ \\
\hline $\begin{array}{l}\text { Ruiz-Aguirre } \\
\text { et al. }\end{array}$ & 2016 & [69] & $\begin{array}{l}\text { Assessing the validity of solar membrane distillation for } \\
\text { disinfection of contaminated water }\end{array}$ \\
\hline $\begin{array}{l}\text { Ortega- } \\
\text { Gómez et al. }\end{array}$ & 2016 & [70] & $\begin{array}{c}\text { Wastewater disinfection by neutral pH photo-Fenton: The } \\
\text { role of solar radiation intensity }\end{array}$ \\
\hline $\begin{array}{l}\text { Giannakis et } \\
\text { al. }\end{array}$ & $2016 a$ & [71] & $\begin{array}{l}\text { Castles fall from inside: Evidence for dominant internal } \\
\text { photo-catalytic mechanisms during treatment of }\end{array}$ \\
\hline
\end{tabular}




\begin{tabular}{|c|c|c|c|}
\hline & & & $\begin{array}{r}\text { Saccharomyces cerevisiae by photo-Fenton at near-neutral } \\
p H\end{array}$ \\
\hline $\begin{array}{c}\text { Giannakis et } \\
\text { al. }\end{array}$ & $2016 \mathrm{~b}$ & & $\begin{array}{r}\text { Simultaneous degradation of microorganisms and } \\
\text { micropollutants in wastewater by Advanced Oxidation } \\
\text { Processes (AOPs): influence of the secondary } \\
\text { (pre)treatment on bacterial inactivation and regrowth }\end{array}$ \\
\hline
\end{tabular}

151 


\section{Chapter I: Direct action of light}

The germicidal action of solar disinfection of drinking water is attributed to the wavelengths reaching the Earth's surface. Although UVC is absorbed during its passage through the atmosphere and is neglected, UVB is very often not taken into account, when the physical and microbiological aspects of the process are estimated. This strategy may be true for SODIS taking place in recipient vessels which filter UVB, but before its diminution due to length limitations, UVB affects significantly a considerable layer of the exposed natural water bodies, mainly resulting to mutations and possibly apoptosis and/or imminent cell death. The significance of this process has been long identified [72] and has influenced the design of solar disinfection units [73]; its germicidal effect is 100-1000 times more efficient against microbial inactivation than UVA. Hence, the first chapter of this review is dedicated to the biological effects of the direct UVB action on bacteria.

\section{The electromagnetic spectrum}

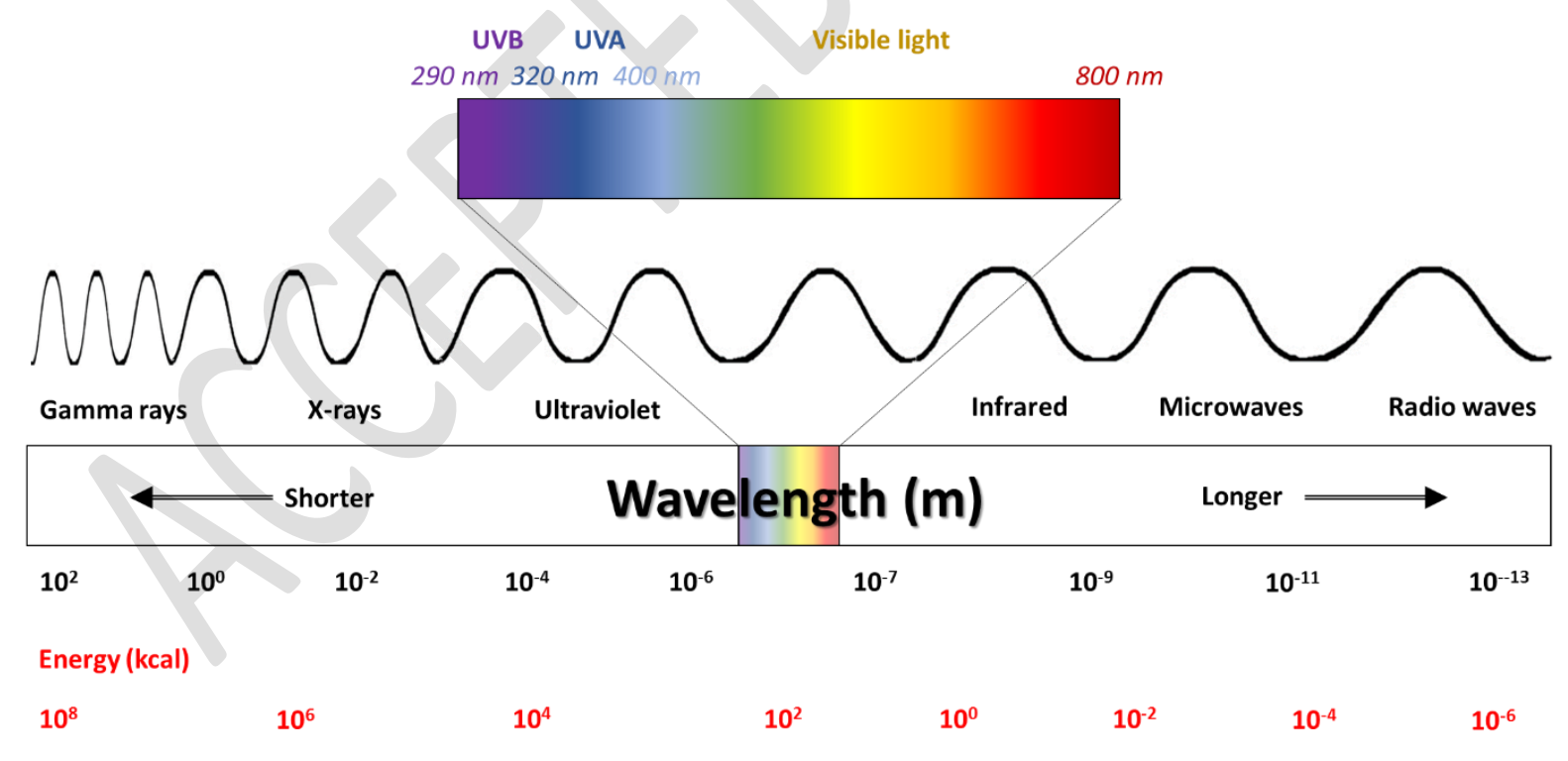

Figure 1 - The electromagnetic spectrum, with emphasis on the UV-visible light. The order of increasing

In principal UVB inflicts damages due to its absorbance by the various cellular components. More specifically, Bensasson et al., [74] offer an extensive review on the components directly damaged by 
171 UVB irradiation (for instance, chromophores like the heme groups, enzymes, vitamins, acids), with the 172 principal targets being the genetic material and the proteins. Other components such as lipids and 173 polysaccharides do not undergo direct damage, as their absorption in this light region is limited [75]. 174 Considering the affected entities, the damages will be separated in DNA photoproducts, targets of protein nature and iron bearing compounds. The further implications inflicted to the repair mechanisms will also be assessed.

\subsection{UVB-induced DNA photoproducts}

179 Commonly, the UVB wavelengths leads to the formation of same-strand photo-adducts among 180 nitrogen-containing bases [76-79], or even in double stranded DNA [80]. These photoproducts fall within the next categories [78]:

\subsubsection{Cyclobutane pyrimidine dimers (CPDs)}

Light excites pyrimidine bases in a triplet state, and then undergo a [2+2] addition of the $\mathrm{C} 5-\mathrm{C} 6$ bonds of consequent pyrimidine bases, forming the cis-syn cyclobutane pyrimidine dimers $(P<>P)[78]$. This process is very similar to the effects of shortwave UVC irradiation, being the most common photoproduct [81-84].

\subsubsection{Pyrimidine (6-4) pyrimidone dimers}

Under a different energetic transition than CPDs, a pyrimidine base is exited to singlet state and reacts with another pyrimidine base, by $[2+2]$ cycloaddition, forming the stable bonds, the pyrimidine (6-4) pyrimidone dimers $[78,81,84]$. The implications aggravate due to the shift of UV light absorption towards the long UV wavelengths, and the further absorption of UV (A or B) light converts these adducts into different isomers, the Dewar valence isomers $[85,86]$. These stereoisomers add to the existing problems of DNA replication.

\subsubsection{Monomeric pyrimidine (cytosine) photoproducts}

Light absorption from the monomeric cytosine compounds has been found to favor the excitation to its single state and a subsequent nucleophilic addition of water. The hydrated product "6-hydroxy-5,6dihydrocytosine" or cytosine photo-hydrate is formed [87].

\subsubsection{Purine base photoproducts}

Along with pyrimidine bases, purine bases share the characteristics of high UV light absorbance at 260 $\mathrm{nm}$, tailing up to the UVB region $[75,85]$. As a result, photo-damage is bound to take place. Dewar 
adducts in isolated DNA have been reported $[75,88]$ and at a smaller effect, damages include bistranded OxyPurine or abasic clusters, double strand breaks [89]. However the most common products are the $\mathrm{T}<>\mathrm{T}, \mathrm{T}<>\mathrm{C}$ and (6-4) $\mathrm{T}<>\mathrm{C}$ dimers [88].

\subsection{Other UVB Targets}

While the strand itself suffers from extensive photo-damage, there are more, also noteworthy candidates reported in literature, such as some proteins and their constituents and other more complex targets, such as enzymes and proteins. In principal, UVA light (above $320 \mathrm{~nm}$ ) is not absorbed by proteins without bound co-factors or groups, as they do not contain chromophoric compounds in this region [75, 90]; in the opposite case, i.e. UVB wavelengths, this is deemed possible. However, some amino acids, such as are tryptophan (Trp), tyrosine (Tyr), phenylalanine (Phe), histidine (His), cysteine (Cys) and cysteine residue, are reported to absorb UV light (for UV spectra, see Bensasson et al. [74]). The rest of the amino acids absorb mainly at $190 \mathrm{~nm}$, tailing up to $220 \mathrm{~nm}$, mostly due to the presence of the peptide bond [-C(O)-NH-]. Therefore, as UVC wavelengths are not present in the solar spectrum, it is concluded that the absorption by the backbone of the proteins is negligible [90]. Another target, which, as will be analyzed in next chapters, initiates indirect reactions is enterobactin. This powerful iron-chelating agent demonstrates peak absorbance at $316 \mathrm{~nm}$ [91]. This behavior suggests chromophoric abilities and the result is an increase of the internal iron concentration in the cell. Finally, as a result of the cell exposure to UVB light, depending on the damage levels on the genome, either apoptosis or repair can be initiated. The latter case can be demonstrated that cell death can be repealed by CPD restoration, by nucleotide excision repair (NER) [92, 93]. However, some of the proteins (Fpg, formamidopyrimidine-DNA glycosylase) responsible for DNA repair are suspected to be prone to UVB-induced alterations, ending up compromised [94].

\section{UVA wavelengths (320-400 $\mathrm{nm})$ effect}

As explained in the beginning, in the case SODIS is taking place in polyethylene terephthalate (PET) or plain glass bottles, UVA light is the principal wavelength region causing bacterial inactivation during solar exposure of water. Although differences can occur in the absorption wavelengths among the materials that carry the treated water, the largest fraction of these wavelengths will get transmitted; in PET or borosilicate bottles the absorption spectra differ in the near-UVB region, permitting a higher fraction in the latter case. In overall, the direct effects of UVA can be characterized as less harmful, 
compared with the rest of the UV light wavelengths, but the direct absorption by DNA, proteins and other structures is noteworthy $[75,78,95,96]$ and will be discussed in this part. The indirect pathways will be further analyzed in later stages of this review.

\subsection{Direct UVA DNA damage}

In an analogy with UVB light, UVA is responsible of inflicting a series of different types of damage on the DNA. The hypothesis on UVA-induced CPD formation $[83,97,98]$ were verified. Besaratinia et al. [99] proved that CPDs are also CPDs formed under UVA light, but in a different way than UVB [100]. It has been reported that the photo-products are strand breaks, oxidation of pyrimidines, purines (all analyzed afterwards) and CPDs [97] in a ratio of 1:1:3:10. According to the medium carrying the DNA, the degree of damage can differ; high CPD formation is induced in pure water [101]. In the same work, and other ones (for instance Mouret et al. [102]) the direct connection of UVA-and CPDs is verified. The wavelengths that can induce the CPD formation tail up to $365 \mathrm{~nm}$, both for isolated and cellular DNA [103-106], with simultaneous absence of (6-4) photo-products. Mainly, the dimerization took place among thymine bases at nearly $90 \%$ of the total dimers [102], through direct absorption of UVA light although initially a photo-sensitizer was thought to mediate [97]. Finally, the issue of the Dewar valence isomers is also attributed to UVA light absorption, as this photo-transformation peaks at around $320 \mathrm{~nm}$, border among UVA and UVB light [79]. Especially (6-4) PPs produced by UVB illumination will undergo UVA-mediated conversion to an isomer [85, 86, 97], if the light source emits both UVB and UVA wavelengths, such as sunlight $[79,107]$.

\subsection{UVA Oxidative Damage}

Although CPDs are formed in a higher ratio than the other products [97], UVA light is responsible for a series of other reactions, namely Type I and Type II photo-oxidation reactions $[78,108]$. Type I reactions are one-electron oxidation (or hydrogen atom abstraction) processes, and Type II are singlet oxygen $\left(\Delta g^{1} \mathrm{O}_{2}\right.$ or more simply $\left.{ }^{1} \mathrm{O}_{2}\right)$ ones $[75,78,109]$. In Type I reactions, DNA bases are the electron donors, and especially guanine, compared with thymine, adenine, cytosine and 5-methycytosine [78]. The result of this process is a large quantity of base (guanine) cations, possibly hydrated or deprotonated afterwards. However, the excitation by UVA light, in Type II reactions, singlet oxygen is involved, reacting with electron rich bases. As a result, singlet oxygen facilitates the energy transfer from guanine towards molecular oxygen $[78,110]$, also involving unstable stereoisomers among its C4 
and C8 carbon atoms $[78,111]$. However, since Type II reactions are oxygen-dependent, their main action is considered indirect and will be analyzed in next chapters.
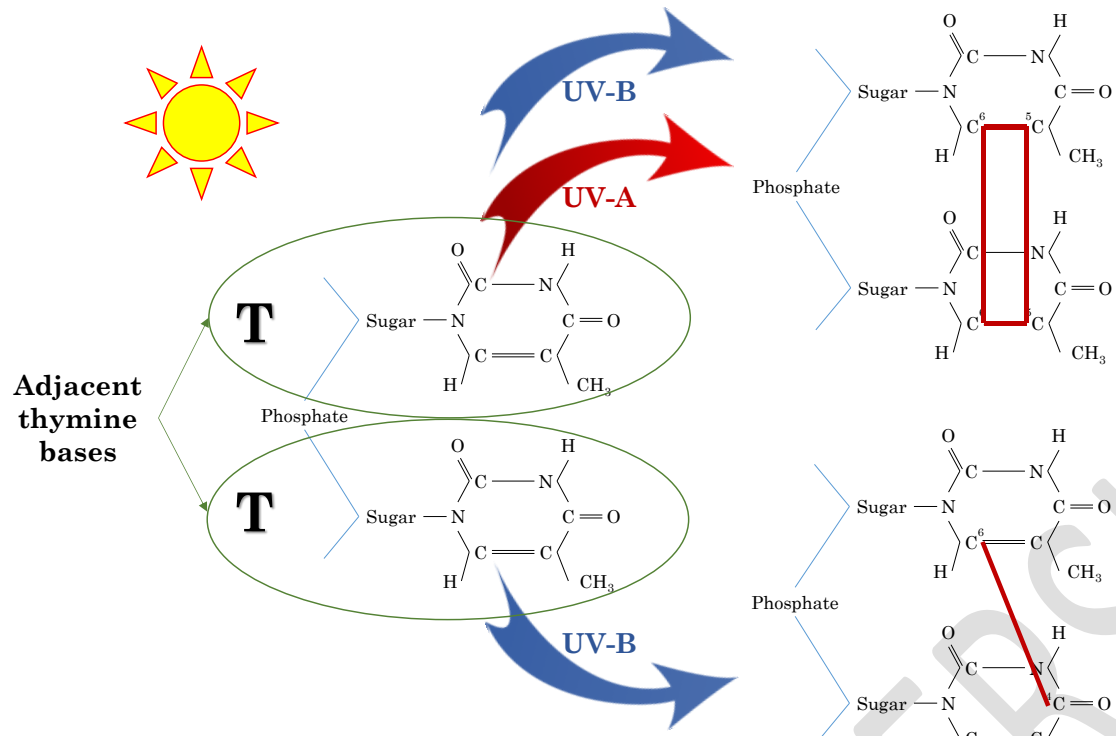

Cyclobutane pyrimidine dimer (CPD)

Pyrimidine (6-4) pyrimidinone

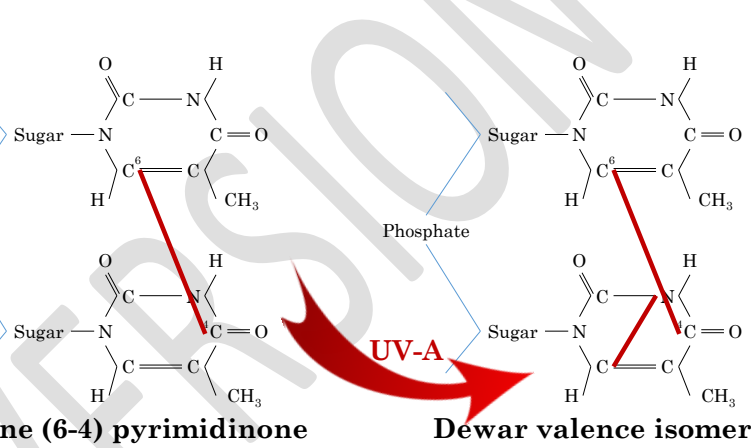

Dewar valence isomer

Figure 2 - Chemical structural modifications of the DNA during exposure to solar light (adapted from Batista et al.[100]). The exposure of thymine bases to light can induce the formation of CPDs and (6-4) PPs, while the existence of UVA can further inflict modifications in the structure of the chain, the Dewar valence isomers.

\subsection{Other UVA targets}

Apart from DNA, UVA light affects other compounds in the cell with significant biological effects. More specifically, compounds that participate in either the metabolic cycle or are vital for cell homeostasis exhibit UVA absorption. Catalase, for instance, is an enzyme which regulates the $\mathrm{H}_{2} \mathrm{O}_{2}$ concentration during the respiration process, and UVA light effects suggest peroxidase activity halting [91]. Dihydroxy acid dehydratase (DHAD) is one of the iron-sulfur containing molecules, which demonstrates photo-sensible behavior; although initially it was detectable, upon irradiation its function was suspended $[112,113]$. Its modification can initiate further indirect stresses; more details on the compounds that initiate indirect pathways of damage will be given in following chapters. Furthermore, the thiolated tRNA is a trigger molecule for environmental changes, which indicates possible stresses of near-UV nature [91]. Finally, ribonucleotide reductase, a key enzyme in metabolic cycles of living organisms, contains components which demonstrate strong absorption in the UV range and are likely to be affected [91]. 


\section{$2843 . \quad$ Simultaneous UVA and UVB exposure}

285 During simulated solar exposure, if both wavelength groups are transmitted effectively through the 286 medium, the DNA damage resembles mostly the pattern due to the UVB wavelengths [80]. After some 287 hours under simulated solar light, the analyses revealed undetectable levels of (6-4) photoproducts 288 [84]; therefore it was estimated that irradiation under simulated solar light inflicts 20 to 40 times more 289 CDPs than any other photoproducts $[83,84]$. Also, the contribution of UVA to thymine dimer 290 formation is not negligible, since it produces more thymine dimers, compared to UVB alone [75], in a 291 synergistic way. Finally, the visible light wavelengths alone, around 400-450 nm, yield damage to DNA, 292 repairable by the Fpg proteins, but the simultaneous emission of UVB, will hamper its capabilities 293 [114]. 


\section{Chapter II: Indirect action of light}

release - ROS generation and cellular targets

\subsection{Overview of the indirect pathways}

301

302

303

According to the previous chapter, the damage inflicted onto the cells and subsequently, the chain of events followed towards inactivation, can be separated in direct and indirect pathways. In this chapter, locating the indirect inactivation mechanisms is attempted, limited to the ones initiated by light but fulfilled with various intermediaries.

In overall, as far as UVB light is concerned, its main effect is the direct formation of photoproducts, as described before. However, there are important findings relating these wavelengths with initiation of secondary mechanisms, crucial to cell survival. In principal, UVB light and catalase are implicated in an unexpected inactivation pathway. First, UVB light is inflicted onto the cell. Direct actions aside, catalase is activated in a dual manner, protective or toxic [115], as follows: UVB light is absorbed by catalase and is converted to reactive chemical intermediates, in order to protect the DNA from the direct action against its bases [115]. These intermediates can be easily scavenged by the normal antioxidant enzymes [116], but under light stress, this possibility is jeopardized. The damage is heavily related to the presence of oxygen, indicating an indirect, ROS-related pathway of oxidative damage, thanks to protonation from water, against functional moieties of the cell [115]. In our opinion, this behavior confirms an early hypothesis that catalase is not the only, or a primary intracellular enzymatic defense mechanism against toxicity of UV light [117], but other mechanisms (such as the peroxidasesupported ones, or the light absorbance by pigments and similar substances) exist; further details on the oxidative protection ways will be given in the following chapters.

On the other hand, UVA wavelengths affect the DNA only in a limited extent and affect the overall functions of the cell on different levels. As explained before, UVA initiates Type I or II reactions, with the latter being oxygen dependent, indicating its subsequent implication in indirect mechanisms, distinguished by the initiation by chromophores or photo-sensitizers, for Type I and II, respectively [100]. Type II reactions have even been separated into two categories, minor (superoxide radical anion-) and major (singlet oxygen-related) reactions, depending on the chemical properties of the facilitator [118]. In this review, Type II reactions will not be further distinguished in minor and major. 
As seen in Figure 3, the damage in this category of reactions, is a result of energy absorption of light by photosensitizers, and excitation to singlet state $\left({ }^{1}\right.$ sens $\left.{ }^{*}\right)$. Through intersystem crossing, relaxation and/or internal conversion the triplet state generation is induced $\left({ }^{3}\right.$ sens $\left.{ }^{*}\right)$, then energy transfer to molecular oxygen takes place plus the subsequent production of ROS. The main enabler of electron transfer is guanine, which demonstrated high reactivity with singlet oxygen $[110,119]$. The photosensitizing abilities of guanine must not be excluded either; the photo-oxidation of DNA appears most frequently as studied 8-oxo-7,8-dihydroguanine (8-oxoGua) [97]. In the same work, the evaluation of hydroxyl radical formation via photosensitization was also evaluated, which can induce a variety of DNA lesions.

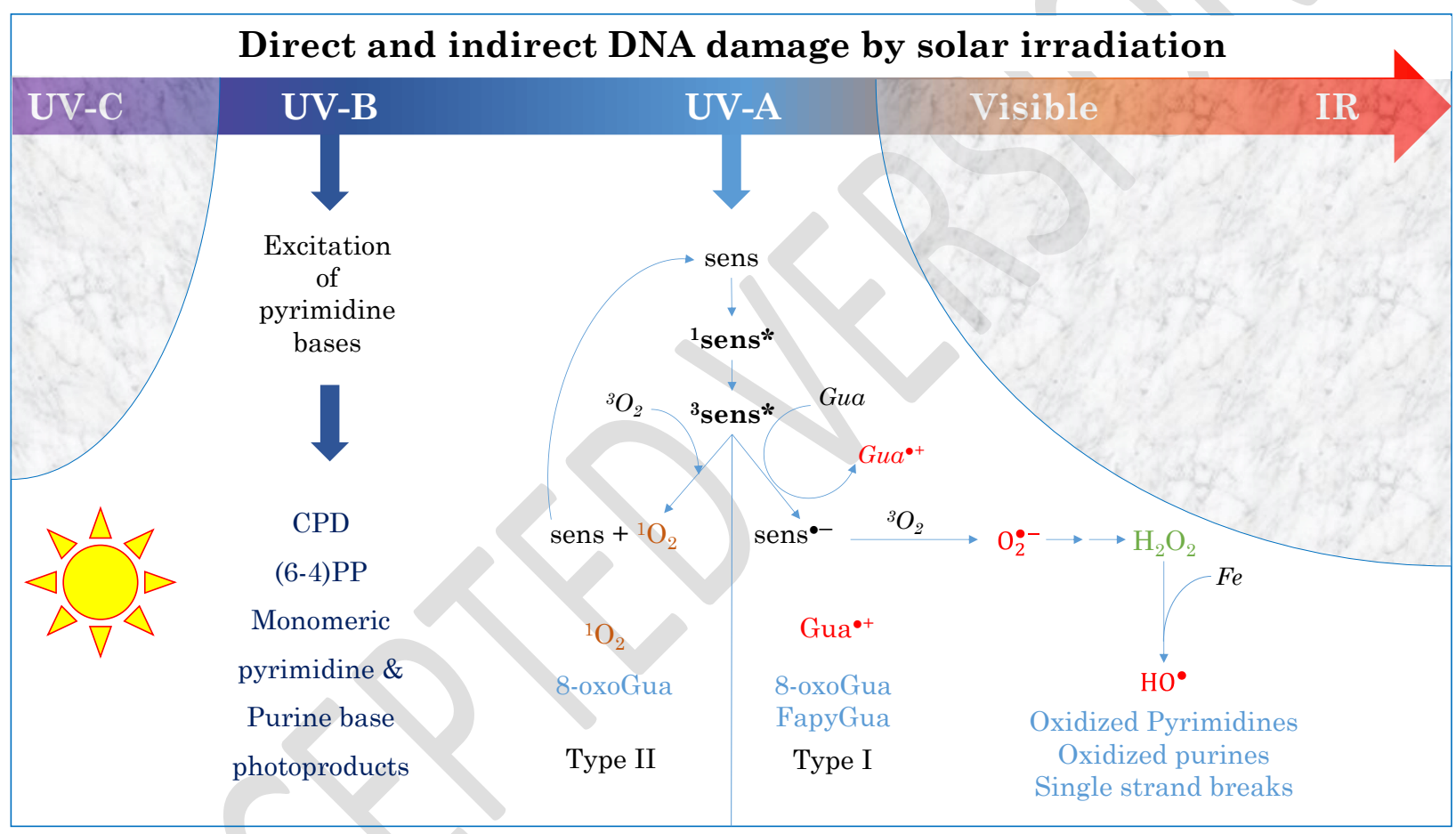

Figure 3 - Direct and indirect DNA damage mechanisms (adapted from Cadet et al. [120]). The different pathways initiated from UVB and the Type I and II induced by UVA are depicted, limited to the DNA damage as end-product.

These modes of action explain the comparative examination performed by Santos et al. [121], who compared the damage inflicted by either UVC, UVB or UVA light. It was found that the lightest damage (high survival rates and activity) was achieved under UVA light, but was induced by the highest ROS measured, as well as protein and lipid oxidation. This order was inversed for double strand breaks, as we move towards UVC light. Here, in order to further elucidate the inactivation mechanisms initiated 
by light, the different ROS produced and their relationship with the functional moieties of the cell, as well as the targets of damage via indirect pathways are further analyzed in the next subchapters.

\subsection{Reactive Oxygen Species (ROS) as a part of the cell life cycle}

\subsubsection{ROS as physiological intermediates}

ROS are a natural part of the respiratory cycle of bacteria [122], when growing in aerobic conditions. The prevailing ROS formed in a trivial way are the superoxide anion $\left(\mathrm{O}_{2}^{-}\right)$and hydrogen peroxide $\left(\mathrm{H}_{2} \mathrm{O}_{2}\right)$ [123]. The process can be simplified as a spontaneous oxidation of redox enzymes, playing the role of reductants, by molecular oxygen. Since oxygen is uncharged, its presence inside the cell is unambiguous, and its internal concentration can be regarded equal to the external one [124]. The main reductants that have been identified so far are flavoenzymes [125], which facilitate transfer of electrons onto secondary compounds. Another path includes oxygen collision with a reduced flavoenzyme, resulting in electron transfer from FADH2 [123]. With the abundance of (both oxygen and) flavins, these ROS are produced in a relatively steady quantity [126]. It must be noted here that the superoxide radical anion $\left(\mathrm{O}_{2}^{\bullet-}\right)$ /hydroperoxyl radical $\left(\mathrm{HO}_{2}^{\bullet-}\right)$ are the initial products of electron transfer, but at near-neutral $\mathrm{pH}$, the non-radical form is prevailing [127]. In principal, since $O_{2}^{\bullet-}$ is the actual product of the electron acceptance by molecular oxygen, its symmetry (delocalization of electrons in the molecule) dictates little radical character; this explains the often common representation by $O_{2}^{-}$.

In in vitro tests, it has been found that $\mathrm{O}_{2}^{-}$and $\mathrm{H}_{2} \mathrm{O}_{2}$ also form during electron transport between reductant substances and oxygen [128-131]; therefore it can be concluded that the possible reactions involve both one- and two-electron transfer [131, 132]. The transfer is always completed in single steps, first by reaction of flavins with oxygen and formation of $O_{2}^{-}$and flavosemiquinone [123]. This product can either further react with oxygen (further forming $\mathrm{O}_{2}^{-}$) or more commonly, the former $\mathrm{O}_{2}^{-}$or the flavosemiquinone undergo transformation, finally forming $\mathrm{H}_{2} \mathrm{O}_{2}$, rather than $\mathrm{O}_{2}^{-}$[123].

\subsubsection{ROS imbalance in cells}

Normally, bacterial contain regulators of ROS to counter potential imbalances generated within the cells or withstand the ROS production by enzyme auto-oxidation [126]. The most known defense lines 


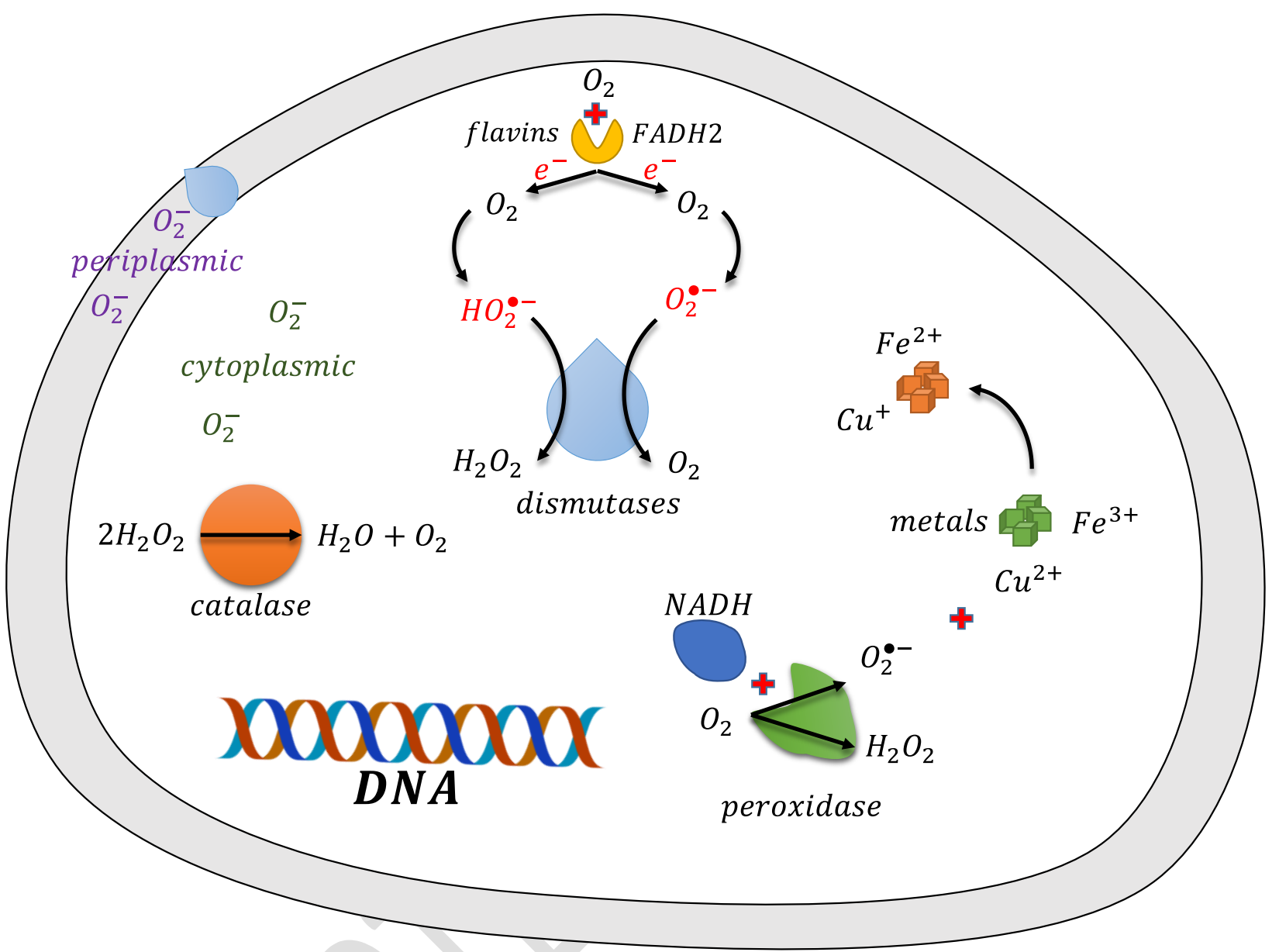

Figure 4 - Internal ROS cycle, before light addition. The opportunistic creation of ROS is depicted here, with the pair of superoxide radical anion $\left(\mathrm{O}_{2}^{--}\right)$/hydroperoxyl radical $\left(\mathrm{HO}_{2}^{\bullet^{-}}\right)$being the most reactive species. Their scavenging efficiency determines the auto-damage levels, via direct damage (oxidation) or indirect creation of more reactive $\mathrm{ROS}$ in reduced-metal catalyzed reactions with $\mathrm{H}_{2} \mathrm{O}_{2}$.

Catalase is the enzyme mainly responsible for the decomposition of $\mathrm{H}_{2} \mathrm{O}_{2}$ in water and oxygen [135]. Also, Ahp Alkyl hydroperoxide reductase scavenges the activity of the normally produced $\mathrm{H}_{2} \mathrm{O}_{2}$ in $E$. coli. Although $\mathrm{H}_{2} \mathrm{O}_{2}$ itself is not an immediate threat to DNA (may only cause oxidation of adenine [136], it engulfs the danger of hydroxyl radical production [137]. However, $\mathrm{H}_{2} \mathrm{O}_{2}$ accumulation can be detrimental to cell survival, as it will be analyzed later. Superoxide dismutases (Mn, Fe- or CuZn-SOD) are the enzymes burdened with the dismutation of $O_{2}^{-}$to $\mathrm{O}_{2}$ and $\mathrm{H}_{2} \mathrm{O}_{2}$ [138]. Their presence is located in both cytoplasm and periplasm of the cell [126]. Function-wise, they are similar, but the diffusion limitation of $O_{2}^{-}$at neutral $\mathrm{pH}[139,140]$ imposes their presence in both places. The superoxide radical 
itself is relatively unreactive towards DNA but is attributed to participate in a variety of biochemical reactions away from it. Among others, it can cause peroxynitrite formation [141, 142], thymine reduction and oxidation of transition metals. Also, superoxide can react with $\mathrm{H}_{2} \mathrm{O}_{2}$ and result in the production of hydroxyl radicals [134]. Finally, peroxidases mainly dehydrogenate $\left(\right.$ by $\left.\mathrm{H}_{2} \mathrm{O}_{2}\right)$ phenolic and endiolic compounds, but are also responsible for the reduction of $\mathrm{O}_{2}$ to $\mathrm{O}_{2}^{\bullet-}$ and $\mathrm{H}_{2} \mathrm{O}_{2}$, using dihydroxyfumarate or NADH [143]. It has been mentioned however, that some other microbes use reductases and peroxidases, rather than dismutase and catalase, respectively, for effective internal ROS scavenging [123].

When solar light is provided to the bacterial cells, the chain reaction of events is comprised from a complex mechanism, initiated by two simultaneous fronts: action of light and action of ROS. Assuming that a cell is preserving its normal ROS cycle, light addition creates a chain of oxidative events. UVB was mentioned to affect catalase functions, and therefore enhance $\mathrm{H}_{2} \mathrm{O}_{2}$ accumulation, and also, induce excess $O_{2}^{-}$production in $E$. coli cells in vivo [144, 145]. Also, singlet oxygen $\left({ }^{1} \mathrm{O}_{2}\right)$, a key factor in cytotoxicity and gene expression [146-148] can be generated by UVA irradiation, through excitation of chromophoric substances, such as porfyrins [148].

As it seems, there is an over-accumulation of ROS inside the cell, which is only made worse by the inactivation of the key enzymes by the action of light; CAT and SOD reduce significantly their activity when exposed to UVB or UVA light $[121,123,126]$. It has been long suggested that near-UV induces mutations in bacteria (in macroscopic level) and the explanation has been attributed to the excess $\mathrm{H}_{2} \mathrm{O}_{2}$ accumulated into the cell and the subsequent reactions involved with it [91]. UVA has also been known to affect the respiratory chain of $E$. coli, with some of the mechanisms suggested by Bosshard et al. [122] being verified in this cycle of events. The possibility of a malfunctioning electron transport chain would provide electrons, with many reductants now available to accept them and convert themselves to reactive intermediates. Also, the oxidizing agents' accumulation will lead to ROS production by internal metal- and $\mathrm{NAD}(\mathrm{P}) \mathrm{H}$-driven reactions [149]; the reductants will act towards the regeneration of the catalysts of these reactions. Therefore, in this point, it is important to analyze the release of metals and their result.

\subsection{The significance of the internal Fenton process: iron release and facilitation}




\subsubsection{Physiological state of iron into the cell}

422 Iron homeostasis in bacterial cells is controlled and kept in physiological levels by the Fur protein. It is the most common iron regulator (among others) in bacteria [150], controlling the genes implicated in iron acquisition, but also de-repression of the genes during iron deprivation [151]; the genes which encode proteins concerning direct $\mathrm{Fe}^{2+}$ acquisition or the transfer of $\mathrm{Fe}^{3+}$ by siderophoric action are negatively regulated by Fur $[152,153]$, acting as a repressor of transcriptional activity [151]. $\mathrm{Fe}^{2+}$ is soluble enough to feed the growth needs of bacteria, but the problems are found with $\mathrm{Fe}^{3+}$. Usually, it is solubilized by siderophores produced by bacteria, chelating and efficiently delivering $\mathrm{Fe}^{3+}$. Especially in near-neutral values, the aqua-complexes of $\mathrm{Fe}^{3+}$ are insoluble in water [154], and the siderophoric action facilitates their use. In total, bacteria utilize many transport systems to satisfy their needs; for instance, E. coli K-12 use 7 transport systems. Interestingly, although the siderophore movement through the outer membrane is excluded due to size of the protein, the gram-negative bacteria tend to use the outer surface receptor proteins as transport ones [155].

Internally, iron in E.coli is deposited in compounds such as bacterioferritin and ferritin [155-158]. Ferritin is essentially an iron storage unit, with a molecular weight of $444.000 \mathrm{kDa}$ and $4500 \mathrm{~mol}$ $\mathrm{Fe} / \mathrm{mol}$ protein. Its structure is complex, consisting of 24 sub-units, a protein surface cover (apoferritin) and 6 places for interior communication. Its function consists in storage of "free", nonprotein-bound iron into the cell, oxidizing the $\mathrm{Fe}^{2+}$ with the aid of proteins [159]. On a reverse function, it can release $\mathrm{Fe}^{2+}$ from the stored $\mathrm{Fe}^{3+}$ by the use of reducing biological compounds. This function is crucial for the cell, but it can provide a potential target for the oxidants accumulated into the cell during oxidative stress. Also, other iron containing units are the $\mathrm{Fe} / \mathrm{S}$ clusters. Dehydratases contain [4Fe-4S] clusters which include readily soluble iron atoms, prone to oxidation as well [157]. Finally, iron can also bind to the surface of the DNA structure and specifically, it is chelated to the phosphodiester backbone [17].

\subsubsection{Light-induced changes in iron homeostasis}

446 During light exposure, iron is playing a key role in the subsequent oxidative stress. There are two 447 possible ways of iron release into the cell: the ROS-mediated and the direct damage to the iron containing compounds.

449 The ROS production, as described in the previous chapter can play the role of the intermediate, which

450 "unlock" the structures and release iron into the cell. More specifically, the superoxide anion can extract iron from the iron-storage proteins [160-163], through oxidation of dehydratases, for instance. As described before, the critical iron atom is bound and the cluster is left in an unstable state [126]; 
the $[4 \mathrm{Fe}-4 \mathrm{~S}]^{2+}$ form is univalently oxidizing the cluster to $[4 \mathrm{Fe}-4 \mathrm{~S}]^{3+}$, resulting into released ferrous iron and $[3 \mathrm{Fe}-4 \mathrm{~S}]^{+}$cluster $[163,164]$. Hydrogen peroxide causes similar damage [165] by a two-step process, releasing ferric iron and the same $[3 \mathrm{Fe}-4 \mathrm{~S}]^{+}$cluster [164]. The simultaneous production of "free" iron, $\mathrm{H}_{2} \mathrm{O}_{2}$ and superoxide radical anion which can reduce $\mathrm{Fe}^{3+}$ to $\mathrm{Fe}^{2+}$ [17], can effectively facilitate an internal Fenton reaction.

As far as the light itself is concerned, the previous actions simply aggravate. Near UV is known to degrade membrane structures inside the cell [166]. More specifically, Fe/S clusters absorb in the UVA region [112]. UVA has been found to degrade ferritin and other ferritin-like substances, leading to immediate release of iron into the cytoplasm $[148,167,168]$ via destruction of its ligand [112]. Most importantly, in presence of these chelating ligands and ROS, the Fenton reaction is already taking place, producing $\mathrm{HO}^{\bullet}$. Taking into account the incident light in these wavelengths, the Fenton reaction will find its catalyst regenerated back to $\mathrm{Fe}^{2+}$ with the simultaneous production of another hydroxyl radical.

\subsection{Internal targets of the oxidative damage}

Light action against the cell presents a uniformity in its application, if saturation conditions are applied. Although some compounds demonstrate a photo-absorbing activity, it is rather unlikely that shading occurs significantly, if no physical barriers exist. However, this statement does not stand equally true for the ROS damage during oxidative stress conditions, since ROS are short living, and in their majority, diffusion limited. Therefore, except for the long-living $\mathrm{H}_{2} \mathrm{O}_{2}$ and $O_{2}^{-}$the rest cause "local" damage. The effects can be separated according to the mediator (ROS) or the target; here, the latter is going to be presented, separating the damage on the DNA, and the rest of the involved compounds (proteins, enzymes, lipids etc).

\subsubsection{Oxidative-driven DNA damage}

DNA was long identified as a weak link in the chain of resistance to ROS damage by light-initiated internal Fenton reactions, for two main reasons: it was mentioned that it can effectively bind loose iron $[17,75]$ catalyzing the Fenton reaction and suffering oxidative damage at the site of reaction. Then, the possibility of withholding such damage is considerably more crucial to survival than in other compounds of the cell [17]. Diffusion-limited oxidative damage by $\mathrm{HO}^{\bullet}$ can induce different effects, 
484

consequence of the reaction with $\mathrm{HO}^{\bullet}$ [172], since the reaction with deoxyribose leads to base loss, as well as with thymine $[17,173]$.

The hydroxyl radicals are non-selective in their mode of action. Their reaction with purine bases leads to C8-hydroxylated radical, which increases 8-oxoGua, FapyGua, 8-oxoAde and FapyAde [167]. Also, their reaction at the $\mathrm{C5}-\mathrm{C} 6$ double bond ends up in the thymine and cytosine and uracil methyl oxidation by-products, 5,6-dihydroxy-5,6-dihydrothymine, 5,6-dihydroxy-5,6-dihydrocytosine and Hydroxymethyluracil and 5-formyluracil, respectively [174]. Finally, hydrogen abstraction from 2deoxyribose moieties demonstrates strand breaks end-products [174]. Less reactive ROS, such as singlet oxygen, react with nucleotide bases at different k constants reported [175]. It is noteworthy that the most prone base is again guanine, and the final damage by-product being the 8-oxodGua. Furthermore, ROS can attack the sugars of the DNA, with a variety of end-products actually formed [176]. The final result is lesions which are either misread by repair enzymes or blocking this process; the latter type leads to growth impairment and cell death [177].

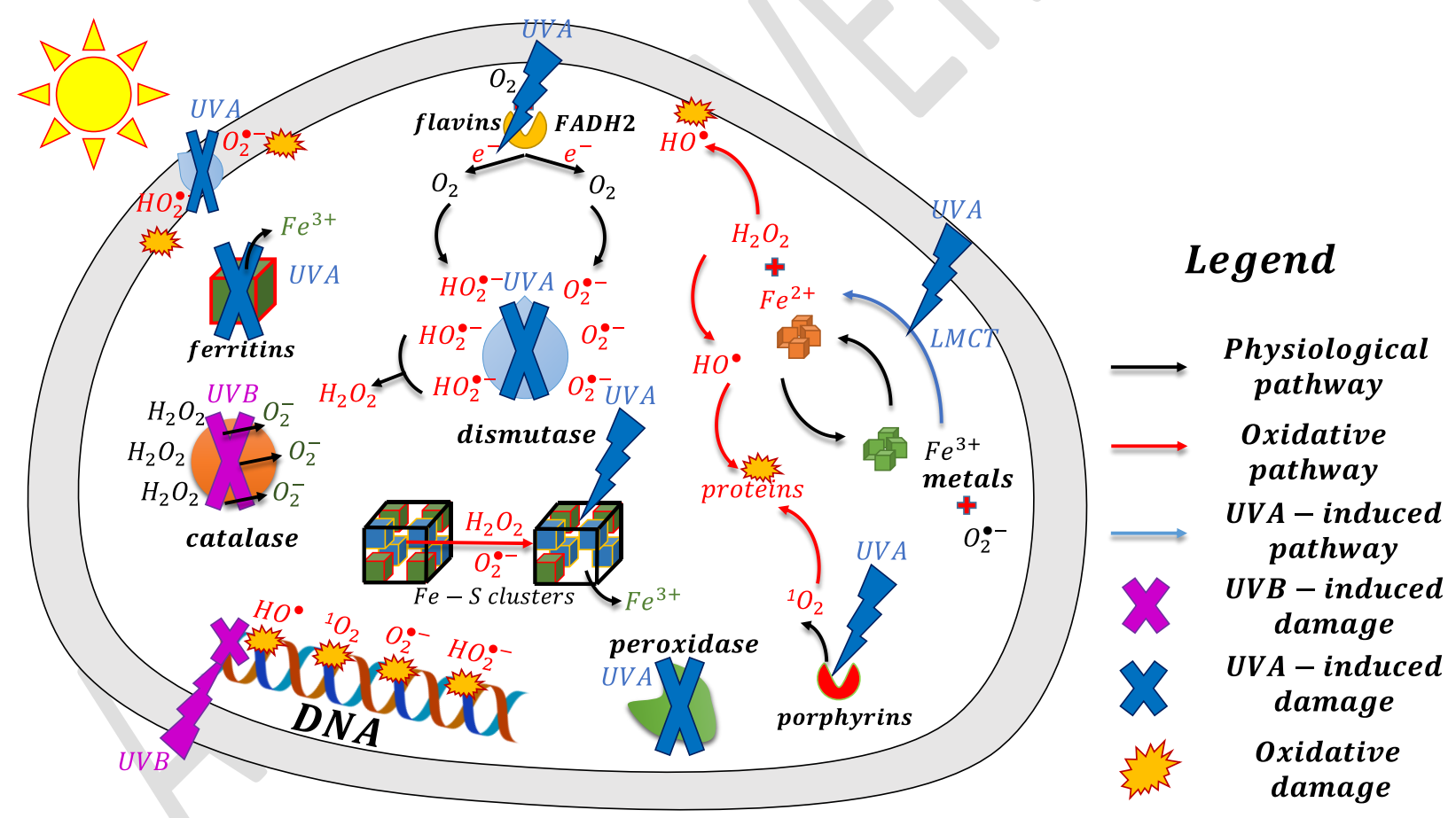

Figure 5 - Light induced changes in cell homeostasis. a) UVB-induced damage to DNA and CAT functions, b) UVA affects the functions of enzymes and proteins related with the ROS production (flavins, FADH2, CAT, SOD, peroxidases, porphyrins), leading to accumulation of ROS, c) release of iron and reduction by light, d) LMCTdriven reduction of iron and internal photo-Fenton initiation. 
504

One of the first and major targets of oxidative stress during light exposure of bacteria are proteins

505

506

507

508

509

510

511

512

513

514

515

516

517

518

519

520

521

522

523

524

525

526

527

528

529

530

531

533

534

[177]. Although it was long believed that DNA damage and lipid peroxidation are the most prone to oxidative stress, proteins have arisen as important points of interest [178]. Both $\mathrm{HO}^{\bullet}$ and ${ }^{1} \Delta g \mathrm{O}_{2}$ have been reported to inflict severe and diverse problems onto the normal protein functions. Firstly, there are functional modifications in proteins, onto amino acids and protein side chains [134]. Proteins suffer from structural modifications and aggregation [179] carbonylation etc [180]. Modifications in sulfur groups (oxidation of sulfhydryl groups or reduction of disulfides), as well as oxidation of amino acids due to hydroxyl radicals, protein agglutination and cross-linking, aldehyde reactions and fragmentation of peptides have also been reported [181-186]. Especially, proteins involved in the respiration process are in danger, such as F1FO ATPase and respiratory enzymes [180]. Modification of 3-D structure $[187,188]$ changes in metal binding properties, susceptibility towards proteolysis and unfolding [75] should also not be excluded. Protein modifications' effect can vary from mild to severe, inducing irreversible damage to the cell [180], including cellular metabolism failures [134], membrane modifications (loss of function) [189], blocking of DNA replication, mutations [181] etc.

Singlet oxygen is not as reactive as the hydroxyl radical, but has a much longer half-life time, however possesses an ability to affect protein functions has stated it as a potentially dangerous agent, as it can react with amino acids directly. It reacts with tryptophan, tyrosine, histidine, methionine, cysteine and cysteine residues [75]. It is also responsible for inactivating enzymes, forming protein peroxides or side-chain by-products, fragmenting the backbone, as well as cross linking and aggregation [90]. Many functions are common with the effect of the hydroxyl radical, proving its significance. Also, if not destroyed, there can be an effect of the properties of the protein, such as its turnover efficiency [90]. Proteins are also in danger from the indirect pathway of the hydrated electrons, which add to molecular oxygen, result in $\mathrm{O}_{2}^{\bullet-}$ and can subsequently damage proteins [75].

Moving to even more inert ROS, $\mathrm{O}_{2}^{-}$and $\mathrm{H}_{2} \mathrm{O}_{2}$ can affect other groups, such as $\mathrm{Fe} / \mathrm{S}$ dehydratases or mononuclear Fe-enzymes [177]. Superoxide is less harmful although more reactive than $\mathrm{H}_{2} \mathrm{O}_{2}$ [123] and acts mostly in blocking the [4Fe-4S] clusters as described before; the inactivation of this enzyme causes pathway failure. $\mathrm{H}_{2} \mathrm{O}_{2}$ on the other hand, can oxidize sulfur atoms (oxidation of cystenyl residues, or oxidation towards sulfinic moieties) [123], or (through $\mathrm{HO}^{\bullet}$ ) carbonylate proteins, and oxidize Fe/S clusters [123].

Finally, although some of the targets presented seem like end-products, there are significant sideproducts possibly forming, inducing secondary damage [75]. For instance, the peroxides formed on 
535 proteins and peptides can cause oxidation of residues on other proteins or deplete antioxidants [190], 536 or even increase the possibility of DNA-base oxidation [191], with the consequences already analyzed 537 before (i.e. strand breaks and DNA-protein adducts).

538 The second large group of damage is lipids and fatty acids. A proposed chain reaction of autocatalytic 539 lipid peroxidation has been proposed [172], where oxidation by $\mathrm{HO}^{\bullet}$ leaves a lipid radical anion readily 540 reacting with molecular oxygen to form lipid peroxyl radicals. This radical can potentially play the role 541 of $\mathrm{HO}^{\bullet}$ in the next cycle, and form this auto-oxidation process. Metals and $\mathrm{H}_{2} \mathrm{O}_{2}$ can generate the 542 necessary $\mathrm{HO}^{\bullet}$, singlet oxygen [148] or the secondary damage by protein photoproducts could initiate 543 the peroxidation process. Some authors have suggested the dangers of lipid peroxidation [122, 192] 544 but in order to facilitate this reaction, the bacteria must contain the poly-unsaturated lipids; it is 545 suggested that most membranes lack these compounds [122]. 


\section{Chapter III: Enhancements}

548 1. Hydrogen peroxide $\left(\mathrm{H}_{2} \mathrm{O}_{2}\right)$.

550 In the previous chapters, we have revised the actions that take place during sole irradiation of bacteria 551 by light, including UVB, UVA and visible light. The various mechanisms that have been described, lead 552 to the assertion that the main mechanisms of cellular inactivation by light are two: direct light action 553 (mutations, strand breaks etc.) and indirect light-initiated pathways (ROS formation, iron release and 554 the subsequent internal Fenton and photo-Fenton reaction). During the ROS formation, superoxide 555 and $\mathrm{H}_{2} \mathrm{O}_{2}$ have been found critical in the facilitation of the internal photo-Fenton reaction, in both 556 direct damage to bio-molecules and indirect aggravation of ROS production. In this chapter, we assess 557 the enhancement of photo-inactivation of bacteria, by the simple addition of $\mathrm{H}_{2} \mathrm{O}_{2}$, and present the 558 mechanisms that take part internally and externally, in absence or presence of light.

\section{1. $\mathrm{H}_{2} \mathrm{O}_{2}$ actions, in absence of light}

Hydrogen peroxide $\left(\mathrm{H}_{2} \mathrm{O}_{2}\right)$ is a relatively strong oxidant, with potential $1.8 \mathrm{~V}$ at $\mathrm{pH}=0$ and $0.87 \mathrm{~V}$ at $\mathrm{pH}$ $=14$ [193]. In natural waters, its formation is connected with photochemical mechanisms, explained in next chapters of the review, or the release of metals and sulfur from anoxic regions [194]; when near-neutral conditions are encountered, the expected potential is around $1.4 \mathrm{~V}$. Its use in biologicalrelated activities was connected with disinfection and biofilm growth control [193].

566 As analyzed in the previous chapter, intracellular $\mathrm{H}_{2} \mathrm{O}_{2}$ is a normal by-product of the respiration 567 process, through the auto-oxidation of respiratory dehydrogenases of bacteria [123], which in turn 568 can regulate and maintain these ROS concentrations to nanomolar levels, by catalases and 569 peroxidases [195]. However, the $\mathrm{H}_{2} \mathrm{O}_{2}$ is present in the surroundings of the microorganism, since it is 570 an uncharged molecule, it is known to diffuse through membranes, therefore facilitating its transport 571 into the cell [195]. Therefore, a steady state concentration is preserved, as a balance of its intracellular 572 generation, the potential diffusion from outer sources and the scavenging efficiency from the enzymes 573 [196]. Different physiological states can imply varying steady state concentrations [197]. The 574 imbalance created into the cell can be either scavenged or inactivate enzymes; reports mention $20 \%$ 
death. In order to separate the different pathways with which $\mathrm{H}_{2} \mathrm{O}_{2}$ can lead to cell inactivation, the lieu and the mode will be assessed.

Beginning with the external actions, as $\mathrm{H}_{2} \mathrm{O}_{2}$ can be either naturally produced or voluntarily added, a wide range of concentrations can be encountered. Imlay and Linn [198] have experimented with mM concentrations of $\mathrm{H}_{2} \mathrm{O}_{2}$, and a correlation with $\mathrm{H}_{2} \mathrm{O}_{2}$ addition and cell inactivation was confirmed [17, 198]. Two main categories of concentrations can be suggested: low (1-3 mM) $\mathrm{H}_{2} \mathrm{O}_{2}$ and high concentrations $(>20 \mathrm{mM})$. The outcome of this investigation suggested internal and external damage, respectively, for the two categories, namely Mode I and Mode II [199]. Mode II involves external $\mathrm{H}_{2} \mathrm{O}_{2}$ reacting probably directly with the cellular membrane, thus increasing its permeability; this increase can permit the inflow of extra concentrations of $\mathrm{H}_{2} \mathrm{O}_{2}$, as well as the overall detrimental impact on the viability of the cell [200]. A proportionality has been reported up to $100 \mathrm{mM}$ [198].

However, the actions implicated in Mode I damage are far more intriguing. In summary, these actions are enhancing the internal Fenton reaction as it was presented in the previous chapter. More specifically, it was evidenced in [201] by the $\mu \mathrm{M}$ concentrations that disrupted catabolic and biosynthetic functions of the cell, by the destruction of Fe/S clusters $[157,164,202,203]$. The damaged cluster contributes to loose iron release and the excess of $\mathrm{H}_{2} \mathrm{O}_{2}$ will initiate Fenton reactions. However, $\mathrm{H}_{2} \mathrm{O}_{2}$ is not the only oxidant, but can act as a scavenger of electrons. More specifically, through one-electron transfer, hydroxyl radicals $\left(\mathrm{HO}^{\bullet}\right)$ can be generated. Also, via either direct or indirect pathways, Mode I killing will take place [198]. Also, hydrogen peroxide can scavenge $\mathrm{HO}^{\bullet}$, leading to the creation to the less reactive superoxide anion [198], which as we have analyzed before has a lower oxidative potential, but is biologically significant, because of its strong affinity with bacterial components [159]; plus, it is far more long-living than $\mathrm{HO}^{\bullet}$. Therefore, there are interesting Fenton-related implications involved, if a considerable amount of $\mathrm{H}_{2} \mathrm{O}_{2}$ is added to the bulk and saturation conditions are to be taken into account.

A very interesting concept has also been discussed in literature, concerning the nature and significance of the Fenton reaction itself [201, 204, 205], and more specifically, the effect of the reaction kinetics. The $\mathrm{k}$ constant for the oxidation of $\mathrm{Fe}^{2+}$ at $\mathrm{pH}$ values around 3 is $76 \mathrm{M}^{-1} / \mathrm{s}^{-1}$ [11]. This value was considered too low to be important, especially for micro-molar (or lower) concentrations. Also, the reduction of $\mathrm{Fe}^{3+}$ back to $\mathrm{Fe}^{2+}$ is around 100 times slower. However, at near-neutral $\mathrm{pH}$, it was found that [201] $\mathrm{Fe}^{3+}$ in aqua- hydroxy-complexes is often found with lower reduction potentials, due to its coordination by the hydroxide anion $\left(\mathrm{OH}^{-}\right)$. The result is a reaction constant $\mathrm{k}$ around $20.000-30.000$ $\mathrm{M}^{-1} \mathrm{~s}^{-1}$, which withholds more implications; this high reactivity indicates the need for the bacteria to 
scavenge the intracellular nano-quantities of $\mathrm{H}_{2} \mathrm{O}_{2}$, because of the apparent toxic activity implicated [164].

\subsection{Light-assisted $\mathrm{H}_{2} \mathrm{O}_{2}$ mode of action}

In general, $\mathrm{H}_{2} \mathrm{O}_{2}$ addition is performed in $\mu \mathrm{M}$ to $\mathrm{mM}$, which place the action into the Mode I killing, but on the other hand, the concentrations used might be considered as low; Rincon and Pulgarin, Spuhler et al., or Garcia-Fernandez et al. [31, 40, 206] below $15 \mathrm{mg} / \mathrm{L}(0.44 \mathrm{mM})$ did not find any inactivation, Sciacca et al. with $10 \mathrm{mg} / \mathrm{L}(0.29 \mathrm{mM})$ found 2-log reduction and Ndounla et al. negligible inactivation in the dark with $8.5 \mathrm{mg} / \mathrm{L}(0.25 \mathrm{mM}) \mathrm{H}_{2} \mathrm{O}_{2}[30,45]$. Nevertheless, the diffusion into the cell, and the light addition into the sample can offer conditions for effective internal photo-Fenton reaction and fast regeneration of ferric iron back to ferrous.

The first instance on synergistic inactivation by near-UV light and $\mathrm{H}_{2} \mathrm{O}_{2}$ was demonstrated by Anathaswamy and Eisenstark [207] for phages and Hartman and Eisenstark some years later [208] for E. coli $\mathrm{K}-12$. The following years many works have been developed to assess the $\mathrm{H}_{2} \mathrm{O}_{2}$-enhanced photokilling modes and parameters that are involved [30,31, 40, 209-214]. The majority of the works agree that the involved mechanism is in fact a light-enhanced internal photo-Fenton reaction. The prevailing mechanism is as follows.

1) The direct damage of the light affects the DNA and the enzymes responsible for its reparation (direct action).

2) Light is disrupting the normal ROS-scavenging enzymes into the cells such as catalase, superoxide dismutase, peroxidases etc. (indirect action)

3) $\mathrm{H}_{2} \mathrm{O}_{2}$ penetrates the cell, causing imbalance of ROS into the cells.

4) ROS and light release iron into the cytoplasm, with reacts with $\mathrm{H}_{2} \mathrm{O}_{2}$ to create $\mathrm{HO}^{\bullet}$. Other ROS are involved into the reduction of iron, direct attack to susceptible moieties (oxidative stress).

5) Added $\mathrm{H}_{2} \mathrm{O}_{2}$ affects bacterial membrane (outer damage), initiating its auto-oxidation.

6) Light reduces ferric iron to ferrous directly, through ligand-to-metal charge transfer (LMCT) or indirectly, through the reactive intermediates available by the light-induced malfunctioning into the cell, initiating a photo-catalytic cycle.

Concerning the suggested mechanism, there are some indications that confirm the majority of these actions or limit to a certain extent. For instance, it is suggested that in aerobic, near-neutral conditions, the LMCT could not proceed for hours [215], so the sources of iron need to be replenished. In the majority of the cases, this time frame will not be required for bacterial inactivation; nevertheless, in 
640 these conditions $\mathrm{Fe}^{3+}$ is expected to precipitate and not participate further into the inactivation 641 mechanism. Also, there was a linear increase of the inactivation kinetics by increasing the added $\mathrm{H}_{2} \mathrm{O}_{2}$ 642 from 0 to $500 \mathrm{mM}$ or 0-10 mg/L for Fisher et al. or Garcia-Fernandez et al. [40, 209], respectively. It is 643 suggested that the internal Fenton is taking place and also, $\mathrm{Fe}^{2+}$ is not the limiting reagent in the 644 reaction. Therefore, there is a constant iron release and reduction, in an efficient catalytic cycle.

645 
647 So far, the light-induced oxidative stress and the voluntary addition of $\mathrm{H}_{2} \mathrm{O}_{2}$ have been assessed. In 648 these actions, internal damage directly or indirectly by light has been inflicted, and an internal photo649 Fenton has been established. $\mathrm{H}_{2} \mathrm{O}_{2}$ addition has proven to enhance the internal photo-Fenton, 650 therefore in this part, we present the events that take place if the matrix contains iron or if iron is added at will. The various events, such as the homogeneous Fenton, the heterogeneous Fenton and the semiconductor mode of action by the iron oxides will be further analyzed. But first, the role of iron, the various forms and formations in natural waters are presented.

654

\subsection{Iron as the Fenton reaction catalyst.}

More than 100 years after the discovery of the Fenton reaction, iron still remains the most commonly employed metal catalyst for the fulfillment of $\mathrm{HO}^{\bullet}$ generation from this method [216]. The use of iron employs a series of characteristics which are rarely encountered simultaneously in other metals. For instance, its versatility in gaining various oxidation states $(-2$ to +6$)$, which derives from its position in the periodic table of elements [217], the characteristic abundance as far as its mass availability is concerned, the low toxicity implicated in its utilization and easy integration, state iron as the principal facilitator of the Fenton reaction [216]. Its coexistence with $\mathrm{H}_{2} \mathrm{O}_{2}$ initiates the Fenton reaction. The different types of Fenton reaction are summarized in Table 2 [218].

Table 2 - The different types of the Fenton reaction (adapted from [218].

\begin{tabular}{c|cccc}
\multicolumn{1}{c}{ Process } & Reagents & Light & $\boldsymbol{p H}$ & Iron Loss \\
\hline $\begin{array}{c}\text { Classic Fenton } \\
\text { Fenton-like }\end{array}$ & $\mathrm{H}_{2} \mathrm{O}_{2}, \mathrm{Fe}^{2+}$ & No & 2 to 4 & Yes \\
$\begin{array}{c}\text { Photo-Fenton } \\
\text { Heterogeneous } \\
\text { Fenton }\end{array}$ & $\mathrm{H}_{2} \mathrm{O}_{2}, \mathrm{Fe}^{3+}$ & No & 2 to 4 & Yes \\
$\begin{array}{c}\text { Heterogeneous } \\
\text { photo-Fenton }\end{array}$ & $\mathrm{H}_{2} \mathrm{O}_{2}$, iron complexes, free iron ions & Yes & Acidic to neutral & Yes \\
$\mathrm{H}_{2} \mathrm{O}_{2}$, solid iron oxide & No & wide range & No \\
& $\mathrm{H}_{2} \mathrm{O}_{2}$, solid iron oxide & Yes & wide range & No
\end{tabular}

The most common forms of iron salts used for the Fenton reaction are $\mathrm{Fe}^{2+}$ and $\mathrm{Fe}^{3+}$. These two salts are used mostly due to the low mass transfer limitations among them and the oxidants [219]. One of the main differences among the two forms are the characteristic insolubility of $\mathrm{Fe}^{3+}$ in slightly acidic and near-neutral $\mathrm{pH}$ values, making it difficult to operate outside the strict acidic region [217]. $\mathrm{pH}$ 
dependence is a matter strongly affecting iron speciation, and will be further analyzed later. Also, although $\mathrm{Fe}^{2+}$ is borderline categorized as a hard acid, $\mathrm{Fe}^{3+}$ shows a preference in hard oxygen ligands; $\mathrm{Fe}^{2+}$ favors sulfur and nitrogen ligands [217]. Finally, among the Fenton reactions initiated by $\mathrm{Fe}^{2+}$ or $\mathrm{Fe}^{3+}$, a small differentiation has been made, and if the starting form of iron is $\mathrm{Fe}^{3+}$, the reaction is named Fenton like. A summary of the Fenton and Fenton-like reactions is proposed in Table 3. from [220]).

Reaction No.

\section{Reaction}

$$
\begin{aligned}
& \mathrm{Fe}^{3+}+\mathrm{H}_{2} \mathrm{O} \leftrightarrow \mathrm{Fe}(\mathrm{OH})^{2+}+H^{+} \quad\left(k_{1}=2.9 \times 10^{-3} \mathrm{M}\right) \\
& \mathrm{Fe}^{3+}+2 \mathrm{H}_{2} \mathrm{O} \leftrightarrow \mathrm{Fe}(\mathrm{OH})_{2}^{+}+2 \mathrm{H}^{+} \quad\left(k_{2}=7.62 \times 10^{-7} \mathrm{M}^{2}\right) \\
& 2 \mathrm{Fe}^{3+}+2 \mathrm{H}_{2} \mathrm{O} \leftrightarrow \mathrm{Fe}_{2}(\mathrm{OH})_{2}^{4+}+2 \mathrm{H}^{+} \quad\left(k_{2.2}=0.8 \times 10^{-3} \mathrm{M}\right) \\
& \mathrm{Fe}^{3+}+\mathrm{H}_{2} \mathrm{O}_{2} \leftrightarrow \mathrm{Fe}^{3+}\left(\mathrm{HO}_{2}\right)^{2+}+H^{+} \quad\left(k I_{1}=3.1 \times 10^{-3}\right) \\
& \mathrm{Fe}(\mathrm{OH})^{2+}+\mathrm{H}_{2} \mathrm{O}_{2} \leftrightarrow \mathrm{Fe}^{3+}(\mathrm{OH})\left(\mathrm{HO}_{2}\right)^{+}+H^{+} \quad\left(k I_{2}=2 \times 10^{-4}\right) \\
& \mathrm{Fe}^{3+}\left(\mathrm{HO}_{2}\right)^{2+} \rightarrow \mathrm{Fe}^{2+}+\mathrm{HO}_{2}^{\bullet} \quad\left(k_{6}=x 10^{-3} s^{-1}\right) \\
& \mathrm{Fe}^{3+}(\mathrm{OH})\left(\mathrm{HO}_{2}\right)^{+} \rightarrow \mathrm{Fe}^{2+}+\mathrm{HO}_{2}^{\bullet}+\mathrm{OH}^{-} \quad\left(k_{6}=x 10^{-3} \mathrm{~s}^{-1}\right) \\
& \mathrm{Fe}^{2+}+\mathrm{H}_{2} \mathrm{O}_{2} \rightarrow \mathrm{Fe}^{3+}+\mathrm{HO}^{\bullet}+\mathrm{OH}^{-} \quad\left(k_{7}=63 \mathrm{M}^{-1} \mathrm{~S}^{-1}\right) \\
& \mathrm{Fe}^{2+}+\mathrm{HO}^{\bullet} \rightarrow \mathrm{Fe}^{3+}+\mathrm{OH}^{-} \quad\left(k_{8}=3.2 \times 10^{8} \mathrm{M}^{-1} \mathrm{~S}^{-1}\right) \\
& \mathrm{HO}^{\bullet}+\mathrm{H}_{2} \mathrm{O}_{2} \rightarrow \mathrm{HO}_{2}^{\bullet}+\mathrm{H}_{2} \mathrm{O} \quad\left(k_{9}=3.3 \times 10^{9} \mathrm{M}^{-1} \mathrm{~s}^{-1}\right) \\
& \mathrm{Fe}^{2+}+\mathrm{HO}_{2}^{\circ} \rightarrow \mathrm{Fe}^{3+}\left(\mathrm{HO}_{2}\right)^{2+} \quad\left(k_{10 a}=1.2 \times 10^{6} M^{-1} \mathrm{~s}^{-1}\right) \\
& \mathrm{Fe}^{2+}+\mathrm{O}_{2}^{\bullet-}+H^{+} \rightarrow \mathrm{Fe}^{3+}\left(\mathrm{HO}_{2}\right)^{2+} \quad\left(k_{10 b}=1 \times 10^{7} M^{-1} S^{-1}\right) \\
& \mathrm{Fe}^{3+}+\mathrm{HO}_{2}^{\bullet} \rightarrow \mathrm{Fe}^{2+}+\mathrm{O}_{2}+H^{+} \quad\left(k_{11 a}<2 \times 10^{3} M^{-1} S^{-1}\right) \\
& \mathrm{Fe}^{3+}+\mathrm{O}_{2}^{\bullet-} \rightarrow \mathrm{Fe}^{2+}+O_{2} \quad\left(k_{11 b}=5 \times 10^{7} M^{-1} S^{-1}\right) \\
& \mathrm{HO}_{2}^{\bullet} \rightarrow \mathrm{O}_{2}^{\bullet-}+\mathrm{H}^{+} \quad\left(k_{12 a}=1.58 \times 10^{5} \mathrm{M}^{-1} \mathrm{~S}^{-1}\right) \\
& \mathrm{O}_{2}^{\bullet-}+H^{+} \rightarrow \mathrm{HO}_{2}^{\bullet} \quad\left(k_{12 b}=1 \times 10^{10} \mathrm{M}^{-1} \mathrm{~s}^{-1}\right) \\
& \mathrm{HO}_{2}^{\bullet}+\mathrm{HO}_{2}^{\bullet} \rightarrow \mathrm{H}_{2} \mathrm{O}_{2}+\mathrm{O}_{2} \quad\left(k_{13 \mathrm{a}}=8.3 \times 10^{5} \mathrm{M}^{-1} \mathrm{~s}^{-1}\right) \\
& \mathrm{HO}_{2}^{\bullet}+\mathrm{O}_{2}^{\bullet-}+\mathrm{H}_{2} \mathrm{O} \rightarrow \mathrm{H}_{2} \mathrm{O}_{2}+\mathrm{O}_{2}+\mathrm{OH}^{-} \quad\left(k_{13 \mathrm{~b}}=9.7 \times 10^{7} \mathrm{M}^{-1} \mathrm{~S}^{-1}\right) \\
& \mathrm{HO}^{\bullet}+\mathrm{HO}_{2}^{\bullet} \rightarrow \mathrm{H}_{2} \mathrm{O}+\mathrm{O}_{2} \quad\left(k_{14 \mathrm{a}}=0.71 \times 10^{10} \mathrm{M}^{-1} \mathrm{~S}^{-1}\right) \\
& \mathrm{HO}^{\bullet}+\mathrm{O}_{2}^{\bullet-} \rightarrow \mathrm{O}_{2}+\mathrm{OH}^{-} \quad\left(k_{14 \mathrm{~b}}=1.01 \times 10^{10} \mathrm{M}^{-1} \mathrm{~s}^{-1}\right) \\
& \mathrm{HO}^{\bullet}+\mathrm{HO}^{\bullet} \rightarrow \mathrm{H}_{2} \mathrm{O}_{2} \quad\left(k_{15}=5.2 \times 10^{9} \mathrm{M}^{-1} \mathrm{~S}^{-1}\right)
\end{aligned}
$$


678 A summary of the main parameters which affect the Fenton reaction efficiency, measured by the 679 production of $\mathrm{HO}^{\bullet}$, through the oxidation of $\mathrm{Fe}^{2+}$ to $\mathrm{Fe}^{3+}$, are involved in the following equation [221]:

$$
\frac{d\left[\mathrm{Fe}^{2+}\right]}{d t}=k\left[\mathrm{OH}^{-}\right]^{2} P_{\mathrm{O}_{2}}\left[\mathrm{Fe}^{2+}\right]
$$

680

681

682

683

684

685

686

687

688

689

$$
\begin{aligned}
-\frac{d\left[\mathrm{Fe}^{2+}\right]}{d t}=( & k_{0}\left[\mathrm{Fe}^{2+}\right]+k_{1}\left[\mathrm{Fe}(\mathrm{OH})^{+}\right]+k_{2}\left[\mathrm{Fe}(\mathrm{OH})_{2(a q)}^{0}\right] \\
& \left.+k_{3}\left[\mathrm{Fe}(\mathrm{OH})_{3}^{-}\right]\right) \mathrm{DO}
\end{aligned}
$$

Where partial pressure replaced by dissolved oxygen, since this is participating in the oxidation reaction, and $\mathrm{k}_{1}, \mathrm{k}_{2}, \mathrm{k}_{3}$ are oxidation rate constants.

The main regions of interest, as far as Eq. 2 is concerned, are below 4, between 5 and 8 and above 8 . At $\mathrm{pH}<4, \mathrm{Fe}^{2+}$ is the main species. Between 5 and $8, \mathrm{Fe}(\mathrm{OH})_{2(a q)}^{0}$ concentration is $\mathrm{pH}$-dependent (increasing from 5 to 8 ) and above 8, it is the dominating form. The three species in Eq.III 2 have rate constants of $6 \cdot 10^{-5}, 1.7$, and $4.3 \cdot 10^{+5} \mathrm{~min}^{-1}$, which is a big difference and also indicates the main Fespecies in near-neutral $\mathrm{pH}$. Below a pH value of $10, \mathrm{Fe}(\mathrm{OH})_{3}^{-}$is not likely to affect the process, since its concentration is insignificant. Also, the necessary time to oxidize $\mathrm{Fe}^{2+}$ depending on the $\mathrm{pH}$ varies approximately from $50 \mathrm{~min}$ at $\mathrm{pH}=7$ to 175 at $\mathrm{pH}=6.3$ and theoretically infinite at $\mathrm{pH}=4$ [154]. 


$$
\mathrm{Fe}^{2+}+\mathrm{H}_{2} \mathrm{O}_{2} \rightarrow\left[\mathrm{Fe}^{3+}-\mathrm{OH}\right]+\mathrm{HO}^{\bullet}
$$

700

701

702

703

704 705 706

And at near-neutral pH, we get [227]:

$$
\begin{gathered}
2\left[\mathrm{Fe}(\mathrm{OH})\left(\mathrm{H}_{2} \mathrm{O}\right)_{5}\right]^{2+}+\mathrm{H}_{2} \mathrm{O} \leftrightarrow\left[\mathrm{Fe}(\mathrm{OH})_{2}\left(\mathrm{H}_{2} \mathrm{O}\right)_{8}\right]^{4+}+2 \mathrm{H}_{2} \mathrm{O} \\
{\left[\mathrm{Fe}(\mathrm{OH})_{2}\left(\mathrm{H}_{2} \mathrm{O}\right)_{8}\right]^{4+}+\mathrm{H}_{2} \mathrm{O} \leftrightarrow\left[\mathrm{Fe}_{2}(\mathrm{OH})_{3}\left(\mathrm{H}_{2} \mathrm{O}\right)_{7}\right]^{3+}+\mathrm{H}_{3} \mathrm{O}^{+}} \\
{\left[\mathrm{Fe}_{2}(\mathrm{OH})_{3}\left(\mathrm{H}_{2} \mathrm{O}\right)_{7}\right]^{3+}+\left[\mathrm{Fe}(\mathrm{OH})\left(\mathrm{H}_{2} \mathrm{O}\right)_{5}\right]^{2+}} \\
\leftrightarrow\left[\mathrm{Fe}(\mathrm{OH})_{4}\left(\mathrm{H}_{2} \mathrm{O}\right)_{7}\right]^{5+}+2 \mathrm{H}_{2} \mathrm{O}
\end{gathered}
$$

709

710

711

Iron oxides are the final product of iron transformation in nature. In total, 16 known oxides and hydroxides exist [228], presented in Table 4, and a range among them has been used in heterogeneous catalysis processes, recently reviewed by Pouran et al. [219]. As the ferrous state of iron is highly prone to oxidation, oxides are a deterministic product of the evolution through time. Also, oxides derive from ferric iron as well. Therefore, there are $\mathrm{Fe}^{2+}$ and $\mathrm{Fe}^{3+}$-containing iron oxides, such as wüstite and goethite, respectively [218]. Jolivet et al. for instance have summarized the composition in $\mathrm{Fe}^{2+} /{ }^{3+}$ and hydroxylation ratio among the various iron oxides, indicating the existence of oxides with $\mathrm{Fe}^{2+}$ and $\mathrm{Fe}^{3+}$ in their composition [229]. 


\section{Oxide Hydroxides}

\begin{tabular}{|c|c|c|c|}
\hline \multirow{6}{*}{$\begin{array}{c}\text { Name } \\
\text { Goethite } \\
\text { Lepidocrocite } \\
\text { Akaganéite } \\
\text { Schwertmannite }\end{array}$} & & \\
\hline & Formula & Name & Formula \\
\hline & $\alpha-\mathrm{FeOOH}$ & Hematite & $\alpha-\mathrm{Fe}_{2} \mathrm{O}_{3}$ \\
\hline & $\gamma$-FeOOH & Magnetite & $\mathrm{Fe}_{3} \mathrm{O}_{4}\left(\mathrm{Fe}^{\mathrm{II}} \mathrm{Fe}_{2}^{\left.\mathrm{III} \mathrm{O}_{4}\right)}\right.$ \\
\hline & $\beta-\mathrm{FeOOH}$ & Maghemite & $\gamma-\mathrm{Fe}_{2} \mathrm{O}_{3}$ \\
\hline & $\mathrm{Fe}_{16} \mathrm{O}_{16}(\mathrm{OH})_{\mathrm{y}}\left(\mathrm{SO}_{4}\right)_{z} \bullet \mathrm{nH}_{2} \mathrm{O}$ & & $\beta-\mathrm{Fe}_{2} \mathrm{O}_{3}$ \\
\hline & $\delta-\mathrm{FeOOH}$ & & $\varepsilon-\mathrm{Fe}_{2} \mathrm{O}_{3}$ \\
\hline Feroxyhite & $\delta^{\prime}-\mathrm{FeOOH}$ & Wustite & $\mathrm{FeO}$ \\
\hline High pressure & $\mathrm{FeOOH}$ & & \\
\hline Ferrihydrite & $\mathrm{Fe}_{5} \mathrm{HO}_{8} \bullet 4 \mathrm{H}_{2} \mathrm{O}$ & & \\
\hline Bernalite & $\mathrm{Fe}(\mathrm{OH})_{3}$ & & \\
\hline Green rusts & $\begin{array}{c}\mathrm{Fe}(\mathrm{OH})_{2} \\
F e_{x}^{I I I} F e_{y}^{I I}(\mathrm{OH})_{3 x+2 y-z}\left(A^{-}\right)_{z}\end{array}$ & & \\
\hline
\end{tabular}

721 The different oxides can be formed according to the conditions present in the matrix; for instance for

$722 \mathrm{pH}>3$ hydroxylation of ferric ions can lead to ferrihydrate and hematite [229], or ferrous sulfate in

723 water has led to lepidocrocite and goethite [59]. A comprehensive list of the possible iron $\left(\mathrm{Fe}^{2+}\right.$ or $\mathrm{Fe}^{3+}$ )

724 to iron oxides can be found in Figure 6 [228]. Nevertheless, the significant/relevant interconversions

725 are the ones taking place in natural water, i.e. slightly acidic or basic conditions, presence of organic

726 matter, response to light etc. The initial conditions of the oxides formation on the other hand could

727 lead in the appearance of various forms of oxides in more special contexts; for instance mines or

728 volcanic soils, where temperatures and pressure could lead to transformations and subsequently, transfer of the oxides to surface waters. 


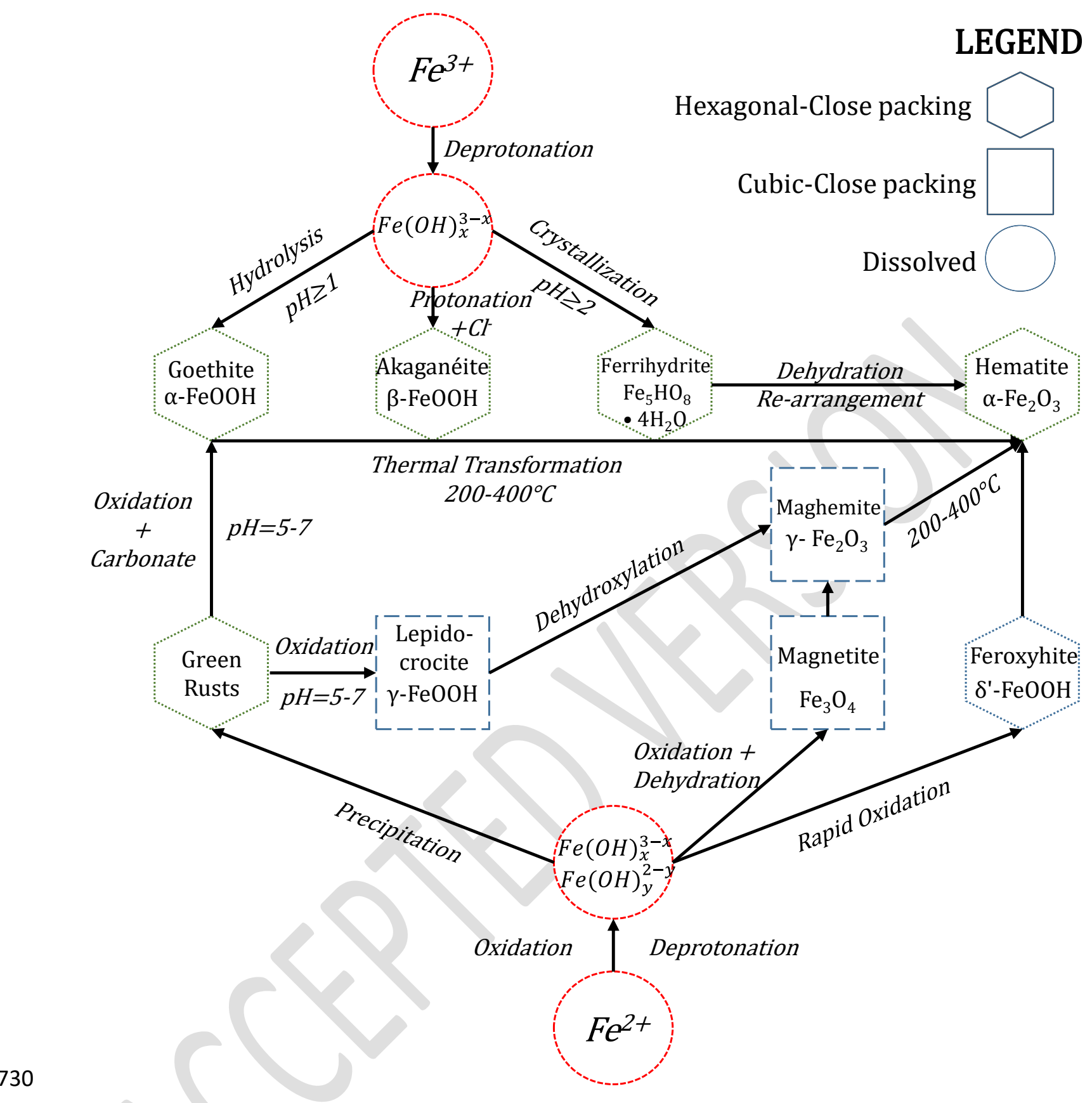

Figure 6 - Iron oxides formation and transformation (adapted from [228]). The different pathways of oxides transformation are presented, including both the ones taking place in natural waters, as well as the (theoretically) potentially present due to previous terrestrial properties. 


\begin{tabular}{|c|c|c|c|}
\hline Precursor & Product & Type of Transformation & Preferred medium \\
\hline \multirow{3}{*}{ Goethite } & Hematite & $\begin{array}{c}\text { Thermal or mechanical } \\
\text { dehydroxylation }\end{array}$ & Gas/Vacuum \\
\hline & Hematite & Hydrothermal dehydroxylation & Solution \\
\hline & Maghemite & Thermal dehydroxylation & Air + Organic \\
\hline \multirow{3}{*}{ Lepidocrocite } & $\begin{array}{l}\text { Maghemite/ } \\
\text { Hematite }\end{array}$ & Thermal dehydroxylation & Gas/Vacuum \\
\hline & Goethite & Dissolution/re-Precipitation & Alkaline Solution \\
\hline & Magnetite & Reduction & Alkaline Solution with $\mathrm{Fe}^{2+}$ \\
\hline \multirow{4}{*}{ Akaganéite } & Hematite & Thermal dehydroxylation & Gas/Vacuum \\
\hline & Goethite & Dissolution/re-Precipitation & Alkaline Solution \\
\hline & Hematite & Dissolution/re-Precipitation & Acid Solution \\
\hline & Magnetite & Dissolution/Reduction & Alkaline Solution with $\mathrm{N}_{2} \mathrm{H}_{4}$ \\
\hline$\delta-\mathrm{FeOOH}$ & Hematite & Thermal dehydroxylation & Gas/Vacuum \\
\hline Feroxyhyte & Goethite & Dissolution/re-Precipitation & Alkaline Solution \\
\hline \multirow{7}{*}{ Ferrihydrite } & $\begin{array}{l}\text { Maghemite } \\
\text { /Hematite }\end{array}$ & Thermal Dehydration/Dehydroxylation & Gas/Vacuum \\
\hline & Goethite & Dissolution/re-Precipitation & Aqueous Solution pH 3-14 \\
\hline & Akaganéite & Dissolution/re-Precipitation & Acidic Media $+\mathrm{Cl}$ \\
\hline & Lepidocrocite & Dissolution/re-Precipitation & $\mathrm{pH}=6+$ cysteine \\
\hline & Hematite & Aggregation & Aqueous Solution pH 6-8 \\
\hline & Hematite & $\begin{array}{l}\text { Short-Range Crystallization } \\
\text { with Ferrihydrite }\end{array}$ & Aqueous Solution pH 6-8 \\
\hline & $\begin{array}{l}\text { Substituted } \\
\text { Magnetite }\end{array}$ & Dissolution/re-Precipitation & Alkaline Solution + $\mathrm{M}^{\prime \prime}$ \\
\hline \multirow{2}{*}{ Hematite } & Magnetite & Reduction & Reducing gas \\
\hline & Magnetite & Reduction-Dissolution/re-Precipitation & Alkaline Solution with $\mathrm{N}_{2} \mathrm{H}_{4}$ \\
\hline Magnetite & $\begin{array}{l}\text { Maghemite/ } \\
\text { Hematite } \\
\end{array}$ & Oxidation & Air \\
\hline Maghemite & Hematite & Thermal Conversion & Air \\
\hline \multirow{5}{*}{$\mathrm{Fe}(\mathrm{OH})_{2}$} & Magnetite & Oxidation & $\mathrm{N}_{2}+$ alkaline solution \\
\hline & Goethite & & Alkaline Solution \\
\hline & Lepidocrocite & & \\
\hline & Magnetite & & \\
\hline & Maghemite & & \\
\hline $\mathrm{FeO}$ & Magnetite + Fe & Disproportionation & Air \\
\hline
\end{tabular}

Their solubility in water varies and depends on the composition of the matrix, as well as the properties of the oxide itself [230]. More specifically, the presence or absence of ligand, and the ionic strength, as well as the $\mathrm{pH}$ of the solution.

Table 6 [231] summarizes the $\mathrm{pH}$ for the zero point charge for the various oxides. This property is significant, as in natural waters and the corresponding $\mathrm{pH}$ values present, their contact with 
microorganisms could be either favored or prevented. Some other relevant properties, for their participation in the Fenton reaction is the crystallinity. This property is a good indicator of potential release of iron into the bulk and subsequent utilization in the homogeneous Fenton (-like) reaction. For instance, Ferrihydrite and Schwertmannite have low crystalline properties and they are expected to release more iron ions than oxides with similar content but high crystallinity [218].

Table 6-pH and isoelectric points of the various iron oxides (adapted from [231]).

\begin{tabular}{c|c} 
Sample & $\boldsymbol{p H}$ (point zero charge) \\
\hline $\mathrm{Fe}^{\mathrm{O}}$ & $7.8-8.1$ \\
$\mathrm{Fe}_{3} \mathrm{O}_{4}$ & $6.3-8.72$ \\
$\alpha-\mathrm{Fe}_{2} \mathrm{O}_{3}$ & $5.2-8.96$ \\
$\gamma-\mathrm{Fe}_{2} \mathrm{O}_{3}$ & 8.25 \\
$\alpha-\mathrm{FeOOH}$ & $7-9.5$ \\
$6-\mathrm{FeOOH}$ & $6.5-6.9$ \\
$\gamma-\mathrm{FeOOH}$ & $7.05-8.47$ \\
$\delta-\mathrm{FeOOH}$ & 8.5 \\
$\mathrm{Fe}_{5} \mathrm{HO}_{8} \cdot 4 \mathrm{H}_{2} \mathrm{O}$ & 8.9
\end{tabular}

Finally, of particularly high interest are the oxides which have oxidizing or good photochemical properties, like a- $\mathrm{Fe}_{2} \mathrm{O}_{3}, \mathrm{c}-\mathrm{Fe}_{2} \mathrm{O}_{3}$, a-Fe- $\mathrm{OOH}$, b-FeOOH and c-FeOOH. These oxides will be expected to contribute in the photo-enhanced Fenton reaction in near-neutral media [232, 233], actively participating either as sources of homogenous iron, heterogeneous catalysts or semiconductors.

\subsection{Iron, light supply and bacterial presence facilitate the photo-Fenton reaction}

Before the simultaneous presence of iron and $\mathrm{H}_{2} \mathrm{O}_{2}$ is further analyzed, the sole addition of iron will follow, as it can have bactericidal properties by itself. After the initial oxidation of $\mathrm{Fe}^{2+}$, the next steps of the process involve $\mathrm{Fe}^{3+}$-initiated reactions. $\mathrm{Fe}^{3+}$ is thermodynamically more stable than $\mathrm{Fe}^{2+}$, but is also less soluble [234]. Even at near-neutral pH, this is not a detrimental constraint, since $\mathrm{Fe}^{3+}$ can be reduced back to $\mathrm{Fe}^{2+}$ by different mechanisms. First of all, it must be noted that reduction process is in competition with precipitation. Since the iron-containing solids have big specific surface area [235] they can complex with ligands, or react with oxidants/reductants; electron transfer is facilitated and the aforementioned competitive processes. Therefore, the possible routes back to $\mathrm{Fe}^{2+}$, involve reduction of i) organically or inorganically complexed iron, ii) dissolved inorganic $\mathrm{Fe}^{3+}$, iii) 
microorganism-complexed iron and iv) matrix-assisted (i.e. thermal, abiotic) processes [236-242]. After its conversion back to $\mathrm{Fe}^{2+}$, even in small amounts, electron transfer is very fast, and iron is established as an efficient catalyst and a considerable electron source [235].

\subsubsection{Complexed iron: Organic, aqua- and aqua-hydroxy-complexes}

In principal, the available complexes are encountered in water through multiple routes, including precipitation, exchange with soils and urban activities [243-250]. One option is the carboxylate group (R-COO) which facilitates iron complexation. The polycarboxylates facilitate the photo-Fenton reaction, as they are photo-active under solar light, and initiate a number of Fenton-related actions [251]. Before we analyze the mechanism of reduction, we mention that some of the products of photo-reduction include the superoxide/hydroperoxide radical $\left(\mathrm{O}_{2}^{\bullet-} / \mathrm{HO}_{2}^{\bullet-}\right)$ and $\mathrm{H}_{2} \mathrm{O}_{2}[243,252]$; the photo-Fenton reaction is again initiated by $\mathrm{Fe}^{2+}$ and $\mathrm{H}_{2} \mathrm{O}_{2}$, and $\mathrm{HO}^{\bullet}$ are produced anew.

There are two mechanisms of iron regeneration under light, via either an inner or an outer electron transfer mechanism [253]. Firstly, the $\left[\mathrm{Fe}^{3+}-\mathrm{L}_{n}\right]$ is excited to $\left[\mathrm{Fe}^{3+}-\mathrm{L}_{n}\right]^{*}$ state, and i) via the inner-sphere mechanism $\mathrm{L}^{\bullet+}$ is formed, and $\left[\mathrm{Fe}^{2+}-\mathrm{L}_{\mathrm{n}-1}\right]$; In reaction with another ligand and oxygen the parent $\left[\mathrm{Fe}^{3+}-\right.$ $\left.L_{n}\right]$ is regenerated or ii) via an electron donor (which gets oxidized) the reaction of $\left[\mathrm{Fe}^{2+}-L_{n}\right]$ with molecular oxygen [253]. In both cases, a sacrificial electron donor is required and superoxide anion is formed, which, as analyzed before, has its own biological significance. Solar light is energetic enough to overpass the ligand-to-metal charge transfer (LMCT) band with only if the organic ligand is easily oxidized; in natural waters this is easy to get and therefore, this reaction is deeply meaningful.

The one-electron oxidation of the ligand generated within the process requires a second electron transfer to return to stable oxidation states, by the following reaction scheme:

$$
\begin{aligned}
& {\left[\mathrm{Fe}^{+3}-\mathrm{L}\right]^{3+}+2 \mathrm{H}_{2} \mathrm{O} \stackrel{h v(L M C T)}{\longrightarrow}\left[\mathrm{Fe}\left(\mathrm{H}_{2} \mathrm{O}\right)_{2}\right]^{2+}+L^{\bullet+}} \\
& L^{\bullet+}+\left[F e^{+3}-L\right]^{3+} \rightarrow\left[F e^{2+}-L\right]^{2+}+L^{2+} \\
& L^{\bullet+}+\mathrm{O}_{2} \rightarrow \mathrm{L}^{2+}+\mathrm{O}_{2}^{\bullet-} \\
& \mathrm{L}^{\bullet+}+\mathrm{Cu}^{2+} \rightarrow \mathrm{L}^{2+}+\mathrm{Cu}^{+}
\end{aligned}
$$

The oxidized ligand can react either by reaction a) with the parent $\mathrm{Fe}^{3+}-\mathrm{L}$ complex, b) with oxygen, creating superoxide radical anion) or c) with other oxidants in the matrix $[253,254]$. The unstable superoxide radical anion is leading to $\mathrm{H}_{2} \mathrm{O}_{2}$ formation or biological damage; it is therefore made clear that the photo-Fenton cycle by-products initiate more pathways towards bacterial inactivation. 
In other Fe-hydroxo complexes, there are similar pathways [232, 242], which can be summarized as:

$$
\begin{gathered}
{\left[\mathrm{Fe}^{3+} \mathrm{OH}_{n}\left(\mathrm{H}_{2} \mathrm{O}\right)_{6-n}\right]+\mathrm{H}_{2} \mathrm{O} \stackrel{h v(\mathrm{LMCT})}{\longrightarrow}\left[\mathrm{Fe}^{2+}\left(\mathrm{H}_{2} \mathrm{O}\right)_{6}\right]+\mathrm{HO}^{\bullet}} \\
{\left[\mathrm{Fe}^{2+}\left(\mathrm{H}_{2} \mathrm{O}\right)_{6}\right]+\mathrm{OH}^{-}+\mathrm{O}_{2} \rightarrow\left[\mathrm{Fe}^{3+} \mathrm{OH}_{n}\left(\mathrm{H}_{2} \mathrm{O}\right)_{6-n}\right]+\mathrm{H}_{2} \mathrm{O}}
\end{gathered}
$$

Among the two categories of ligands, only around $10-20 \%$ is waterbound, with the most abundant species, being the organically-complexed iron forms $[257,258]$.

\subsubsection{Iron-Microorganism interaction}

Iron holds the property of binding to surfaces which can provide the necessary electrostatic conditions. In the previous chapters, the chelating properties of organic ligands were presented and the water-iron complexes, as well as the iron inter-conversion in these cases. Although microorganisms are far more complex entities than organic compounds, there are some noteworthy properties that influence iron, such as: i) the overall solubility of iron in the matrix and ii) the iron formation within it.

Bacterial membranes consist in layers, which, on the outer surface, contain lipo-polysaccharide molecules (LPS). These LPS have been documented to bind bivalent molecules [259], and therefore offer binding sites to iron as well. The second macro-observation is that $\mathrm{Fe}^{3+}$ can form complexes with big macromolecules, which could mean that iron-bacteria aggregates can be formed [260]. As it is made clear, $\mathrm{Fe}^{2+}$ after its oxidation to $\mathrm{Fe}^{3+}$ can remain in suspension (even for a short period) and use the bacterial membrane as a ligand. Therefore, LMCT can occur, among the iron and the surface binding it [31]. As a result, reduction of $\mathrm{Fe}^{3+}$ takes place and the oxidation of the ligand, as it was described before, damages the external bacterial surface [50].

Even in absence of light, there were important observations of groups studying the iron oxides' interaction with bacteria [219, 261, 262], where different strains of both Gram negative or positive 
bacteria were found to be partially, up to fully covered in iron oxides. This could initiate a strong oxidative damage on the bacterial surface if the proper conditions are met. Also, another set of observations led to the influence of iron form if bacteria were present in a sample. It was shown [262] that letting the microorganisms age in a sample and allow the subsequent release of proteins and DNA (from dead cells) influenced the formation of specific iron oxide structures. As it appears, the iron oxides' formation is affected also by the presence of microorganisms, in a process called "oriented aggregation" $[263,264]$ apart from the $\mathrm{pH}$, temperature and oxygen constraints mentioned before.

\subsection{Homogeneous and heterogeneous Fenton, photo-Fenton and semiconductor} action mode, during simultaneous presence of hv, $\mathrm{H}_{2} \mathrm{O}_{2}$ and $\mathrm{Fe}$.

Continuing from the enhancement by $\mathrm{H}_{2} \mathrm{O}_{2}$, we assume now that iron is inserted into the photoinactivation process. $\mathrm{Fe}^{2+}$ in a previous chapter was subject to analyses and the presence of oxygen, in combination with $\mathrm{pH}$ were defined as the combined oxidation triggers. In a similar system, hydrogen peroxide can also determine the oxidation rate [265], converting $\mathrm{Fe}^{2+}$ to $\mathrm{Fe}^{3+}$. The ferrous ion is considerably more soluble, is readily oxidizable or assimilable by bacteria [266], but has lower complexing capabilities than $\mathrm{Fe}^{3+}$; considering the oxidative conditions present, it is not expected to remain long in this valence [265].

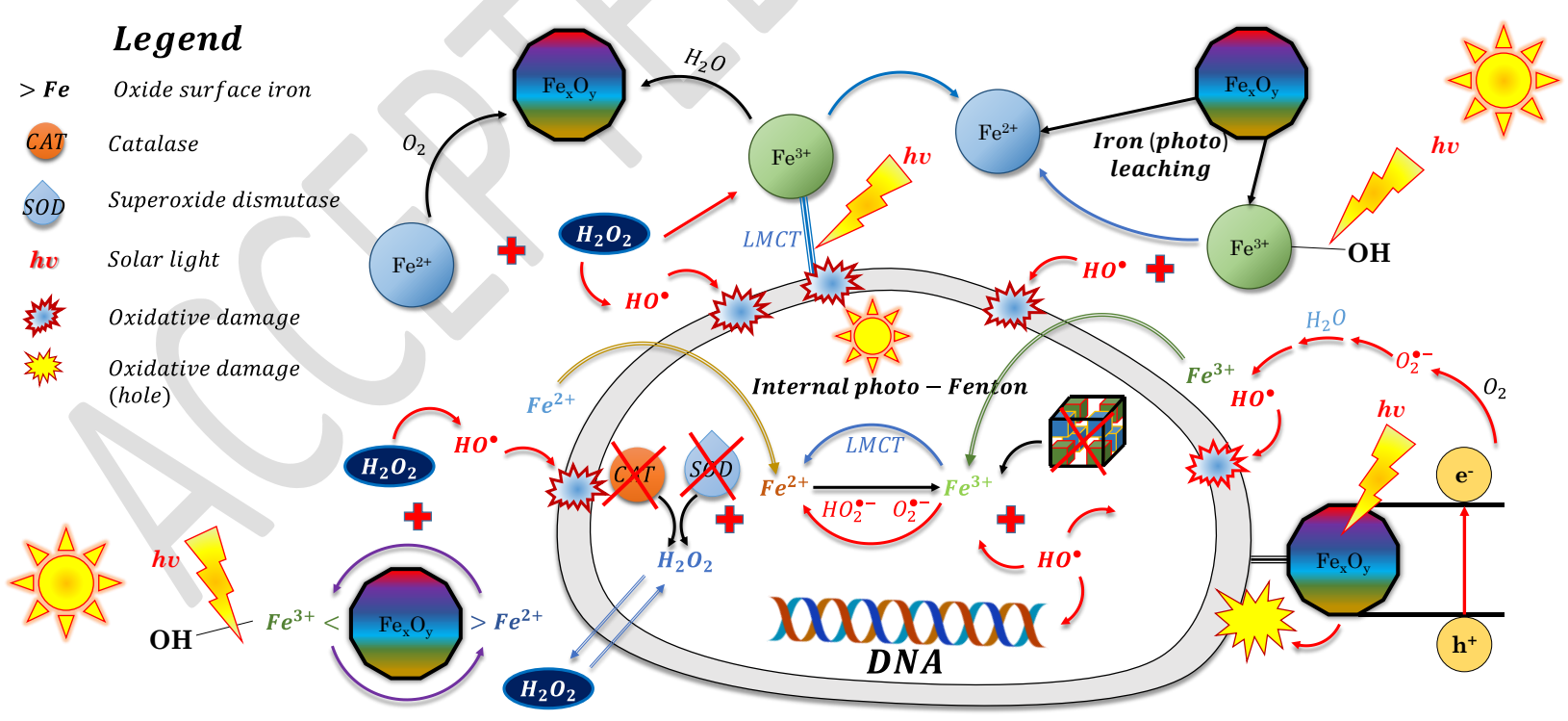
various actions are analyzed in-text, at steps 1-6. 
Nevertheless, the first step of the Fenton reaction is taking place efficiently, with simultaneous generation of $\mathrm{Fe}^{3+}$ and $\mathrm{HO}^{\bullet}$. In this part, we will attempt to concentrate the different photo-catalytic actions involved by the simultaneous addition of Fe salts and $\mathrm{H}_{2} \mathrm{O}_{2}$ and synthesize the inactivation mechanism dominating bacterial inactivation.

\section{Step 1: addition of $\mathrm{Fe}^{2+} \rightarrow$ internal action.}

$841 \mathrm{Fe}^{2+}$ addition, in absence of $\mathrm{H}_{2} \mathrm{O}_{2}$ in the water matrix, has itself limited reactivity. However, it can diffuse into the bacterial cell quite easily $[150,155]$ due to low charge density and difference in osmotic pressure between the cell and the matrix. From this point and onwards, it is available as a readily oxidizable catalyst, able to induce oxidative stress internally with the $\mathrm{H}_{2} \mathrm{O}_{2}$ produced as a normal part of the respiration chain. Considering an illuminated system, which, as we have analyzed, affects the regulation of ROS into the cell, the reaction with $\mathrm{H}_{2} \mathrm{O}_{2}$ becomes a photo-catalytic process; $\mathrm{Fe}^{3+}$ binds in various positions and uses a $\mathrm{LMCT}$ to regenerate back to $\mathrm{Fe}^{2+}$, or $\mathrm{O}_{2}^{--}$constantly releasing it from the Fe/S clusters around the cell.

$$
\begin{gathered}
\mathrm{Fe}^{2+}+\mathrm{H}_{2} \mathrm{O}_{2} \rightarrow \mathrm{Fe}^{3+}+\mathrm{HO}^{\bullet}+\mathrm{OH}^{-} \\
\mathrm{Fe}^{3+}+\mathrm{H}_{2} \mathrm{O}_{2} \rightarrow \mathrm{Fe}^{2+}+\mathrm{HO}_{2}^{\bullet}+\mathrm{H}^{+} \\
\mathrm{Fe}(\mathrm{OH})^{2+}+h v \rightarrow \mathrm{Fe}^{2+}+\mathrm{HO}^{\bullet} \\
{[\mathrm{Fe}(\mathrm{COO}-\mathrm{R})]^{2+}+h v \rightarrow \mathrm{Fe}^{2+}+\mathrm{CO}_{2}+\mathrm{R}^{\bullet}}
\end{gathered}
$$

849 This process has been proven of significant contribution $[31,50]$. The internal process has been found 850 to be important, when the internal and the external damage were compared through malondialdehyde (MDA) formation [50]. Both in bacteria [267] and in another microorganism (Saccharomyces cerevisiae) it was proven through proteomic analyses that internal photo-Fenton is the main driving force of its inactivation [71].

Step 2: addition of $\mathrm{Fe}^{2+} \rightarrow$ external action (including chelating agents).

$\mathrm{Fe}^{2+}$ addition, in presence of $\mathrm{H}_{2} \mathrm{O}_{2}$ in the matrix, can drive a homogeneous photo-Fenton process, for 856 a limited period of time. $\mathrm{Fe}^{2+}$ is soluble in water, and by reaction with $\mathrm{H}_{2} \mathrm{O}_{2}$, production of $\mathrm{HO}^{\bullet}$ is achieved in a big extent, effectively degrading the external cell membrane and resulting in microorganism degradation. However, we have analyzed the fate of $\mathrm{Fe}^{2+}$ in near-neutral $\mathrm{pH}$ and presence of dissolved oxygen and/or $\mathrm{H}_{2} \mathrm{O}_{2} ; \mathrm{Fe}^{3+}$ is expected to be formed, which in turn has limited dissolution rates in these conditions, except if it is complexed with organic ligands (its activity will be 
analyzed in step 3). In order to mitigate the problem of iron availability in unfavorable conditions, the use of chelating agents has been assessed for bacterial inactivation [68]. In this work, $\mathrm{Fe}^{2+}$ was provided by a stable (in the dark) Fe-citrate complex, whose light-initiated dissociation was as follows:

$$
\begin{gathered}
{\left[\mathrm{Fe}^{3+}-\text { citrate }\right]+h v \rightarrow \mathrm{Fe}^{2+}+\text { citrate }^{2 \bullet-}} \\
\text { citrate } \\
2 \bullet- \\
\mathrm{Fe}^{2+}+\mathrm{O}_{2} \rightarrow \text { product }+\mathrm{CO}_{2}+\mathrm{O}_{2}^{\bullet-} \\
\mathrm{Fe}^{3+}+\mathrm{O}_{2}^{\bullet-} \rightarrow \mathrm{Fe}^{2+}+\mathrm{O}_{2}
\end{gathered}
$$

Under irradiation of the photo-active complexes (main form at near-neutral pH: [FeHcit], [Fecit] ${ }^{-}$, $[\text { Fecit }]^{2-}$ and $[\text { FeHcit }]^{+}$, [Fecit], [FeOHcit] $]^{-}$for ferric and ferrous complexes, respectively) $\mathrm{Fe}^{2+}$ was released, according to the following reactions:

$$
\begin{gathered}
{[\mathrm{Fe}(\mathrm{OH})-\text { citrate }]^{-}+h v \stackrel{\text { LMCT }}{\longrightarrow} \mathrm{Fe}^{2+}+3-\mathrm{HGA}^{2 \bullet-}} \\
{\left[\mathrm{Fe}^{2+}-\text { citrate }\right]^{-}+\mathrm{H}_{2} \mathrm{O}_{2} \rightarrow\left[\mathrm{Fe}^{3+}-\text { citrate }\right]+\mathrm{OH}^{-}+\mathrm{HO}^{\bullet}} \\
\mathrm{HO}_{2}^{\bullet} \leftrightarrow \mathrm{O}_{2}^{\bullet-}+\mathrm{H}^{+}, \mathrm{pK}_{\mathrm{a}}=4.8 \\
\mathrm{HO}_{2}^{\bullet}+\mathrm{O}_{2}^{\bullet-}+\mathrm{H}_{2} \mathrm{O} \rightarrow \mathrm{H}_{2} \mathrm{O}_{2}+\mathrm{O}_{2}+\mathrm{OH}^{-} \\
\mathrm{HO}_{2}^{\bullet}+\mathrm{HO}_{2}^{\bullet} \rightarrow \mathrm{H}_{2} \mathrm{O}_{2}+\mathrm{O}_{2}
\end{gathered}
$$

Due to the presence of the ligand, effective bacterial inactivation was obtained up to $\mathrm{pH}=8.5$, by production of $\mathrm{HO}^{\bullet}$ and $\mathrm{O}_{2}^{\bullet-}$, measured by electron spin resonance (ESR) spectroscopy. The citrate by-products, as the ligands in the LMCT presented in previous chapters, can react with molecular oxygen or $\mathrm{H}_{2} \mathrm{O}_{2}$ to initiate further ROS production, mainly superoxide radical anion [18].

\section{Step 3: $\mathrm{Fe}^{3+}$ formation/addition (in presence of bacteria).}

$\mathrm{Fe}^{3+}$ has been shown to form after the oxidation of $\mathrm{Fe}^{2+}$, inside and outside the cell. Into the cell, upon formation $\mathrm{Fe}^{3+}$ can bind to proteins and DNA backbone, but efficiently participating in LMCT-initiated oxidative damage. $\mathrm{Fe}^{3+}$ can also play the role of electron acceptor during UV-affected dumping of electrons, during malfunctioning of the respiration process [31]. Furthermore, bacteria are known to produce siderophores such as (enterobactin, aerobactin, and ferrichrome), which are able to 
efficiently bind to $\mathrm{Fe}^{3+}$ and create complexes, therefore facilitating internal photo-assisted LMCT and 879 production of $\mathrm{HO}^{\bullet}$.

$$
\mathrm{Fe}^{3+}-\text { siderophore }+\mathrm{hv} \stackrel{\text { LMCT }}{\longrightarrow} \mathrm{Fe}^{2+}+L^{\bullet+}
$$

880 On the other hand, siderophores are not limited to internal activity, but, along with the bacterial 881 membranes, can facilitate external iron availability, as follows: the reduced diffusion capability of $\mathrm{Fe}^{3+}$ 882 is overpassed by transfer proteins, which bring $\mathrm{Fe}^{3+}$ into the cytoplasm. From this point it can play the 883 aforementioned roles. Outside the cell, $\mathrm{Fe}^{3+}$ binds to the bacterial membrane possessing high affinity 884 compounds, such as carboxylic groups [31] or phospholipids and lipo-polysaccharides [270] as 885 described in the previous chapter, forming Fe-bacterium complexes or $\mathrm{nFe}^{3+}$-mBacteria agglomerates. 886 The photo-initiated electron transfer by LMCT creates local, external oxidative damage and the 887 oxidized ligand could continue the oxidative chain reaction, producing more ROS. The production of 888 $\mathrm{Fe}^{2+}$ from this process re-initiates steps 1 and 2 .

\section{Step 4: Iron Oxides formation from $\mathrm{Fe}^{2+} / \mathrm{Fe}^{3+}$ addition.}

890 After conversion of $\mathrm{Fe}^{2+}$ to $\mathrm{Fe}^{3+}$, the Fenton process is considered as limited, since $\mathrm{Fe}(\mathrm{OH})^{2+}$ has limited 891 solubility at near-neutral pH and therefore, exploitation of its photoactivity is limited [50]. Instead, 892 zero-charge complexes are formed, such as $\mathrm{Fe}(\mathrm{OH})_{2}^{0}$, which are prone to oxidation and formation of 893 solid iron oxides, such as magnetite, goethite, lepidocrocite, or feroxyhyte [229]. Measurements have shown that iron precipitates as ferric oxide or hydroxide; formation of goethite and/or lepidocrocite $(\alpha-\mathrm{FeO}(\mathrm{OH})$ and $\gamma-\mathrm{FeO}(\mathrm{OH})$, respectively) [228]; this is why usually soluble iron precipitates after some time in Fenton experiments in near-neutral pH. As analyzed before, the formation of the oxides is affected by a number of parameters, and the different oxides could participate differently in the photo-catalytic inactivation mechanisms. The presence of $\mathrm{H}_{2} \mathrm{O}_{2}$ in the sample, as well as dissolved oxygen, normally initiates a series of reactions to create the oxides [59]:

$$
\begin{gathered}
\mathrm{Fe}^{2+}+6 \mathrm{H}_{2} \mathrm{O} \rightarrow\left[\mathrm{Fe}\left(\mathrm{H}_{2} \mathrm{O}\right)_{6}\right]_{(a q)}^{2+} \\
{\left[\mathrm{Fe}\left(\mathrm{H}_{2} \mathrm{O}\right)_{6}\right]_{(a q)}^{2+}+\mathrm{OH}^{-} \rightarrow\left[\mathrm{Fe}(\mathrm{OH})\left(\mathrm{H}_{2} \mathrm{O}\right)_{5}\right]_{(a q)}^{+}} \\
{\left[\mathrm{Fe}(\mathrm{OH})\left(\mathrm{H}_{2} \mathrm{O}\right)_{5}\right]_{(a q)}^{+}+\mathrm{OH}^{-} \rightarrow\left[\mathrm{Fe}(\mathrm{OH})_{2}\left(\mathrm{H}_{2} \mathrm{O}\right)_{4}\right]_{(a q)}} \\
\mathrm{Fe}^{2+}+\mathrm{O}_{2} \rightarrow \mathrm{Fe}^{3+}+\mathrm{O}_{2}^{\bullet-}
\end{gathered}
$$




$$
\begin{gathered}
\mathrm{Fe}(\mathrm{OH})^{+}+\mathrm{O}_{2} \rightarrow \mathrm{Fe}(\mathrm{OH})^{2+}+\mathrm{O}_{2}^{\bullet-} \\
\mathrm{Fe}(\mathrm{OH})_{2}+\mathrm{O}_{2} \rightarrow\left[\mathrm{Fe}(\mathrm{OH})_{2}\right]^{+}+\mathrm{O}_{2}^{\bullet-} \\
4\left[\mathrm{Fe}(\mathrm{OH})_{2}\left(\mathrm{H}_{2} \mathrm{O}\right)_{4}\right]_{(a q)} \rightarrow\left[\mathrm{Fe}_{4}(\mathrm{OH})_{8}\left(\mathrm{H}_{2} \mathrm{O}\right)_{8}\right]_{(s)}+8 \mathrm{H}_{2} \mathrm{O} \\
{\left[\mathrm{Fe}_{4}(\mathrm{OH})_{8}\left(\mathrm{H}_{2} \mathrm{O}\right)_{8}\right]_{(\mathrm{s})}+\mathrm{O}_{2} \rightarrow 4 \mathrm{FeOOH}(\mathrm{s})}
\end{gathered}
$$

900 Furthermore, iron oxides, depending on their isoelectric point (IEP), can adsorb to bacterial surfaces

901 [271, 272]; for instance, goethite, with an IEP between 7.6 and 8.9, is positively charged and its 902 connection with bacterial membrane, being negatively charged among pH 3 and 9 [270], is permitted. 903 In addition, Voelker et al. [273] have suggested also a small release of iron from the oxides. However, 904 in presence of bacteria, some of the iron oxides are chelated either by siderophores, bacterial surfaces 905 or bacterial degradation by-products. This increases the normally low solubility which these species 906 present at neutral pH. Even more, their simultaneous availability with $\mathrm{H}_{2} \mathrm{O}_{2}$ and/or light initiates the 907 next two mechanisms of inactivation, the semiconductor mode of action and the heterogeneous 908 catalyst effect.

\section{Step 5: Semiconductor action mode of iron oxides.}

910 Iron oxides can function as either heterogeneous photo-catalysts or as semiconductors. Although this 911 is not a step prior to the heterogeneous mechanism, but rather "a parallel" one, it will be presented 912 first, as this pathway can evolve, under condition, even without $\mathrm{H}_{2} \mathrm{O}_{2}$ addition.

913 Iron oxides, either naturally present in water [228] or laboratory-prepared [228] are among the most 914 reactive components within the matrix. Their chemical activity involves potential photocatalyst 915 activity, if the hole-electron recombination problem is overpassed [274]. The semiconductor action 916 mode is described by the following equations [228]:

$$
\begin{gathered}
\mathrm{Fe}_{2} \mathrm{O}_{3}+h v \rightarrow \mathrm{Fe}_{2} \mathrm{O}_{3}\left(e^{-}+h^{+}\right) \\
e_{(c b)}^{-}+\mathrm{O}_{2} \rightarrow \mathrm{O}_{2}^{\bullet-} \\
h_{(v b)}^{+}+\mathrm{O}^{\bullet-} \rightarrow{ }^{1} \mathrm{O}_{2} \\
e_{(c b)}^{-}+>\mathrm{Fe}^{3+} \rightarrow>\mathrm{Fe}^{2+} \\
h_{(v b)}^{+}+R X_{a d} \rightarrow R X_{a d}^{\bullet+}
\end{gathered}
$$




$$
\begin{aligned}
& e_{(c b)}^{-}+\mathrm{O}_{2}^{\bullet-}+2 \mathrm{H}^{+} \rightarrow \mathrm{H}_{2} \mathrm{O}_{2} \\
& e_{(c b)}^{-}+\mathrm{H}_{2} \mathrm{O}_{2} \rightarrow \mathrm{OH}^{-}+\mathrm{HO}^{\bullet}
\end{aligned}
$$

917 Briefly, the mechanism involves the absorption of a photon with higher energy than the band gap, generating hole-electron pairs in the conduction and valence bands, respectively. Assuming that there is a fraction of efficient promotion, rather than $100 \%$ recombination, redox reaction can take place in the surface of the oxide (marked as $>\mathrm{Fe}^{2+} /{ }^{3+}$ ) [59]. Light is essential to initiate the reaction [228, 275, $276]$ creating the hole-electron pairs. The conduction band produces electrons, which can initiate superoxide radical anion production, with molecular oxygen as electron acceptor, and either react with the holes to produce singlet oxygen, which has important biological significance, affect the external bacterial membrane themselves, or convert by-standing $\mathrm{Fe}^{3+}$ to $\mathrm{Fe}^{2+}[275,276]$. The holes, on the other hand can create oxidative damage to the bacterial membranes themselves, since their positive oxidation potential (1.7 at neutral pH), is under the redox potential of bacteria [276-279]. Another suggestion [276] proposes a scheme involving the production of $\mathrm{HO}^{\bullet}$ and $\mathrm{H}_{2} \mathrm{O}_{2}$. If $\mathrm{H}_{2} \mathrm{O}_{2}$ is added in the bulk, then higher $\mathrm{HO}^{\bullet}$ production is achieved, and therefore more significant bacterial inactivation.

Ruales-Lonfat et al. [59] tested 4 iron oxides, 3 of which revealed a semiconductor mode of action, goethite, hematite and wüstite; magnetite failed to demonstrate such capabilities in absence of $\mathrm{H}_{2} \mathrm{O}_{2}$, possibly due to low band gap, unfavorable IEP, high agglomeration [280] or high precipitation dynamics of the $\mathrm{Fe}^{2+}$ content $[281,282]$. In presence of bacteria, the siderophores affected the experiments, possibly by either enhancing dissolution of iron [269, 283, 284], electron transfer through LMCT in the Fe-siderophore complex, or a semiconductor-driven charge transfer of electron towards the oxide surface [284], leading to $\mathrm{Fe}^{3+}$ reduction.

\section{Step 6: Heterogeneous (photo)Fenton reaction.}

938 Iron oxides in presence of $\mathrm{H}_{2} \mathrm{O}_{2}$ can play the role of an efficient heterogeneous photo-catalyst, 939 towards, bacterial inactivation [50, 59], in two ways. Firstly, in presence of siderophores, it can 940 contribute to the supply of dissolved $\mathrm{Fe}^{2+}$ in the bulk [269]. Furthermore, $\mathrm{H}_{2} \mathrm{O}_{2}$ can start a series of 941 reactions, at which iron hydroxide ligands can get reduced, with simultaneous hydroperoxyl radical 942 formation [269]. Under light, the production of hydroxyl radicals is also favored [285]. The reactions involved are the following: 


$$
\begin{gathered}
>\mathrm{Fe}^{3+}-\mathrm{OH}+\mathrm{H}_{2} \mathrm{O}_{2} \rightarrow>\mathrm{Fe}^{2+}+\mathrm{HO}_{2}^{\bullet}+\mathrm{H}_{2} \mathrm{O} \\
>\mathrm{Fe}^{2+}+\mathrm{H}_{2} \mathrm{O}_{2} \rightarrow>\mathrm{Fe}^{3+}-\mathrm{OH}+\mathrm{HO}^{\bullet}+\mathrm{H}_{2} \mathrm{O} \\
>\mathrm{Fe}^{3+}-\mathrm{OH}+h v \rightarrow>\mathrm{Fe}^{2+}+\mathrm{HO}^{\bullet} \\
\mathrm{HO}_{2}^{\bullet} \leftrightarrow \mathrm{O}_{2}^{\bullet-}+H^{+}, \mathrm{pK}_{\mathrm{a}}=4.8 \\
>\mathrm{Fe}^{3+}-\mathrm{OH}+\mathrm{HO}_{2}^{\bullet} / \mathrm{O}_{2}^{\bullet-} \rightarrow>\mathrm{Fe}^{2+}+\mathrm{H}_{2} \mathrm{O} / \mathrm{OH}^{-}+\mathrm{O}_{2}
\end{gathered}
$$

944 As it is seems, even magnetite, which does not demonstrate semiconductor capabilities, was reported 945 to efficiently inactivate E. coli when $\mathrm{H}_{2} \mathrm{O}_{2}$ was added in the bulk [59]. In step 5, the formation of 946 quantities of $\mathrm{H}_{2} \mathrm{O}_{2}$ was also proposed, here we assess the possibility of $\mathrm{H}_{2} \mathrm{O}_{2}$ addition from the 947 beginning; then the preferred pathway for the oxides would be to use $\mathrm{H}_{2} \mathrm{O}_{2}$ as electron acceptor 948 (under light) or act as heterogeneous catalysts. The $\mathrm{H}_{2} \mathrm{O}_{2}$ accepting the electrons would further create $949 \mathrm{HO}^{\bullet}$ radicals, and further regeneration of $\mathrm{Fe}^{3+}$ back to $\mathrm{Fe}^{2+}$ would be achieved.

950 An alternative mechanism includes the disruption of the excited $>\mathrm{Fe}^{3+} \mathrm{OOH}$ bond, resulting to $>\mathrm{Fe}^{4+}=\mathrm{O}$ 951 species and $\mathrm{HO}^{\bullet}$ [286]. The latter reacts with water and further produces $\mathrm{HO} \bullet$ radicals; a summary of 952 the reaction scheme is as follows:

$$
\begin{aligned}
& >\mathrm{Fe}^{3+}-\mathrm{OH}+\mathrm{H}_{2} \mathrm{O}_{2} \rightarrow>\mathrm{Fe}^{2+}+\mathrm{HO}_{2}^{\bullet}+\mathrm{H}_{2} \mathrm{O} \\
& >\mathrm{Fe}^{3+}-\mathrm{OOH}+h v \rightarrow>\mathrm{Fe}^{4+}=\mathrm{O}+\mathrm{HO}^{\bullet} \\
& >\mathrm{Fe}^{4+}=\mathrm{O}+\mathrm{H}_{2} \mathrm{O} \rightarrow>\mathrm{Fe}^{3+}-\mathrm{OH}+\mathrm{HO}^{\bullet}
\end{aligned}
$$




\section{${ }_{954}$ Chapter IV: Influence of the water matrix}

956 1. Influence of natural organic matter on the photo-Fenton

957 reaction

958 The following conceptual part of this review assesses one of the most crucial components facilitating 959 the near-neutral photo-Fenton in natural waters, the presence of natural organic matter (NOM). Its 960 presence has been connected with both enhancement of the photo-Fenton reaction and partial 961 hindering, under circumstances. In this chapter, the various forms, functions and effects of NOM will 962 be presented.

963

\subsection{Definitions - Distinction among the components of NOM}

965

966

967

968

969

970

971

972

973

974

975

976

977

978

979

980

981

982

Natural organic matter (NOM) is a general definition, bringing together all types of organic matter normally present in natural water bodies. The two major categories of NOM, are the dissolved organic matter (DOM) and the particulate organic matter (POM). The distinction among the two categories is facilitated through a convention set in the isolation technique, i.e. filtering with 0.1-0.7 $\mu \mathrm{m}$ diameter membranes [287]; DOM is the fraction that is passing through, while POM is retained [288]. A number of authors have proposed further distinction, from the permate of ultrafiltration ( $<10 \mathrm{kDaltons})$, being the real dissolved organic matter, and the fraction above $10 \mathrm{kDa}$ and below 0.4 or $0.7 \mu \mathrm{m}$ the "total dissolved organic carbon". The colloidal sizes are among $1 \mathrm{~nm}$ and $1 \mu \mathrm{m}$, with the dissolved fraction being a part of it [289-293].

DOM is the result of material run-off from soils, the algal or phytoplankton originated biological byproducts from other surface waters, and the artificial, man-made substances that infiltrate natural waters; the three categories compose the allochthonous organic matter, varying from 10 to 300.000 kDa size [294-296]. However, there is a fraction of organic matter (OM) that is present and produced in the water body, the autochthonous part. Humic or fulvic substances, bacterial by-products, as well as organic acids, carbohydrates, proteins, lipids, alcohols, sterols and phenols are the rest of the major autochthonous fraction [288, 297-302]. Finally, the particulate organic matter (POM) is by definition larger in size and is composed by floral debris, bacterial and higher microorganisms' by-products and is also often a function of the neighboring soil properties [287]. 
984 The two main functions of DOM which facilitate its active participation in the photo-Fenton reaction are the photo-active behavior of certain moieties and its ability to complex metal cations, keeping them in solution and subsequently allow their participation in homogeneous oxido-reductive cycles, without suffering high degree of precipitation.

988

989

990

991

992

993

994

995

996

997

998

999

1000

1001

1002

1003

1004

1005

1006

1007

1008

1009

1010

1011

1012

1013

\subsubsection{Photo-activity: chromophoric and colored DOM}

In general, DOM is reported to absorb light in both UV and visible regions of light wavelengths [288, 299, 302-305]. The fundamental difference among colored and chromophoric DOM (CDOM) is the absorption in the visible region. The substances absorbing in the visible region are denoted as colored. Among the NOM, a differentiation could be made among the high and low molecular weight DOM constituents (HMW and LMW DOM). HMW DOM absorbs in a range of 250 to $800 \mathrm{~nm}$ and more specifically, the allochthonous fulvic and humic acids and the autocthnonous fulvic acids. The aforementioned substances are colored and can be marked as both colored and chromophoric DOM $[287,302,306-310]$. On the contrary, LMW DOM constituents absorb almost exclusively in the UV region and lack color. In detail, Mostofa et al. [287] have reviewed various components of the LMW DOM, such as formaldehyde, acetate, malonate and more, which absorb in 207-250 nm, 204-270 nm and $225-240 \mathrm{~nm}$, respectively. As no color is demonstrated, these substances are classified as chromophoric DOM, but not colored DOM.

\subsubsection{Complexation with trace metal ions}

The ability of DOM to complex metal ions is of critical importance in rendering metals available in the environment. This ability is exploited also by the natural cycle of photo-Fenton, further analyzed later. Their complexation is an indirect regulator of the overall chemistry of metal ions, affecting functions as transport, acid-base balance, solubility in water and more [287]. Among the DOM constituents, many of its components can participate in these functions, from both allochthonous and autochthonous fraction. More specifically, humic and fulvic substances, amino acids, extracellular polymeric substances produced by bacteria have demonstrated complexing capabilities [311, 312]. The diversity of the functional groups realize the complexation, with chromophoric and fluorophoric groups being among the most probable facilitators [288, 313-315]. Finally, the most important measure of the DOM-metal interaction is the conditional stability constant. This parameter has been reviewed by Mostofa et al. [287] and the most important parameters have been found to be the size (and origin) of $\mathrm{DOM}$, the matrix $\mathrm{pH}$, the cations and anions present, the photochemical processes 

of parameters, its value is expected to differ significantly.

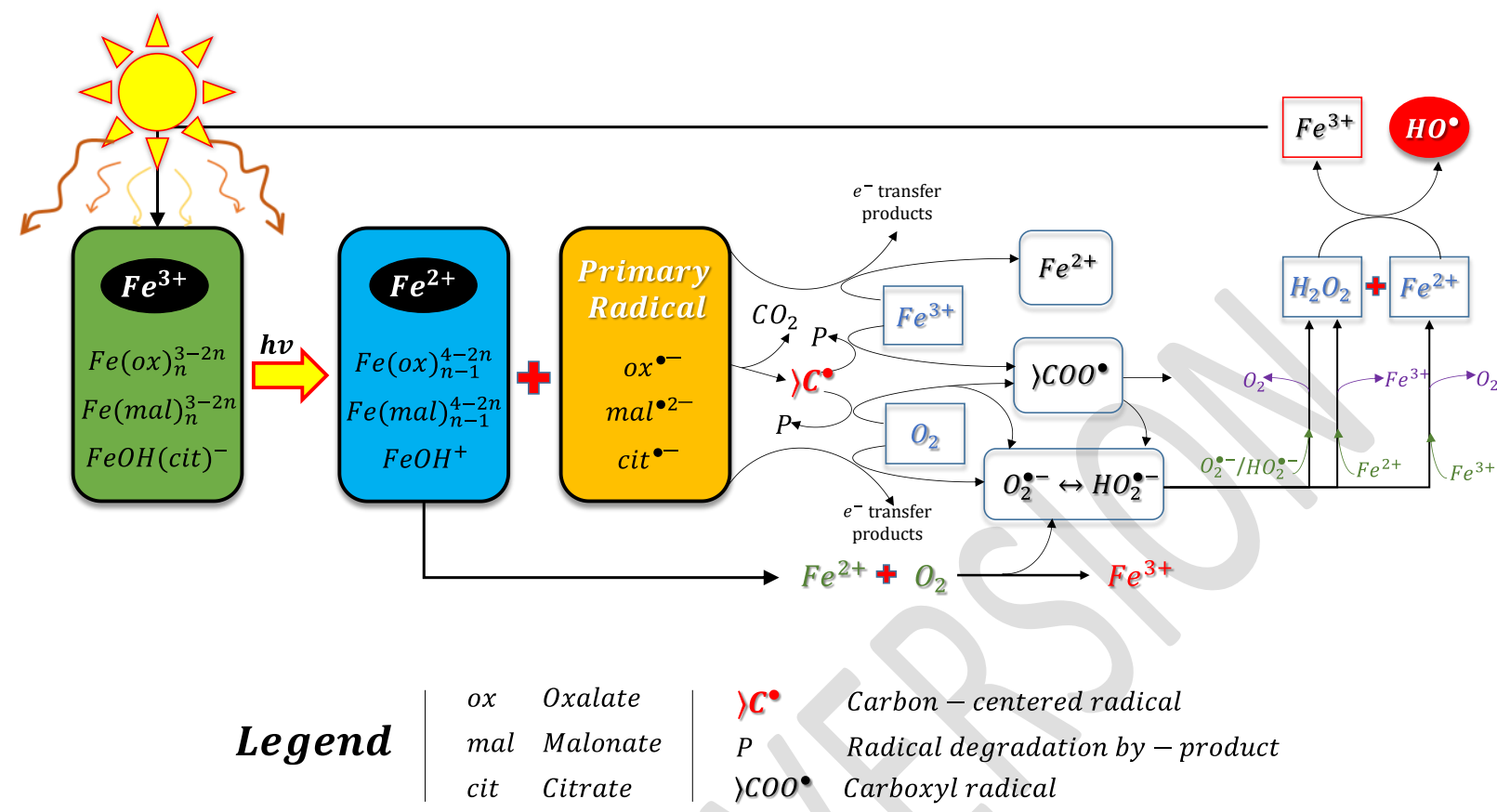

Figure 8 - Iron cycling in natural waters (adapted from [243]). The LMCT with oxalate, malonate and citrate complexes is presented, as indicative organic ligands of iron. Their photo-induced LMCT leads to reduced iron (blue panel) and ligand radicals (yellow panel). The ligand radicals initiate further oxidative-related reactions including the formation of $\mathrm{H}_{2} \mathrm{O}_{2}$, oxido-reduction of $\mathrm{Fe}$, and $\mathrm{HO}^{\bullet}$ generation.

\subsection{DOM photo-chemistry and the Fenton reaction.}

The interaction between DOM and light has been repeatedly reported to generate ROS in natural waters. Highly reactive $\mathrm{ROS}$, such as the hydroxyl radical $\left(\mathrm{HO}^{\bullet}\right)$ or less reactive/more selective, such as the superoxide radical anion $\left(\mathrm{O}_{2}^{\bullet-}\right)$, hydrogen peroxide $\left(\mathrm{H}_{2} \mathrm{O}_{2}\right)$, singlet oxygen $\left({ }^{1} \mathrm{O}_{2}\right)$, are generated in-situ, when DOM is irradiated. In this chapter, the generation of ROS, the implicated photo-chemistry and the dual role of DOM will be analyzed further.

Figure 8 summarizes the events that take place in natural waters, where the simultaneous presence of $\mathrm{Fe}, \mathrm{H}_{2} \mathrm{O}_{2}$ and $\mathrm{DOM}$ is expected. Measurements have indicated their co-existence in natural waters in USA [316-318], therefore in the case of solar irradiation, once again an in-situ photo-Fenton reaction is initiated. Adding iron and $\mathrm{H}_{2} \mathrm{O}_{2}$ will only enhance the photo-Fenton already taking place, aggravating the oxidative stress for the microorganisms present in water. The different events (1-14) are analyzed below: 
Event 1: Contribution of Particulate Organic Matter (POM).

Particulate organic matter has been identified to contribute in the overall photochemistry, producing singlet oxygen [319] but also is an indirect source of DOM for the bulk [320-324]. Therefore, it can be considered as input of DOM for the subsequent steps.

\section{Event 2: Direct photo-reactions of DOM with sunlight.}

In presence of organic matter, solar light is absorbed by DOM in the ground state and the excited singlet state is generated, leading to the conversion to the triplet state as explained in a previous chapter ( $\left.{ }^{3} \mathrm{DOM}^{*}\right)[325,326]$. The triplet state is an unstable form and will quickly react with molecular oxygen [327-331], with the result being singlet oxygen $\left({ }^{1} \mathrm{O}_{2}\right)$ production:

$$
\begin{gathered}
D O M+h v \rightarrow{ }^{1} D O M \rightarrow{ }^{3} D O M^{*} \\
{ }^{3} D^{*} M^{*}+O_{2} \rightarrow D O M+{ }^{1} O_{2}
\end{gathered}
$$

The termination of this reaction is reached with the return of DOM to its ground state. The singlet oxygen on the other hand will continue reacting (i.e. attacking bacteria), according to the schemes suggested in the previous chapters, or produce superoxide radical anions [332].

\section{Event 3: Triplet state energy transfer.}

The ${ }^{3} \mathrm{DOM}^{*}$ can react with ground state DOM present in water, including energy/electron transfer and/or hydrogen transfer [333]. The end-product of this reaction is the formation of DOM ${ }^{\bullet-}$ radicals and oxidized organic matter.

Event 4: Formation of $\mathrm{HO}_{2}^{\bullet} / \mathrm{O}_{2}^{\bullet-}$, as $\mathrm{H}_{2} \mathrm{O}_{2}$ precursors.

Continuing with energy/electron transfers, reaction of the DOM radical with molecular oxygen will induce the production of reactive transient species, precursors of ROS, such as $\mathrm{HO}_{2}^{\bullet} / \mathrm{O}_{2}^{\bullet-}$. The most important contribution of these transient species is derived by their dismutation, where $\mathrm{H}_{2} \mathrm{O}_{2}$ is formed [334-337]. During daytime, the maximal concentrations of $\mathrm{H}_{2} \mathrm{O}_{2}$ were measured [338]. The type of DOM did not seem to influence the $\mathrm{H}_{2} \mathrm{O}_{2}$ production [335, 339-343]. The initiator of the reaction is then oxidized. 
1076 1077

Iron can complex with the organic matter forming stable $\mathrm{Fe}^{3+}$-DOM species. Fe-DOM species are less prone to precipitation, plus have high absorption coefficients in near UV and visible range [260]; LMCT is therefore facilitated, between iron and DOM as a ligand. More specifically, below $450 \mathrm{~nm}$, Fe-humic complexes absorb light strongly [242, 273] and above $450 \mathrm{~nm}$ very few instances have been reported where efficient LMCT is taking place [265]. The reaction includes the reduction of iron and the oxidation of the participating ligand (DOM as ligand) as follows [344]:

$$
\left[\mathrm{Fe}^{3+}-\mathrm{DOM}\right]_{n}+h v \rightarrow\left[\mathrm{Fe}^{2+}-\mathrm{DOM}\right]_{(n-1)}+\mathrm{DOM}+\mathrm{Ox}^{+}
$$

Humic and fulvic acids can induce this reaction in the dark, but the reaction constant is greatly enhanced under illumination [236, 242, 345, 346]. Even more, the presence of oxalate or malonate offer even higher reaction constants [243].

\section{Event 6: The Fenton reaction.}

The Fenton reaction between the $\mathrm{Fe}^{2+}$ deriving from the $\mathrm{LMCT}$ and the $\mathrm{H}_{2} \mathrm{O}_{2}$ formed by the dismutation of hydroperoxyl and/or superoxide radicals leads to the production of $\mathrm{HO}^{\bullet}$ and $\mathrm{Fe}^{3+}[18,241,344,347$, $348]$. $\mathrm{Fe}^{3+}$ could re-complex with organic matter due to its strong electrophilic character.

\section{Event 7: Alternative $\mathrm{Fe}^{2+}$ oxidation pathways.}

Apart from the classical oxidation of $\mathrm{Fe}^{2+}$ to $\mathrm{Fe}^{3+}$ with $\mathrm{H}_{2} \mathrm{O}_{2}$ as oxidant, more pathways exist which result to $\mathrm{Fe}^{3+}$. Its reaction with $\mathrm{HO}_{2}^{\bullet} / \mathrm{O}_{2}^{\bullet-}$ will result to $\mathrm{Fe}^{3+}$ but actually catalyzes the production of $\mathrm{H}_{2} \mathrm{O}_{2}[273,338,349]$ :

$$
\mathrm{Fe}^{2+}+\mathrm{HO}_{2}^{\bullet} / \mathrm{O}_{2}^{\bullet-} \rightarrow \mathrm{Fe}^{3+}+\mathrm{H}_{2} \mathrm{O}_{2}
$$

The advantage of this process is the active replenishment of the $\mathrm{H}_{2} \mathrm{O}_{2}$ in the bulk, which aids the $\mathrm{HO}^{\bullet}$ production of Event 6.

\section{Event 8: Reduction of $\mathrm{Fe}^{3+}$ to $\mathrm{Fe}^{2+}$ (Non-LMCT pathway).}

Apart from the typical photo-Fenton-related pathways of iron reduction and re-initiation of the reactions, an alternative pathway has been reported. A reduced ligand L' reacts with dissolved $\mathrm{Fe}^{3+}$ producing $\mathrm{Fe}^{2+}[241]$ :

$$
\mathrm{Fe}^{3+}+L^{\prime} \rightarrow \mathrm{Fe}^{2+}+L_{\text {ox }}^{\prime}
$$


Other pathways include the reaction of $\mathrm{Fe}^{3+}$ with the amphoteric $\mathrm{HO}_{2}^{\bullet} / \mathrm{O}_{2}^{\bullet-}$, producing $\mathrm{Fe}^{2+}[240,241$, $243,265,273,350,351]$, in an inverse process compared with the one presented in event 7 :

$$
\mathrm{Fe}^{3+}+\mathrm{HO}_{2}^{\bullet} / \mathrm{O}_{2}^{\bullet-} \rightarrow \mathrm{Fe}^{2+}+\mathrm{O}_{2}
$$

The Fenton reaction could then be again initiated anew.

Event 9: Release of $\mathrm{Fe}^{2+} / \mathrm{Fe}^{3+}$ from iron oxides and vice-versa.

1086

1087

1088

1089

1090

1091

1092

1093

1094

1095

1096

1097

1098

1099

1100

1101

1102

1103

Voelker et al. [273] have included in the potential mechanisms the release of iron into the bulk, through iron oxides. This plausible mechanism will result to "readily available" or "complexable" iron. Since the presence of oxygen is highly probable and the $\mathrm{pH}$ of the majority of natural waters is circumneutral, the influence of the iron oxides is to be considered (and will further be assessed in next steps). Also, if microorganisms are present, chelating substances (siderophores) can aid the (photo)dissolution of iron oxides [284].

\section{Event 10: $\mathrm{Fe}^{2+}-\mathrm{Fe}^{3+}$ cycling at the surface of the iron oxide.}

$\mathrm{Fe}^{2+}$ at the surface of the iron oxide can react with the $\mathrm{H}_{2} \mathrm{O}_{2}$ formed in the bulk, producing $\mathrm{HO}^{\bullet}$ and $\mathrm{Fe}^{3+}$ [273]. This reaction can be important, in the case of encountering dissolved $\mathrm{Fe}^{2+}$ being unlikely [352].

\section{Event 11: DOM-Oxides complex.}

DOM can form complexes with the Fe oxides surface. More specifically, humic and carboxylate substances can form complexes with the surface of the oxides and participate in LMCT $[242,353]$. Similarly to the Fe-DOM complexes in the bulk, the result is reduction of $\mathrm{Fe}^{3+}$ in the surface of the oxide, with simultaneous $\mathrm{Fe}^{2+}$ and oxidized ligand production.

\section{Event 12: Reaction of DOM with molecular oxygen.}

A less reactive but nonetheless important reaction under concurrent illumination in presence of oxygen and DOM, is the reduction of dioxygen by CDOM, resulting to oxidized DOM and $\mathrm{HO}_{2}^{\bullet} / \mathrm{O}_{2}^{\bullet-}$, as follows [344]:

$$
\mathrm{DOM}+\mathrm{O}_{2}+h v \rightarrow D O M_{O x}^{+}+\mathrm{HO}_{2}^{\bullet} / \mathrm{O}_{2}^{\bullet-}
$$

The $\mathrm{HO}_{2}^{\bullet} / \mathrm{O}_{2}^{\bullet-}$ pair can then further regulate iron stoichiometry, as well as $\mathrm{H}_{2} \mathrm{O}_{2}$ production through dismutation. 
Apart from the role of facilitator, DOM can equally play the role of scavenger in the aquatic 1109 photochemistry implicated, as follows [325, 354, 355]:

$$
\mathrm{DOM}+\mathrm{HO}^{\bullet} \rightarrow \mathrm{DOM}_{\mathrm{Ox}}^{+}+\mathrm{HO}_{2}^{\bullet} / \mathrm{O}_{2}^{\bullet-}
$$

1110 As it can be understood, since the hydroxyl radicals are highly reactive and non-selective, their

1111 harnessing for bacterial inactivation only, is impossible. Side reactions, such as the present with DOM, or with $\mathrm{Fe}^{3+}$ (to reduce it to $\mathrm{Fe}^{2+}$ ) are bound to happen, but are a function of the type of DOM.

\section{Event 14: Restarting the DOM cycle.}

1114 The oxidized DOM and ligands most possibly do not stop their contribution at the moment of 1115 oxidation. It has been reported that $\mathrm{HO}^{\bullet}$ can inflict fragmentation of the humic acids in water [347], 1116 and end up in lower molecular weight organic compounds [239, 356-358]. These fragments can 1117 possibly re-complex with iron and further participate in the photo-chemical cycle. This process 1118 however is not infinite, and is macroscopically perceived as discoloration of CDOM, and this photobleaching engulfs the side-effect of decreased absorption coefficients of water [359, 360].

\subsection{The dual role of DOM}

1123 In many works, the presence of DOM in water has been found identified as an enhancement of the 1124 photo-Fenton reaction [27, 349, 361-369] [27, 349, 361-368, 370]. On the other hand, it has been also 1125 found to hinder the process [53, 371, 372]. Some authors suggested that the presence of humic substances inhibited [373-375] or had no significant effect [376-378] on the Fenton processes [365]. 


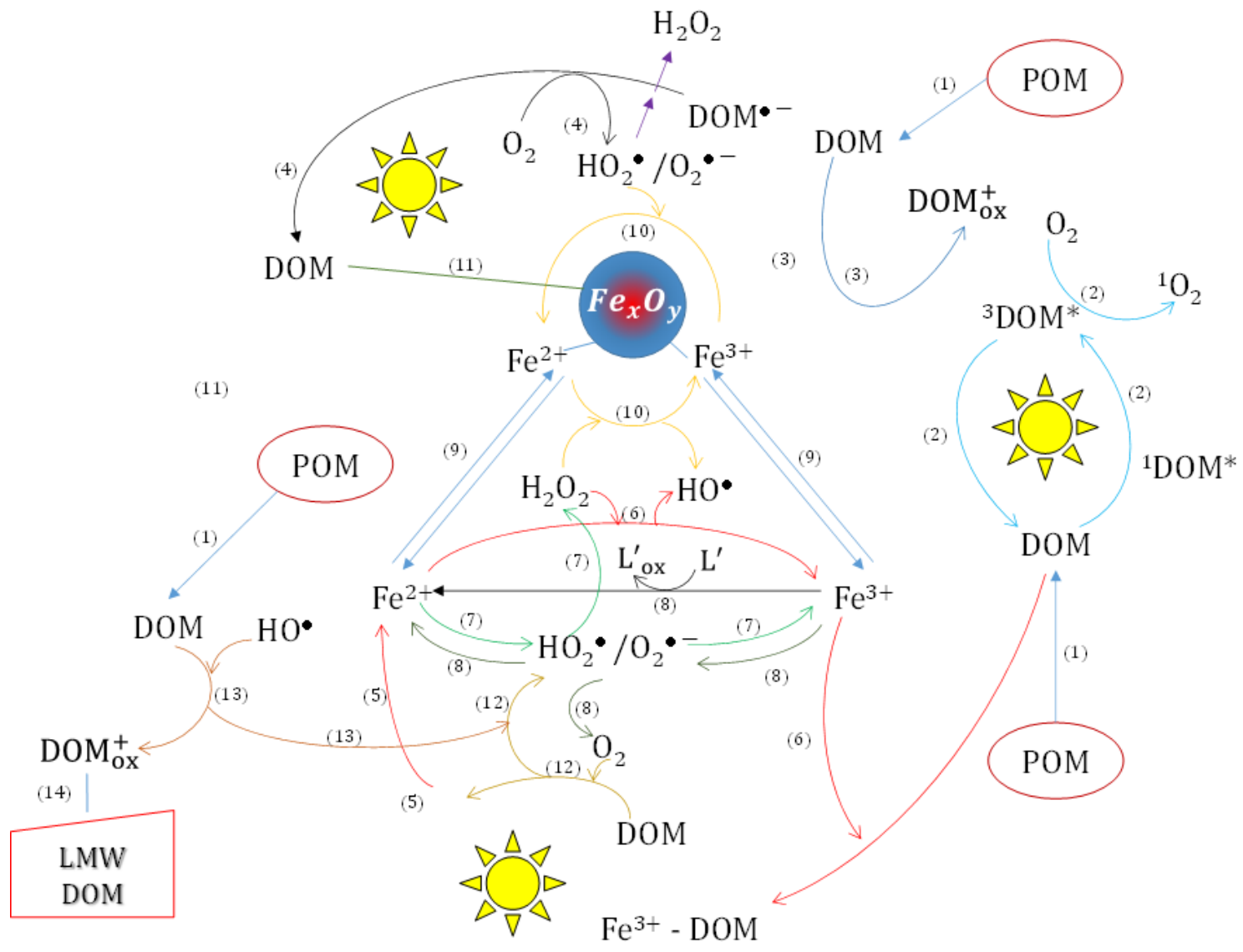

1128

Figure 9- Overall contribution of the natural water matrix and photochemical conversions. More detailed explanations can be found in-text, presented in events 1-14. DOM: Dissolved Organic Matter, ${ }^{1} D_{0}$ OM*:Singlet state DOM, ${ }^{3}$ DOM $^{*}$ : Triplet state DOM, DOM ox $^{+}$: Oxidized DOM, LMW DOM: Low molecular weight DOM, $\mathrm{L}^{\prime}$ : reduced ligand, $\boldsymbol{L}_{\text {ox }}^{\prime}$ : Oxidized reduced ligand, POM: Particulate Organic Matter.

In overall, the ability of DOM to enhance or inhibit the photo-Fenton reaction depends primarily on the complexation capabilities, the efficiency of $\mathrm{Fe}^{2+} / \mathrm{Fe}^{3+}$ cycling and the types of ROS produced during illumination [379]. As a principal, allochthonous fulvic acid is a less efficient ${ }^{3} \mathrm{DOM}^{*}$ producing DOM than autochthonous fulvic acid, while their ability to induce radicals is inversed [380]. Also, terrestrial DOM is inhibiting $\mathrm{HO}^{\bullet}$ production than the aquatic DOM [381], depending on their structure. Nevertheless, during solar disinfection of drinking water, the self-degradation of DOM is not a complete side-effect, since there is requirement to reduce the organics content; hence, the in-situ photo-Fenton reaction can achieve efficient disinfection and simultaneous DOM degradation/modification. 
Apart from the DOM-related interactions, the ROS formed during the previous process can either attack the microorganisms, the DOM itself (self-scavenging) or even anions and inorganic substances present in water. For instance, the $\mathrm{HO}^{\bullet}$ radicals formed can attack chloride ions, generating various chlorine radicals, such as ${ }^{\bullet} \mathrm{Cl}_{2},{ }^{\bullet} \mathrm{Cl}_{2}^{-}$, or $\mathrm{ClOH}$ [382]. Even more, hypochlorous acid can be formed from the reaction with $\mathrm{H}_{2} \mathrm{O}_{2}$. This would have the positive side-effect of inducing further inactivation. On the other hand, these reactions, or similar ones with bromine could potentially lead to halogenated by-products. Furthermore, the production of $\mathrm{HO}^{\bullet}$ has been linked with nitrite and nitrate photoreactions [383, 384]. The reaction scheme is as follows [385]:

$$
\begin{gathered}
\mathrm{NO}_{3}^{-}+\mathrm{H}^{+}+\mathrm{hv} \rightarrow \mathrm{HO}^{\bullet}+\bullet \mathrm{NO}_{2} \\
\mathrm{NO}_{3}^{-}+\mathrm{H}_{2} \mathrm{O}+\mathrm{hv} \rightarrow \mathrm{HO}^{\bullet}+\mathrm{NO}_{2}^{-}+\mathrm{OH}^{-} \\
\mathrm{NO}_{2}^{-}+\mathrm{H}_{2} \mathrm{O}+\mathrm{hv} \rightarrow \mathrm{HO}^{\bullet}+\mathrm{NO}+\mathrm{OH}^{-}
\end{gathered}
$$

1154 Also, photolysis of nitrogen-containing DOM is found to produce nitrite, as well as nitrate photolysis

1155 [369]. However, although nitrites are of less importance than nitrates in the overall photochemistry, 1156 their quantum yield is much higher [333]. The composition of the nitrogen-related compounds 1157 themselves is a dynamic process, changing during the photo-Fenton process, as it was reported [51], by the following reaction:

$$
\mathrm{NH}_{4}^{+} \leftrightarrow \mathrm{NH}_{3}+\mathrm{HO}^{\bullet} \rightarrow \mathrm{NH}_{2} \mathrm{OH} \rightarrow \mathrm{NOH} \rightarrow \mathrm{NO}_{2}^{-} \leftrightarrow \mathrm{NO}_{3}^{-}
$$

1159 The reaction then continues as Equations IV.9-11 indicate.

1160 Finally, the reaction of ROS with (bi)carbonates should not be overlooked, as they scavenge ROS, offering a protective effect on bacteria. $\mathrm{HCO}_{3}^{-}$itself absorbs light, shielding the microorganisms along with the ROS-scavenging effect [206, 386-388]. The reactions involved are as follows [47]:

$$
\begin{aligned}
& \mathrm{HO}^{\bullet}+\mathrm{HCO}_{3}^{-} \rightarrow{ }^{\bullet} \mathrm{CO}_{3}^{-}+\mathrm{H}_{2} \mathrm{O} \\
& \mathrm{HO}^{\bullet}+\mathrm{CO}_{3}^{2-} \rightarrow{ }^{\bullet} \mathrm{CO}_{3}^{-}+\mathrm{OH}^{-}
\end{aligned}
$$

1163 However, the importance of the organic matter, ions and inorganic matter will be further assessed in 1164 a wastewater matrix, where the weight and contribution in either scavenging or producing ROS will 

modifications are expected in wastewater.

1167 


\section{Provisional conclusions}

1171 In this review, we attempted to approach bacterial inactivation by the near-neutral photo-Fenton

1172 process in aqueous media, in an inside-out approach. We began by the description of the effect of 1173 light alone on different components of the bacterial cell (solar disinfection), followed by the individual 1174 responses of the Fenton reagents inside the bacteria, concluding with a contextualization in natural 1175 conditions.

1176 As solar light has been proven to play a key role in the process, a significant part of the review is 1177 devoted on the elucidation of its inactivation mechanisms, which in fact share common ground and 1178 overlap significantly with the Fenton process. As a matter of fact, it is here proven that solar 1179 disinfection is indeed a multi-level photo-Fenton process, internally and possibly in the exterior of the 1180 microorganism.

1181 In the following part of the review (Part 2), the applications on drinking water and wastewater are 1182 reviewed, presented in a critical way, thus differentiating the principal components involved in each 1183 of the two contexts. 
1186 [1] K. Barbusiński, Chemia, Dydaktyka, Ekologia, Metrologia 1 (2009) 111,112.

1187 [2] H. Fenton, Journal of the Chemical Society, Transactions 65 (1894) 899-910.

1188 [3] S. Goldstein, D. Meyerstein, G. Czapski, Free Radical Biology and Medicine 15 (1993) 435-445.

1189 [4] M. Masarwa, H. Cohen, D. Meyerstein, D.L. Hickman, A. Bakac, J.H. Espenson, Journal of the 1190 American Chemical Society 110 (1988) 4293-4297.

1191 [5] P. Wardman, L.P. Candeias, Radiation research 145 (1996) 523-531.

1192 [6] W.C. Bray, M.H. Gorin, Journal of the American Chemical Society 54 (1932) 2124-2125.

1193 [7] F. Haber, J. Weiss, The catalytic decomposition of hydrogen peroxide by iron salts, Proceedings 1194 of the Royal Society of London A: Mathematical, Physical and Engineering Sciences, The Royal Society, 1195 1934, pp. 332-351.

1196 [8] M. Kremer, Physical Chemistry Chemical Physics 1 (1999) 3595-3605.

1197 [9] W. Barb, J. Baxendale, P. George, K. Hargrave, Nature 163 (1949) 692-694.

1198 [10] J. Baxendale, M. Evans, C. Park, Transactions of the Faraday Society 42 (1946) 155-169.

1199 [11] C. Walling, Accounts of Chemical Research 8 (1975) 125-131.

1200 [12] C. Walling, G.M. Ei-Taliawi, Journal of the American Chemical Society 95 (1973) 844-847.

1201 [13] C. Walling, G. El-Taliawi, Journal of the American Chemical Society 95 (1973) 848-850.

1202 [14] C. Walling, R.A. Johnson, Journal of the American Chemical Society 97 (1975) 2405-2407.

1203 [15] C. Walling, R.A. Johnson, Journal of the American Chemical Society 97 (1975) 363-367.

1204 [16] C. Walling, S. Kato, Journal of the American Chemical Society 93 (1971) 4275-4281.

1205 [17] J.A. Imlay, S. Linn, Science 240 (1988) 1302-1309.

1206 [18] R.G. Zepp, B.C. Faust, J. Holgné, Environmental Science and Technology 26 (1992) 313-319.

1207 [19] R. Bauer, Chemosphere 29 (1994) 1225-1233.

1208 [20] J. Kiwi, C. Pulgarin, P. Peringer, M. Grätzel, Applied Catalysis B, Environmental 3 (1993) 85-99.

1209 [21] G. Ruppert, R. Bauer, G. Heisler, Chemosphere 28 (1994) 1447-1454.

1210 [22] M. Cho, Y. Lee, H. Chung, J. Yoon, Applied and environmental microbiology 70 (2004) 1129-

1213 [24] A.-G. Rincón, C. Pulgarin, Catalysis today 124 (2007) 204-214.

1214 [25] A.-G. Rincón, C. Pulgarin, Catalysis today 122 (2007) 128-136.

1215 [26] A. Moncayo-Lasso, R.A. Torres-Palma, J. Kiwi, N. Benítez, C. Pulgarin, Applied Catalysis B: 1216 Environmental 84 (2008) 577-583.

1217 [27] A. Moncayo-Lasso, J. Sanabria, C. Pulgarin, N. Benitez, Chemosphere 77 (2009) 296-300.

1218 [28] I. Kim, H. Tanaka, Environment international 35 (2009) 793-802.

1219 [29] F. Mazille, A. Moncayo-Lasso, D. Spuhler, A. Serra, J. Peral, N. Benítez, C. Pulgarin, Chemical 1220 Engineering Journal 160 (2010) 176-184.

1221 [30] F. Sciacca, J.A. Rengifo-Herrera, J. Wéthé, C. Pulgarin, Chemosphere 78 (2010) 1186-1191.

1222 [31] D. Spuhler, J. Andrés Rengifo-Herrera, C. Pulgarin, Applied Catalysis B: Environmental 96

[32] J.I. Nieto-Juarez, K. Pierzchła, A. Sienkiewicz, T. Kohn, Environmental science \& technology 44 (2010) 3351-3356.

[33] F. Sciacca, J.A. Rengifo-Herrera, J. Wéthé, C. Pulgarin, Solar Energy 85 (2011) 1399-1408.

[34] E.R. Bandala, L. González, F. De la Hoz, M.A. Pelaez, D.D. Dionysiou, P.S. Dunlop, J.A. Byrne, J.L. Sanchez, Journal of Photochemistry and Photobiology A: Chemistry 218 (2011) 185-191.

[35] A. Bernabeu, R. Vicente, M. Peribáñez, A. Arques, A. Amat, Chemical engineering journal 171 (2011) 490-494.

[36] E. Ortega-Gomez, P. Fernandez-Ibanez, M.M. Ballesteros Martin, M.I. Polo-Lopez, B. Esteban Garcia, J.A. Sanchez Perez, Water research 46 (2012) 6154-6162.

1233 [37] A. Moncayo-Lasso, L.E. Mora-Arismendi, J.A. Rengifo-Herrera, J. Sanabria, N. Benítez, C. Pulgarin, Photochemical and Photobiological Sciences 11 (2012) 821-827. 
[38] M.I. Polo-López, I. García-Fernández, T. Velegraki, A. Katsoni, I. Oller, D. Mantzavinos, P. Fernández-Ibáñez, Applied Catalysis B: Environmental 111 (2012) 545-554.

[39] N. Klamerth, S. Malato, A. Agüera, A. Fernández-Alba, G. Mailhot, Environmental Science \& Technology 46 (2012) 2885-2892.

[40] I. García-Fernández, M. Polo-López, I. Oller, P. Fernández-lbáñez, Applied Catalysis B: Environmental 121 (2012) 20-29.

[41] E.R. Bandala, L. González, J.L. Sanchez-Salas, J.H. Castillo, Journal of Water and Health 10 (2012) 20-30.

[42] J. Rodríguez-Chueca, M. Morales, R. Mosteo, M. Ormad, J. Ovelleiro, Photochemical \& Photobiological Sciences 12 (2013) 864-871.

[43] E. Ortega-Gómez, B. Esteban García, M.M. Ballesteros Martín, P. Fernández Ibáñez, J.A. Sánchez Pérez, Catalysis Today 209 (2013) 195-200.

[44] J.I. Nieto-Juarez, T. Kohn, Photochemical \& Photobiological Sciences 12 (2013) 1596-1605.

[45] J. Ndounla, D. Spuhler, S. Kenfack, J. Wéthé, C. Pulgarin, Applied Catalysis B: Environmental 129 (2013) 309-317.

[46] M. Agulló-Barceló, M. Polo-López, F. Lucena, J. Jofre, P. Fernández-Ibáñez, Applied Catalysis B: Environmental 136 (2013) 341-350.

[47] D. Rubio, E. Nebot, J.F. Casanueva, C. Pulgarin, Water research 47 (2013) 6367-6379.

[48] M.I. Polo-López, I. Oller, P. Fernández-Ibáñez, Catalysis Today 209 (2013) 181-187.

[49] C. Ruales-Lonfat, A.V. López, J.F. Barona, A. Moncayo-Lasso, N.B. Vásquez, C. Pulgarín, Technologies for Sustainable Development, Springer, 2014, pp. 113-128.

[50] C. Ruales-Lonfat, N. Benítez, A. Sienkiewicz, C. Pulgarín, Applied Catalysis B: Environmental 160 (2014) 286-297.

[51] J. Ndounla, C. Pulgarin, Science of the Total Environment 493 (2014) 229-238.

[52] J. Ndounla, S. Kenfack, J. Wéthé, C. Pulgarin, Applied Catalysis B: Environmental 148-149 (2014) 144-153.

[53] E. Ortega-Gómez, M.M. Ballesteros Martín, B. Esteban García, J.A. Sánchez Pérez, P. Fernández Ibáñez, Applied Catalysis B: Environmental 148-149 (2014) 484-489.

[54] E. Ortega-Gómez, B.E. García, M.B. Martín, P.F. Ibáñez, J.S. Pérez, Water research 63 (2014) 316-324.

[55] A. Teodoro, M.Á. Boncz, A.M. Júnior, P.L. Paulo, Journal of Environmental Chemical Engineering 2 (2014) 958-962.

[56] J. Rodríguez-Chueca, A. Mediano, M. Ormad, R. Mosteo, J. Ovelleiro, Water research 60 (2014) 250-258.

[57] J. Rodríguez-Chueca, M. Polo-López, R. Mosteo, M. Ormad, P. Fernández-Ibáñez, Applied Catalysis B: Environmental 150 (2014) 619-629.

[58] M.I. Polo-López, M. Castro-Alférez, I. Oller, P. Fernández-Ibáñez, Chemical Engineering Journal 257 (2014) 122-130.

[59] C. Ruales-Lonfat, J.F. Barona, A. Sienkiewicz, M. Bensimon, J. Vélez-Colmenares, N. Benítez, C. Pulgarín, Applied Catalysis B: Environmental 166-167 (2015) 497-508.

[60] S. Giannakis, S. Papoutsakis, E. Darakas, A. Escalas-Cañellas, C. Pétrier, C. Pulgarin, Ultrasonics sonochemistry 22 (2015) 515-526.

[61] E. Ortega-Gómez, M.M. Ballesteros Martín, A. Carratalà, P. Fernández Ibañez, J.A. Sánchez Pérez, C. Pulgarín, Applied Catalysis B: Environmental 174-175 (2015) 395-402.

[62] S. Barreca, J.J. Velez Colmenares, A. Pace, S. Orecchio, C. Pulgarin, Journal of Environmental Chemical Engineering 3 (2015) 317-324.

[63] C. Pulgarin, CHIMIA International Journal for Chemistry 69 (2015) 7-9.

[64] J. Ndounla, C. Pulgarin, Environ Sci Pollut Res (2015) 1-13.

[65] J. Rodríguez-Chueca, M.P. Ormad, R. Mosteo, J.L. Ovelleiro, Chemical Engineering Science 138 (2015) 730-740. 
[66] J. Rodríguez-Chueca, M.P. Ormad, R. Mosteo, J. Sarasa, J.L. Ovelleiro, Water Environment Research 87 (2015) 281-288.

[67] V. Aurioles-López, M.I. Polo-López, P. Fernández-Ibáñez, A. López-Malo, E.R. Bandala, Physics and Chemistry of the Earth, Parts A/B/C (2015).

[68] C. Ruales-Lonfat, J.F. Barona, A. Sienkiewicz, J. Vélez, L.N. Benítez, C. Pulgarín, Applied Catalysis B: Environmental 180 (2016) 379-390.

[69] A. Ruiz-Aguirre, M.I. Polo-López, P. Fernández-Ibáñez, G. Zaragoza, Desalination and Water Treatment 55 (2015) 2792-2799.

[70] E. Ortega-Gómez, M.B. Martín, B.E. García, J.S. Pérez, P.F. Ibáñez, Applied Catalysis B: Environmental 181 (2016) 1-6.

[71] S. Giannakis, C. Ruales-Lonfat, S. Rtimi, S. Thabet, P. Cotton, C. Pulgarin, Applied Catalysis B: Environmental 185 (2016) 150-162.

[72] R.B. Setlow, Proceedings of the National Academy of Sciences 71 (1974) 3363-3366.

[73] E.G. Mbonimpa, B. Vadheim, E.R. Blatchley, 3rd, Water research 46 (2012) 2344-2354.

[74] R. Bensasson, E. Land, T. Truscott, Excited states and free radicals in biology and medicine: contributions from flash photolysis and pulse radiolysis, Tokyo, 1993.

[75] D.I. Pattison, M.J. Davies, Cancer: cell structures, carcinogens and genomic instability, Springer, 2006, pp. 131-157.

[76] H. Black, P. Forbes, J. Cleaver, H. Ananthaswamy, S. Ullrich, R. Tyrrell, Journal of Photochemistry and Photobiology B: Biology 40 (1997) 29-47.

[77] J. Cadet, C. Anselmino, T. Douki, L. Voituriez, Journal of Photochemistry and Photobiology B: Biology 15 (1992) 277-298.

[78] J.-L. Ravanat, T. Douki, J. Cadet, Journal of Photochemistry and Photobiology B: Biology 63 (2001) 88-102.

[79] R.P. Sinha, D.-P. Häder, Photochemical \& Photobiological Sciences 1 (2002) 225-236.

[80] T. Douki, G. Laporte, J. Cadet, Nucleic acids research 31 (2003) 3134-3142.

[81] D.L. MITCHELL, R.S. NAIRN, Photochemistry and photobiology 49 (1989) 805-819.

[82] G.P. Pfeifer, Photochemistry and photobiology 65 (1997) 270-283.

[83] G.P. Pfeifer, Y.-H. You, A. Besaratinia, Mutation Research/Fundamental and Molecular Mechanisms of Mutagenesis 571 (2005) 19-31.

[84] J.-H. Yoon, C.-S. Lee, T.R. O'Connor, A. Yasui, G.P. Pfeifer, Journal of molecular biology 299 (2000) 681-693.

[85] J.S. Taylor, M.P. Cohrs, Journal of the American Chemical Society 109 (1987) 2834-2835.

[86] J.S. Taylor, H.F. Lu, J.J. Kotyk, Photochemistry and photobiology 51 (1990) 161-167.

[87] K. Wierzchowski, D. Shugar, Acta Biochimica Polonica 8 (1960) 219-234.

[88] T. Douki, J. Cadet, Biochemistry 40 (2001) 2495-2501.

[89] J.M. Song, J. Milligan, B.M. Sutherland, Biochemistry 41 (2002) 8683-8688.

[90] M.J. Davies, Biochemical and biophysical research communications 305 (2003) 761-770.

[91] A. Eisenstark, Mutation Research/Fundamental and Molecular Mechanisms of Mutagenesis 422 (1998) 85-95.

[92] H.-L. Lo, S. Nakajima, L. Ma, B. Walter, A. Yasui, D.W. Ethell, L.B. Owen, BMC cancer 5 (2005) 135.

[93] W.P. Roos, B. Kaina, Trends in molecular medicine 12 (2006) 440-450.

[94] O. Sidorkina, S. Kuznetsov, J. Blais, M. Bazin, J. Laval, R. Santus, Photochemistry and photobiology 69 (1999) 658-663.

[95] M.J. Davies, R.J. Truscott, Journal of Photochemistry and Photobiology B: Biology 63 (2001) 114-125.

[96] Y. Matsumura, H.N. Ananthaswamy, Toxicology and applied pharmacology 195 (2004) 298308.

[97] T. Douki, A. Reynaud-Angelin, J. Cadet, E. Sage, Biochemistry 42 (2003) 9221-9226. 
[98] P.J. Rochette, J.P. Therrien, R. Drouin, D. Perdiz, N. Bastien, E.A. Drobetsky, E. Sage, Nucleic acids research 31 (2003) 2786-2794.

[99] A. Besaratinia, T.W. Synold, H.-H. Chen, C. Chang, B. Xi, A.D. Riggs, G.P. Pfeifer, Proceedings of the National Academy of Sciences of the United States of America 102 (2005) 10058-10063.

[100] L.F. Batista, B. Kaina, R. Meneghini, C.F. Menck, Mutation Research/Reviews in Mutation Research 681 (2009) 197-208.

[101] Y. Jiang, M. Rabbi, M. Kim, C. Ke, W. Lee, R.L. Clark, P.A. Mieczkowski, P.E. Marszalek, Biophysical journal 96 (2009) 1151-1158.

[102] S. Mouret, C. Philippe, J. Gracia-Chantegrel, A. Banyasz, S. Karpati, D. Markovitsi, T. Douki, Organic \& biomolecular chemistry 8 (2010) 1706-1711.

[103] A. Emrick, J. Sutherland, Photochem. Photobiol 49 (1989) 35S.

[104] S.E. Freeman, H. Hacham, R. Gange, D. Maytum, J.C. Sutherland, B. Sutherland, Proceedings of the National Academy of Sciences 86 (1989) 5605-5609.

[105] H. Hacham, S.E. Freeman, R.W. Gange, D.J. Maytum, J.C. Sutherland, B.M. Sutherland, Photochemistry and photobiology 52 (1990) 893-896.

[106] F. Quaite, B.M. Sutherland, J.C. Sutherland, Nature 358 (1992) 576-578.

[107] J. Cadet, E. Sage, T. Douki, Mutation Research/Fundamental and Molecular Mechanisms of Mutagenesis 571 (2005) 3-17.

[108] J. Cadet, M. Berger, T. Douki, B. Morin, S. Raoul, J. Ravanat, S. Spinelli, Biological chemistry 378 (1997) 1275-1286.

[109] C.S. Foote, Photochemistry and photobiology 54 (1991) 659-659.

[110] J. Cadet, R. Teoule, Photochemistry and photobiology 28 (1978) 661-665.

[111] C. Sheu, C.S. Foote, Journal of the American Chemical Society 115 (1993) 10446-10447.

[112] J. Hoerter, A. Pierce, C. Troupe, J. Epperson, A. Eisenstark, Photochemistry and photobiology 64 (1996) 537-541.

[113] E. Smyk-Randall, O. Brown, A. Wilke, A. Eisenstark, D. Flint, Free Radical Biology and Medicine 14 (1993) 609-613.

[114] C. Kielbassa, L. Roza, B. Epe, Carcinogenesis 18 (1997) 811-816.

[115] D.E. Heck, M. Shakarjian, H.D. Kim, J.D. Laskin, A.M. Vetrano, Annals of the New York Academy of Sciences 1203 (2010) 120-125.

[116] D.E. Heck, A.M. Vetrano, T.M. Mariano, J.D. Laskin, Journal of Biological Chemistry 278 (2003) 22432-22436.

[117] A. Eisenstark, G. Perrot, Molecular and General Genetics MGG 207 (1987) 68-72.

[118] S. Kawanishi, T. Hiraku, Oxidants and Antioxidants in Cutaneous Biology. Curr Probl Dermatol. Basel: Karger 29 (2001) 74-82.

[119] J.L. Ravanat, C. Saint-Pierre, P. Di Mascio, G.R. Martinez, M.H. Medeiros, J. Cadet, Helvetica chimica acta 84 (2001) 3702-3709.

[120] J. Cadet, T. Douki, J.-L. Ravanat, P. Di Mascio, Photochemical \& Photobiological Sciences 8 (2009) 903-911.

[121] A.L. Santos, V. Oliveira, I. Baptista, I. Henriques, N.C. Gomes, A. Almeida, A. Correia, Â. Cunha, Archives of microbiology 195 (2013) 63-74.

[122] F. Bosshard, M. Bucheli, Y. Meur, T. Egli, Microbiology 156 (2010) 2006-2015.

[123] J.A. Imlay, Annual Reviews in Microbiology 57 (2003) 395-418.

[124] A. Ligeza, A.N. Tikhonov, J.S. Hyde, W.K. Subczynski, Biochimica et Biophysica Acta (BBA)Bioenergetics 1365 (1998) 453-463.

[125] V. Massey, S. Strickland, S.G. Mayhew, L.G. Howell, P. Engel, R.G. Matthews, M. Schuman, P. Sullivan, Biochemical and biophysical research communications 36 (1969) 891-897.

[126] J.A. Imlay, Annual review of biochemistry 77 (2008) 755.

[127] P.M. Wood, Biochemical Journal 253 (1988) 287-289.

[128] B. González-Flecha, B. Demple, Journal of Biological Chemistry 270 (1995) 13681-13687.

[129] J. Imlay, I. Fridovich, Journal of Biological Chemistry 266 (1991) 6957-6965. 

Hotchkiss, T.J. Fleming, S. Johnson, Journal of Photochemistry and Photobiology B: Biology 81 (2005) 171-180.

[135] P. Chelikani, I. Fita, P.C. Loewen, Cellular and Molecular Life Sciences CMLS 61 (2004) 192-208. [136] J. Cadet, IARC scientific publications (1993) 245-276.

[137] J. Cadet, T. Delatour, T. Douki, D. Gasparutto, J.-P. Pouget, J.-L. Ravanat, S. Sauvaigo, Mutation Research/Fundamental and Molecular Mechanisms of Mutagenesis 424 (1999) 9-21.

[138] J.M. McCord, I. Fridovich, Journal of Biological chemistry 244 (1969) 6049-6055.

[139] S.S. Korshunov, J.A. Imlay, Molecular microbiology 43 (2002) 95-106.

[140] R.E. Lynch, I. Fridovich, Journal of Biological Chemistry 253 (1978) 4697-4699.

[141] S. Burney, J.L. Caulfield, J.C. Niles, J.S. Wishnok, S.R. Tannenbaum, Mutation Research/Fundamental and Molecular Mechanisms of Mutagenesis 424 (1999) 37-49.

[142] W. Koppenol, J. Moreno, W.A. Pryor, H. Ischiropoulos, J. Beckman, Chemical research in toxicology 5 (1992) 834-842.

[143] S.x. Chen, P. Schopfer, European Journal of Biochemistry 260 (1999) 726-735.

[144] A. Gomes, L. Asad, I. Felzenszwalb, A. Leitão, A. Silva, H. Guillobel, N. Asad, Radiation and environmental biophysics 43 (2004) 219-222.

[145] R.L. Knowles, A. Eisenstark, Environmental health perspectives 102 (1994) 88.

[146] S. Basu-Modak, R.M. Tyrrell, Cancer research 53 (1993) 4505-4510.

[147] R.M. TYRRELL, M. PIDOUX, Photochemistry and photobiology 49 (1989) 407-412.

[148] R.M. Tyrrell, C.A. Pourzand, J. Brown, V. Hejmadi, V. Kvam, S. Ryter, R. Watkin, Radiation protection dosimetry 91 (2000) 37-39.

[149] R.L. Levine, Free Radical Biology and Medicine 32 (2002) 790-796.

[150] D. Touati, Archives of biochemistry and biophysics 373 (2000) 1-6.

[151] A. Bagg, J. Neilands, Microbiological reviews 51 (1987) 509.

[152] J.H. Crosa, Microbiological Reviews 53 (1989) 517-530.

[153] K. Hantke, FEMS microbiology letters 44 (1987) 53-57.

[154] B. Morgan, O. Lahav, Chemosphere 68 (2007) 2080-2084.

[155] V. Braun, International journal of medical microbiology 291 (2001) 67-79.

[156] A.J. Hudson, S.C. Andrews, C. Hawkins, J.M. Williams, M. Izuhara, F.C. Meldrum, S. Mann, P.M. Harrison, J.R. Guest, European Journal of Biochemistry 218 (1993) 985-995.

[157] K. Keyer, J.A. Imlay, Proceedings of the National Academy of Sciences 93 (1996) 13635-13640.

[158] J. Yariv, A. Kalb, R. Sperling, E. Bauminger, S. Cohen, S. Ofer, Biochemical Journal 197 (1981) 171-175.

[159] B. Halliwell, J. Gutteridge, Biochemical journal 219 (1984) 1.

[160] S.D. Aust, L.A. Morehouse, C.E. Thomas, Journal of free radicals in biology \& medicine 1 (1985) 3-25.

[161] P. Biemond, A. Swaak, C.M. Beindorff, J.F. Koster, Biochemical Journal 239 (1986) 169-173.

[162] P. Biemond, A.J. Swaak, H.G. van Eijk, J.F. Koster, Free Radical Biology and Medicine 4 (1988) 185-198.

[163] J.A. Imlay, Molecular microbiology 59 (2006) 1073-1082.

[164] S. Jang, J.A. Imlay, Journal of Biological Chemistry 282 (2007) 929-937.

[165] S. Varghese, Y. Tang, J.A. Imlay, Journal of bacteriology 185 (2003) 221-230.

[166] L. Kelland, S. Moss, D. Davies, Photochemistry and photobiology 37 (1983) 617-622.

[167] J. Cadet, S. Mouret, J.L. Ravanat, T. Douki, Photochemistry and photobiology 88 (2012) 10481065. 

Sciences 96 (1999) 6751-6756.

1438 [169] J. Cadet, M. Berger, T. Douki, J.-L. Ravanat, Reviews of Physiology Biochemistry and Pharmacology, Volume 131, Springer, 1997, pp. 1-87.

1440 [170] D.R. Lloyd, D.H. Phillips, P.L. Carmichael, Chemical research in toxicology 10 (1997) 393-400.

1441

1442

1443

1444

[171] K. Randerath, E. Randerath, C.V. Smith, J. Chang, Chemical research in toxicology 9 (1996) 247254.

[172] J.L. Farber, Environmental health perspectives 102 (1994) 17.

[173] G.W. Teebor, R.J. Boorstein, J. Cadet, International journal of radiation biology 54 (1988) 131150.

[174] W.K. Pogozelski, T.D. Tullius, Chemical reviews 98 (1998) 1089-1108.

[175] J. Cadet, J.L. Ravanat, G.R. Martinez, M.H. Medeiros, P.D. Mascio, Photochemistry and photobiology 82 (2006) 1219-1225.

[176] F. Hutchinson, Progress in nucleic acid research and molecular biology 32 (1985) 115-154.

[177] J.A. Imlay, Current opinion in microbiology 24 (2015) 124-131.

[178] E. Bourdon, D. Blache, Antioxidants and Redox Signaling 3 (2001) 293-311.

[179] H.-R. Shen, J.D. Spikes, C.J. Smith, J. Kopeček, Journal of Photochemistry and Photobiology A: Chemistry 133 (2000) 115-122.

1454 [180] F. Bosshard, K. Riedel, T. Schneider, C. Geiser, M. Bucheli, T. Egli, Environmental microbiology $145512(2010)$ 2931-2945.

1456 [181] E. Cabiscol, J. Tamarit, J. Ros, International Microbiology 3 (2010) 3-8.

1457 [182] F. Chiti, Protein Misfolding, Aggregation, and Conformational Diseases, Springer, 2006, pp. 43145859.

1459 [183] L. Fucci, C.N. Oliver, M.J. Coon, E.R. Stadtman, Proceedings of the National Academy of 1460 Sciences $80(1983)$ 1521-1525.

1461 [184] T. Grune, T. Jung, K. Merker, K.J. Davies, The international journal of biochemistry \& cell 1462 biology 36 (2004) 2519-2530.

1463 [185] T.C. Squier, Experimental gerontology 36 (2001) 1539-1550.

1464 [186] E.R. Stadtman, Free Radical Biology and Medicine 9 (1990) 315-325.

1465 [187] Y.-J. Rang, J.D. Spikes, Archives of biochemistry and biophysics 172 (1976) 565-573.

1466 [188] E. Silva, C. De Landea, A.M.a. Edwards, E. Lissi, Journal of Photochemistry and Photobiology B: 1467 Biology 55 (2000) 196-200.

1468 [189] R. Pizarro, International journal of radiation biology 68 (1995) 293-299.

1469 [190] P.E. Morgan, R.T. Dean, M.J. Davies, Free Radical Biology and Medicine 36 (2004) 484-496.

1470 [191] C. Luxford, R.T. Dean, M.J. Davies, Chemical research in toxicology 13 (2000) 665-672.

1471 [192] K.B. Choksi, J. Papaconstantinou, Free Radical Biology and Medicine 44 (2008) 1795-1805.

1472 [193] R. Venkatadri, R.W. Peters, Hazardous Waste and Hazardous Materials 10 (1993) 107-149.

1473 [194] J.A. Imlay, Annual Review of Biochemistry 77 (2008) 755-776.

1474 [195] L.C. Seaver, J.A. Imlay, Journal of bacteriology 183 (2001) 7182-7189.

1475 [196] E. Cadenas, K.J. Davies, Free Radical Biology and Medicine 29 (2000) 222-230.

1476 [197] C. Sichel, P. Fernández-lbáñez, M. de Cara, J. Tello, Water research 43 (2009) 1841-1850.

1477 [198] J.A. Imlay, S. Linn, Journal of Bacteriology 166 (1986) 519-527.

1478 [199] L. Uhl, A. Gerstel, M. Chabalier, S. Dukan, Heliyon 1 (2015) Article e00049.

1479 [200] B. Halliwell, O.I. Aruoma, FEBS letters 281 (1991) 9-19.

1480 [201] S. Park, X. You, J.A. Imlay, Proceedings of the National Academy of Sciences of the United 1481 States of America 102 (2005) 9317-9322.

1482 [202] S.I. Liochev, I. Fridovich, Free Radical Biology and Medicine 16 (1994) 29-33.

1483 [203] D. Touati, M. Jacques, B. Tardat, L. Bouchard, S. Despied, Journal of bacteriology 177 (1995) $1484 \quad 2305-2314$.

1485 [204] B. Halliwell, J. Gutteridge, FEBS letters 307 (1992) 108-112.

1486 [205] J. Rush, Z. Maskos, W. Koppenol, FEBS letters 261 (1990) 121-123. 

Mutagenesis 72 (1980) 31-42.

[212] C. Keenan, Massachusetts Institute of Technology, Cambridge MA, USA (2001).

[213] R. Khaengraeng, R. Reed, Journal of applied microbiology 99 (2005) 39-50.

[214] T.W. Ng, T. An, G. Li, W.K. Ho, H.Y. Yip, H. Zhao, P.K. Wong, Journal of Photochemistry and Photobiology B: Biology 149 (2015) 164-171.

[215] M.B. Fisher, K.L. Nelson, Applied and environmental microbiology 80 (2014) 935-942.

[216] A.D. Bokare, W. Choi, Journal of hazardous materials 275 (2014) 121-135.

[217] J. Pierre, M. Fontecave, R. Crichton, Biometals 15 (2002) 341-346.

1501

1502

1503

1504

[218] C. Wang, H. Liu, Z. Sun, International Journal of Photoenergy 2012 (2012).

[219] S.R. Pouran, A.A.A. Raman, W.M.A.W. Daud, Journal of Cleaner Production 64 (2014) 24-35.

[220] J. De Laat, H. Gallard, Environmental Science \& Technology 33 (1999) 2726-2732.

[221] W. Sung, J.J. Morgan, Environmental Science \& Technology 14 (1980) 561-568.

[222] L. Demarchis, M. Minella, R. Nisticò, V. Maurino, C. Minero, D. Vione, Journal of Photochemistry and Photobiology A: Chemistry 307 (2015) 99-107.

1507 [223] H. Bataineh, O. Pestovsky, A. Bakac, Chemical Science 3 (2012) 1594-1599.

1508 [224] J. Gomis, R. Vercher, A. Amat, D. Mártire, M. González, A.B. Prevot, E. Montoneri, A. Arques, 1509 L. Carlos, Catalysis today 209 (2013) 176-180.

1510 [225] C. Minero, M. Lucchiari, V. Maurino, D. Vione, Rsc Advances 3 (2013) 26443-26450.

1511 [226] S.H. Lin, C.C. Lo, Water research 31 (1997) 2050-2056.

1512 [227] E. Neyens, J. Baeyens, Journal of hazardous materials 98 (2003) 33-50.

1513 [228] R.M. Cornell, U. Schwertmann, The iron oxides: structure, properties, reactions, occurrences 1514 and uses, John Wiley \& Sons, 2006.

1515 [229] J.P. Jolivet, C. Chanéac, E. Tronc, Chemical Communications 10 (2004) 481-487.

1516 [230] S.M. Kraemer, Aquatic sciences 66 (2004) 3-18.

1517 [231] W.Y. Guohua, Zhao; Hongying, Zhao; Xiuchun, Wang; Yujing, Yang, Progress in Chemistry 8 1518 (2013) 003.

1519 [232] W. Feng, D. Nansheng, Chemosphere 41 (2000) 1137-1147.

1520 [233] J.K. Leland, A.J. Bard, Journal of Physical Chemistry 91 (1987) 5076-5083.

1521 [234] F. Millero, WATER SCIENCE AND TECHNOLOGY LIBRARY 25 (1997) 381-398.

1522 [235] W. Stumm, B. Sulzberger, Geochimica et Cosmochimica Acta 56 (1992) 3233-3257.

1523 [236] Y. Deng, W. Stumm, Applied Geochemistry 9 (1994) 23-36.

1524 [237] G.J. Jones, B.P. Palenik, F.M. Morel, Journal of Phycology 23 (1987) 237-244.

1525 [238] D.W. King, Environmental science \& technology 32 (1998) 2997-3003.

1526 [239] W.L. Miller, R.G. Zepp, Geophysical Research Letters 22 (1995) 417-420.

1527 [240] B.M. Voelker, D.L. Sedlak, Marine Chemistry 50 (1995) 93-102.

1528 [241] B.M. Voelker, B. Sulzberger, Environmental Science \& Technology 30 (1996) 1106-1114.

1529 [242] T.D. Waite, F.M. Morel, Environmental science \& technology 18 (1984) 860-868.

1530 [243] B.C. Faust, R.G. Zepp, Environmental Science \& Technology 27 (1993) 2517-2522.

1531 [244] T. Fox, N. Comerford, Soil Science Society of America Journal 54 (1990) 1139-1144.

1532 [245] D. Grosjean, K. Van Cauwenberghe, J.P. Schmid, P.E. Kelley, J.N. Pitts Jr, Environmental Science 1533 \& Technology 12 (1978) 313-317.

1534 [246] K. Kawamura, S. Steinberg, I. Kaplan, International journal of environmental analytical 1535 chemistry 19 (1985) 175-188.

1536 [247] W.L. Lamar, D.F. Goerlitz, Organic acids in naturally colored surface waters, USGPO, 1966.

1537 [248] G.E. Likens, E.S. Edgerton, J.N. Galloway, Tellus B 35 (1983) 16-24. 
[249] H. Satsumabayashi, H. Kurita, Y. Yokouchi, H. Ueda, Atmospheric Environment. Part A. General 1539 Topics 24 (1990) 1443-1450.

1540 [250] E.M. Thurman, Organic geochemistry of natural waters, Springer Science \& Business Media, 2012.

1542 [251] G.R. Helz, R.G. Zepp, D.G. Crosby, (1994).

1543 [252] Y. Zuo, J. Hoigne, Environmental Science \& Technology 26 (1992) 1014-1022.

1544 [253] P. Cieśla, P. Kocot, P. Mytych, Z. Stasicka, Journal of Molecular Catalysis A: Chemical 224 (2004)

[270] P.-C. Maness, S. Smolinski, D.M. Blake, Z. Huang, E.J. Wolfrum, W.A. Jacoby, Applied and environmental microbiology 65 (1999) 4094-4098.

[271] C.L. Peacock, D.M. Sherman, Geochimica et Cosmochimica Acta 68 (2004) 2623-2637.

[272] H. Wu, D. Jiang, P. Cai, X. Rong, Q. Huang, Colloids and Surfaces B: Biointerfaces 82 (2011) 147151.

[273] B.M. Voelker, F.M.M. Morel, B. Sulzberger, Environmental Science \& Technology 31 (1997) 1004-1011.

[274] Z. Zhang, C. Boxall, G. Kelsall, Colloids and Surfaces A: Physicochemical and Engineering Aspects 73 (1993) 145-163.

[275] P. Mazellier, M. Bolte, Journal of Photochemistry and Photobiology A: Chemistry 132 (2000) 129-135.

[276] J. Xu, N. Sahai, C.M. Eggleston, M.A. Schoonen, Earth and Planetary Science Letters 363 (2013) 156-167.

[277] M. Brasca, S. Morandi, R. Lodi, A. Tamburini, Journal of applied microbiology 103 (2007) 15161524.

[278] F. Widdel, S. Schnell, S. Heising, A. Ehrenreich, B. Assmus, B. Schink, Nature 362 (1993) 834836.

[279] Y. Xu, M.A. Schoonen, American Mineralogist 85 (2000) 543-556.

[280] V. Buzmakov, A. Pshenichnikov, Journal of colloid and interface science 182 (1996) 63-70. 
[281] R.C. Costa, M. Lelis, L. Oliveira, J. Fabris, J.D. Ardisson, R. Rios, C. Silva, R. Lago, Journal of hazardous materials 129 (2006) 171-178.

1590 [282] I.S. Pinto, P.H. Pacheco, J.V. Coelho, E. Lorençon, J.D. Ardisson, J.D. Fabris, P.P. de Souza, K.W. Krambrock, L.C. Oliveira, M.C. Pereira, Applied Catalysis B: Environmental 119 (2012) 175-182. 215-237.

[284] P.M. Borer, B. Sulzberger, P. Reichard, S.M. Kraemer, Marine Chemistry 93 (2005) 179-193.

[285] S.K. Han, T.-M. Hwang, Y. Yoon, J.-W. Kang, Chemosphere 84 (2011) 1095-1101.

[286] J. He, X. Tao, W. Ma, J. Zhao, Chemistry letters (2002) 86-87.

[287] K.M. Mostofa, C.-q. Liu, M.A. Mottaleb, G. Wan, H. Ogawa, D. Vione, T. Yoshioka, F. Wu, Photobiogeochemistry of Organic Matter, Springer, 2013, pp. 1-137.

[288] K. Mostofa, F. Wu, T. Yoshioka, H. Sakugawa, E. Tanoue, Natural organic matter and its significance in the environment. Science Press, Beijing (2009) 3-66.

[289] R. Benner, J.D. Pakulski, Science 255 (1992) 1561.

[290] K. Isao, S. Hara, K. Terauchi, K. Kogure, Nature 345 (1990) 242-244.

[291] J.H. Sharp, Limnol. Oceanogr 18 (1973) I-447.

[292] R.D. Vold, M.J. Vold, Colloid and interface chemistry, Addison-Wesley, 1983.

[293] M.L. Wells, Biogeochemistry of marine dissolved organic matter (2002) 367-404.

[294] K. Hayase, H. Tsubota, Geochimica et Cosmochimica Acta 49 (1985) 159-163.

[295] X. Ma, N. Ali, Natural organic matter and its significance in the environment. Science Press, Beijing (2009) 66-89.

[296] F. Stevenson, G.R. Aiken, D.M. Mcknight, R.L. Wershaw, P. MacCarthy, eds. Aiken GR, McKnight DM, Wershaw RL, and Maccarthy P, John Wiley \& Sons, New York (1985) 13-52.

[297] A.M. Amado, J.B. Cotner, A.L. Suhett, F.d.A. Esteves, R.L. Bozelli, V.F. Farjalla, Aquatic Microbial Ecology 49 (2007) 25-34.

[298] P.G. Coble, Marine chemistry 51 (1996) 325-346.

[299] P.G. Coble, Chemical reviews 107 (2007) 402-418.

[300] K. Mostofa, C. Liu, F. Wu, P. Fu, W. Ying, J. Yuan, Overview of key biogeochemical functions in lake ecosystem: impacts of organic matter pollution and global warming, Proceedings of 13th World Lake Conference, Wuhan, China, 2009, pp. 1-5.

[301] E. Parlanti, K. Wörz, L. Geoffroy, M. Lamotte, Organic Geochemistry 31 (2000) 1765-1781.

[302] Y. Zhang, M.A. van Dijk, M. Liu, G. Zhu, B. Qin, Water research 43 (2009) 4685-4697.

[303] K.R. Arrigo, C.W. Brown, (1996).

[304] N. Nelson, D. Siegel, A. Michaels, Deep Sea Research Part I: Oceanographic Research Papers 45 (1998) 931-957.

[305] N.B. Nelson, C.A. Carlson, D.K. Steinberg, Marine Chemistry 89 (2004) 273-287.

[306] C. Du, S. Shang, Q. Dong, C. Hu, J. Wu, Estuarine, Coastal and Shelf Science 88 (2010) 350-356. [307] J.R. Helms, A. Stubbins, J.D. Ritchie, E.C. Minor, D.J. Kieber, K. Mopper, Limnology and Oceanography 53 (2008) 955-969.

[308] C.J. Hulatt, D.N. Thomas, D.G. Bowers, L. Norman, C. Zhang, Estuarine, Coastal and Shelf Science 84 (2009) 147-153.

[309] E. Rochelle-Newall, T. Fisher, Marine Chemistry 77 (2002) 23-41.

[310] S. Wada, M.N. Aoki, Y. Tsuchiya, T. Sato, H. Shinagawa, T. Hama, Journal of experimental marine biology and ecology 349 (2007) 344-358.

[311] Y. Dudal, R. Holgado, G. Maestri, E. Guillon, L. Dupont, Science of the total environment 354 (2006) 286-291.

[312] A. Manciulea, A. Baker, J.R. Lead, Chemosphere 76 (2009) 1023-1027.

[313] J. Klinck, M. Dunbar, S. Brown, J. Nichols, A. Winter, C. Hughes, R.C. Playle, Aquatic toxicology 72 (2005) 161-175.

[314] M.L. Schwartz, P.J. Curtis, R.C. Playle, Environmental toxicology and chemistry 23 (2004) 28892899. 
1639 [315] A.C. Stenson, A.G. Marshall, W.T. Cooper, Analytical Chemistry 75 (2003) 1275-1284.

1640 [316] A.T. Chow, J. Dai, W.H. Conner, D.R. Hitchcock, J.-J. Wang, Biogeochemistry 112 (2013) 571-

1642 [317] D.M. White, D.S. Garland, J. Narr, C.R. Woolard, Water research 37 (2003) 939-947.

[318] H. Xie, O.C. Zafiriou, W.-J. Cai, R.G. Zepp, Y. Wang, Environmental science \& technology 38 (2004) 4113-4119.

[320] M.L. Estapa, L.M. Mayer, Marine Chemistry 122 (2010) 138-147.

[321] J.R. Helms, D.A. Glinski, R.N. Mead, M.W. Southwell, G.B. Avery, R.J. Kieber, S.A. Skrabal, Organic Geochemistry 73 (2014) 83-89.

[322] R.J. Kieber, R.F. Whitehead, S.A. Skrabal, Limnology and Oceanography 51 (2006) 2187-2195.

[323] L.M. Mayer, L.L. Schick, K. Skorko, E. Boss, Limnology and Oceanography 51 (2006) 1064-1071.

[324] M.W. Southwell, R.J. Kieber, R.N. Mead, G.B. Avery, S.A. Skrabal, Biogeochemistry 98 (2010) $115-126$.

[325] S. Canonica, CHIMIA International Journal for Chemistry 61 (2007) 641-644.

[326] G. McKay, F.L. Rosario-Ortiz, Environmental science \& technology 49 (2015) 4147-4154.

[327] J. Buschmann, S. Canonica, L. Sigg, Environmental science \& technology 39 (2005) 5335-5341.

[328] S. Canonica, M. Freiburghaus, Environmental science \& technology 35 (2001) 690-695.

[329] K.M. Cawley, J.A. Hakala, Y.P. Chin, Limnology and Oceanography: Methods 7 (2009) 391-398. [330] S. Halladja, A. Ter Halle, J.-P. Aguer, A. Boulkamh, C. Richard, Environmental science \& technology 41 (2007) 6066-6073.

1660 [331] L.E. Jacobs, L.K. Weavers, E.F. Houtz, Y.-P. Chin, Chemosphere 86 (2012) 124-129.

1661 [332] P.G. Tratnyek, J. Hoigné, Journal of Photochemistry and Photobiology A: Chemistry 84 (1994) 1662 153-160.

1663 [333] D. Vione, M. Minella, V. Maurino, C. Minero, Chemistry-A European Journal 20 (2014) 10590166410606.

1665 [334] W.J. Cooper, R.G. Zika, Science(Washington) 220 (1983) 711-712.

1666 [335] W.J. Cooper, R.G. Zika, R.G. Petasne, J.M. Plane, Environmental science \& technology 22 1667 (1988) 1156-1160.

1668 [336] W.M. Draper, D.G. Crosby, Archives of Environmental Contamination and Toxicology 12 (1983) 1669 121-126.

1670 [337] N. Scully, D. McQueen, D. Lean, Limnology and Oceanography 41 (1996) 540-548. [338] D.T. Scott, R.L. Runkel, D.M. McKnight, B.M. Voelker, B.A. Kimball, E.R. Carraway, Water resources research 39 (2003).

[339] S.S. Andrews, S. Caron, O.C. Zafiriou, Limnology and Oceanography 45 (2000) 267-277.

[340] J.H. Jerome, R.P. Bukata, Journal of Great Lakes Research 24 (1998) 929-935.

[341] C.A. Moore, C.T. Farmer, R.G. Zika, Journal of Geophysical Research 98 (1993) 2289-2298.

[342] R.J. Sikorski, R.G. Zika, Journal of Geophysical Research 98 (1993) 2315-2328.

[343] B.H. Yocis, D.J. Kieber, K. Mopper, Deep-Sea Research Part I: Oceanographic Research Papers 47 (2000) 1077-1099.

[344] E.M. White, P.P. Vaughan, R.G. Zepp, Aquatic Sciences 65 (2003) 402-414.

[345] D.M. McKnight, B.A. Kimball, R.L. Runkel, Hydrological Processes 15 (2001) 1979-1992.

[346] R.K. Skogerboe, S.A. Wilson, Analytical Chemistry 53 (1981) 228-232.

[347] M. Sanly, K.C. Lim, R. Amal, R. Fabris, C. Chow, M. Drikas, Separation Science and Technology 42 (2007) 1391-1404.

[348] B.A. Southworth, B.M. Voelker, Environmental Science and Technology 37 (2003) 1130-1136. [349] A. Moncayo-Lasso, A.G. Rincon, C. Pulgarin, N. Benitez, Journal of Photochemistry and Photobiology A: Chemistry 229 (2012) 46-52.

[350] N.V. Blough, R.G. Zepp, Active oxygen in chemistry, Springer, 1995, pp. 280-333.

[351] H. Gao, R.G. Zepp, Environmental Science \& Technology 32 (1998) 2940-2946.

[352] H. Tamura, K. Goto, M. Nagayama, Corrosion Science 16 (1976) 197-207. 

Photobiological Sciences 3 (2004) 273-280.

[355] S.L.H. Sandvik, P. Bilski, J.D. Pakulski, C.F. Chignell, R.B. Coffin, Marine Chemistry 69 (2000) 139-152.

[359] R. Del Vecchio, N.V. Blough, Marine Chemistry 78 (2002) 231-253.

[360] R.G. Zepp, UV effects in aquatic organisms and ecosystems. The Royal Society of Chemistry (2003) 137-184.

[361] A. Georgi, A. Schierz, U. Trommler, C.P. Horwitz, T.J. Collins, F.D. Kopinke, Applied Catalysis B: Environmental 72 (2007) 26-36.

[362] S.G. Huling, R.G. Arnold, R.A. Sierka, M.R. Miller, Water research 35 (2001) 1687-1694.

[363] J. Kochany, E. Lipczynska-Kochany, Environmental Technology 28 (2007) 1007-1013.

[364] C. Kuei-Jyum Yeh, Y.A. Kao, C.P. Cheng, Chemosphere 46 (2002) 67-73.

[365] E. Lipczynska-Kochany, J. Kochany, Chemosphere 73 (2008) 745-750.

[366] C.A. Murray, S.A. Parsons, Chemosphere 54 (2004) 1017-1023.

[367] D. Spuhler, J.A. Rengifo-Herrera, C. Pulgarin, Applied catalysis. B, Environmental 96 (2010) 126-141.

[368] A.W. Vermilyea, B.M. Voelker, Environmental Science and Technology 43 (2009) 6927-6933.

[369] D. Vione, G. Falletti, V. Maurino, C. Minero, E. Pelizzetti, M. Malandrino, R. Ajassa, R.I. Olariu, C. Arsene, Environmental Science and Technology 40 (2006) 3775-3781.

1713 [370] D. Vione, F. Merlo, V. Maurino, C. Minero, Environmental Chemistry Letters 2 (2004) 129-133.

1714 [371] G.K.B. Lopes, H.M. Schulman, M. Hermes-Lima, Biochimica et Biophysica Acta - General 1715 Subjects 1472 (1999) 142-152.

1716 [372] C. Tixier, H.P. Singer, S. Canonica, S.R. Müller, Environmental Science and Technology 36 $1717 \quad$ (2002) 3482-3489.

1718 [373] B.W. Bogan, V. Trbovic, Journal of hazardous materials 100 (2003) 285-300.

1719 [374] M.E. Lindsey, M.A. Tarr, Environmental Science and Technology 34 (2000) 444-449.

1720 [375] M.E. Lindsey, M.A. Tarr, Chemosphere 41 (2000) 409-417.

1721 [376] L.L. Bissey, J.L. Smith, R.J. Watts, Water research 40 (2006) 2477-2484.

1722 [377] Z.M. Li, P.J. Shea, S.D. Comfort, Chemosphere 36 (1998) 1849-1865.

1723 [378] B.W. Tyre, R.J. Watts, G.C. Miller, Journal of Environmental Quality 20 (1991) 832-838.

1724 [379] T.W. Ng, A.T. Chow, P.K. Wong, Journal of Photochemistry and Photobiology A: Chemistry 290 1725 (2014) 116-124.

1726 [380] J.J. Guerard, P.L. Miller, T.D. Trouts, Y.P. Chin, Aquatic Sciences 71 (2009) 160-169.

1727 [381] J. Wenk, U. von Gunten, S. Canonica, Environmental Science \& Technology 45 (2011) 1334-

[382] M.F. Budyka, M.V. Alfimov, Russian Chemical Reviews 64 (1995) 705-717.

[383] M. Roca, J. Zahardis, J. Bone, M. El-Maazawi, V.H. Grassian, Journal of Physical Chemistry A 112 (2008) 13275-13281.

[384] R.G. Zepp, J. Hoigné, H. Bader, Environmental Science and Technology 21 (1987) 443-450.

[385] P. Warneck, C. Wurzinger, Journal of Physical Chemistry 92 (1988) 6278-6283.

[386] H.Y. Chen, O. Zahraa, M. Bouchy, Journal of Photochemistry and Photobiology A: Chemistry 108 (1997) 37-44.

[387] J.E. Grebel, J.J. Pignatello, W.A. Mitch, Environmental science \& technology 44 (2010) 68226828.

1738 [388] C.-H. Liao, S.-F. Kang, F.-A. Wu, Chemosphere 44 (2001) 1193-1200. 